WORKING PAPER \#402

PRINCETON UNIVERSITY

INDUSTRIAL RELATIONS SECTION

July, 1998

\title{
Recent Trends in Employer-Sponsored Health Insurance Coverage: Are Bad Jobs Getting Worse?
}

\author{
by \\ Henry S. Farber ${ }^{*}$ \\ Princeton University \\ and \\ Helen Levy \\ Robert Wood Johnson Scholars in Health Policy Program \\ University of California--Berkeley
}

July 17,1998

\begin{abstract}
We examine whether the decline in the availability of employer-provided health insurance is a phenomenon common to all jobs or is concentrated only on certain jobs. In particular, we investigate the extent to which employers have continued to provide health insurance on what we term "core" jobs while reducing the availability of health insurance on "peripheral" jobs. We consider two dimensions on which jobs may be considered peripheral: if they are new (tenure less than one year) or part-time. We consider three outcomes whose product is the health insurance coverage rate: 1) the fraction of worker who are in firms that offer health insurance to at least some workers (the offer rate); 2) the fraction of workers who are eligible for health insurance, conditional on being in a firm where it is offered (the eligibility rate); and 3) the fraction of workers who enroll in health insurance when they are eligible for it (the takeup rate). We find that declines in own-employer insurance coverage over the 1988-1997 period are driven primarily by declines in takeup for core workers and declines in eligibility for peripheral workers. We also look at trends by workers' education level, and see how much of the decline in is offset by an increase in coverage through a spouse's policy. Our findings are consistent with the view that employers are continuing to make health insurance available to their core long-term, full-time employees but are restricting access to health insurance by their peripheral short-term and part-time employees.
\end{abstract}

\footnotetext{
* Address correspondence to: Henry Farber, Industrial Relations Section, Firestone Library, Princeton University, Princeton NJ 08544; farber@princeton.edu.
} 


\title{
Recent Trends in Employer-Sponsored Health Insurance Coverage: Are Bad Jobs Getting Worse?*
}

\author{
Henry S. Farber and Helen Levy
}

\section{Introduction}

The central goal of this study is to investigate the decline in the availability of employerprovided health insurance in the context of an examination of the quality of jobs. Our interest in this issue is motivated both by concern about declining availability of employer-sponsored health insurance and by more general concern about declining job quality in the United States. ${ }^{1}$

In order to shed some light on these issues, we examine whether the decline in the availability of employer-provided health insurance is a phenomenon common to all jobs or is concentrated only on certain jobs. In particular, we investigate the extent to which employers have continued to provide health insurance on what we term "core" jobs while reducing the availability of health insurance on "peripheral" jobs. What we mean to capture by this concept of "core" jobs are longterm full time jobs that form the core of the U.S. labor market. We operationalize the concept of core and peripheral jobs using information about job tenure and usual weekly hours of work. We classify jobs as either old or new, where new jobs are defined for our purposes as jobs that workers have started only recently. ${ }^{2}$ We also classify jobs as full time (usual hours of work greater than 35 per week) or part-time. These distinctions result in four categories of jobs: old full-time, new full-time, old part-time and new part-time. The first category (old full-time jobs) are what we consider "core" jobs; all the others are "peripheral" according to our definition. We

\footnotetext{
* We thank David Cutler, Michael Gibbs, Doug Staiger, participants in the 1998 American Compensation Association Academic Research Conference and participants in the Princeton University labor lunch for helpful comments. Farber thanks the AARP for financial support of an earlier version of this work.

1 Important contributors to the literature on changes in job quality include Bluestone and Harrison $(1986,1988)$, Kosters and Ross (1988), Costrell (1990), and Houseman (1995). See Cutler and Gruber (1995), Fronstin and Snider (1996/97), Shore-Sheppard (1996) Krueger and Levy (1997), Schone and Cooper (1997), and Levy (1998) for evidence of a gradual decline in rates of coverage by employer-sponsored health insurance throughout the 1980s and 1990s.
}

2 The rationale for this definition of new jobs is discussed in detail in Farber (1997). While there is not a perfect correspondence between jobs with low tenure and jobs that are destined to be short-term (after all, long term jobs have to start somewhere) it is clear that workers in short-term jobs, and therefore peripheral workers, are overrepresented among workers with less tenure. 
also examine trends in health insurance coverage by workers' education level to determine whether recent changes have disproportionately affected less-skilled workers.

We begin our analysis by comparing trends in health insurance coverage in the public and private sectors from 1979 to 1997 using data from the Current Population Survey (CPS). We find that health insurance coverage in the public sector is relatively stable over the period we examine (1979-1997), but that health insurance coverage rates in the private sector declined from 71.9 percent in 1979 to 64.5 percent in 1997. Next, we compare coverage rates for different types of workers in the private sector. We find that throughout this period, workers on peripheral jobs have been less likely than workers on core (long-term full-time) jobs to have health insurance. This differential will help explain the overall decline in employer-sponsored health insurance coverage if either 1) the fraction of workers in peripheral jobs is increasing or 2) the core/peripheral differential in coverage is increasing over time.

We document that within the private sector, declines in coverage have been particularly sharp for workers on new jobs (both full and part-time). We also find that the fraction of jobs that are new or part-time has not risen substantially over the 1979-1997 period, in both the public and private sectors. Therefore, to the extent that the core/peripheral differential helps explain the decline in coverage, it is because the gap between the two types of workers has widened and not because the distribution of employment has changed.

These preliminary findings lead us to ask several additional questions about the mechanisms through which access to health insurance is restricted. We examine three intermediate measures of access to health insurance: 1) the fraction of workers who are in firms that offer health insurance to at least some workers (the offer rate); 2) the fraction of workers who are eligible for health insurance, conditional on being in a firm where it is offered (the eligibility rate); and 3) the fraction of workers who enroll in health insurance when they are eligible for it (the takeup rate). The product of these three rates is the rate of coverage by employer-sponsored health insurance. We focus on each of them in turn in order to understand the decline in health insurance coverage overall and also within each group of workers.

We proceed by using establishment-level data to analyze how often employers change their health insurance offering behavior, either dropping or adding benefits. Our results show that in 1993 about one-tenth of all workers were in establishments that had either dropped or added 
health benefits during the past five years. We then return to the CPS data and conduct a more detailed analysis that examines changes in health insurance offering, eligibility, and takeup. This analysis reveals that the factors driving the declines in coverage for core workers are quite different from those affecting peripheral workers. Among core workers, a decline in takeup accounts for nearly all of the decline in coverage, while for part-time workers on old or new jobs all of the decline in coverage is due to a decline in eligibility. Takeup and eligibility declines are approximately equally responsible for the coverage decline for new full-time workers. Thus, the evidence is consistent with the view that (1) employers are continuing to make health insurance available to their core long-term, full-time employees but are restricting access to health insurance by their peripheral short-term and part-time employees and (2) core workers may be less likely to demand insurance coverage from their employers than they have been in the past. These conclusions are reinforced when we consider whether these trends have been offset for at least some workers by changes in the rate of "spousal coverage." That is, workers may have become less likely to have health insurance on their own job, but more likely to be covered as a dependent on a spouse's policy. We find that an increase in the rate of coverage as a dependent offsets approximately one-third of the decline in own-job coverage and that this offset occurred primarily for workers in core jobs.

We also perform similar analyses for workers in four different educational categories (less than high school, high school graduate, some college, and four years of college or more), for all jobs and also looking at core and peripheral jobs separately. Among peripheral jobs, declines in coverage and eligibility occurred across the board, so that workers with four years of college or more experienced a drop in coverage of the same magnitude as that experienced by workers with less than a high school education (approximately six and a half percentage points). The story is quite different for core jobs, where the least-educated workers experienced the largest decline in coverage, driven primarily by a decline in offering and the absence of any offsetting effect from an increase in spousal coverage. Offering rates for more highly educated workers remained stable, and spousal coverage rates increased. Declines in the takeup rate were similar across educational groups for core workers (about four percentage points), and eligibility changed very little for core workers at all levels of education. Thus, while education served as a buffer against coverage declines for core workers, for peripheral workers it did not. Our analysis of trends in 
employer-sponsored health insurance coverage leads us to conclude that the quality of core and peripheral jobs in this dimension is diverging.

\section{Trends in Health Insurance Coverage}

We begin by using data from the Current Population Survey to look at health insurance coverage rates. The four benefit supplements to the CPS (May 1979, May 1983, May 1988, and April 1993) and the two Contingent and Alternative Employment Arrangement Supplements (February 1995 and February 1997) contain information on employer-provided health insurance. In this section, we establish that coverage by employer-provided health insurance has been declining, which is consistent with the results of other studies (see note 1 above). Additionally, we establish that workers on peripheral jobs are less likely to be covered by health insurance provided by their employer and that this gap has grown over time. Due to data limitations, we do not consider the financing of employer-provided health insurance in terms of whether or not the worker contributes to the premium, although there is some evidence that another change has been an increase in employee contributions to employer-provided health insurance (Levy, 1998; Blostin and Pfuntner, 1998). ${ }^{3}$

\section{Trends in the Overall Coverage Rate by Sector}

We first examine the trends in coverage by employer-provided health insurance separately for private and public sector workers. Table 1 contains a breakdown by year in coverage by employer-provided health insurance between May 1979 and February 1997. The results are clear. Public sector workers are substantially more likely to be covered by health insurance provided by their employer (average over the 1979-97 period of 80.9 percent in the public sector and 67.8 percent in the private sector). Additionally, the public-private differential in health insurance coverage has been increasing. The differential was 7.6 percentage points in May 1979 and increased to 16.3 percentage points by February 1997. This reflects entirely a decline in coverage

\footnotetext{
3 From a theoretical perspective, it may not be meaningful to consider who pays because wages are expected to adjust downward to offset the value of employer-provided fringe benefits. However, the evidence on this is weak.
} 
in the private sector from 71.9 percent in May 1979 to 64.5 percent by February 1997. In contrast, the coverage rate in the public sector increased slightly from 79.6 percent in May 1979 to 80.8 percent in February 1997.

Column 5 of table 1 contains regression-adjusted differences in coverage rates between private and public sector workers. These are computed using separate linear probability models (OLS regressions) for each survey year to control for observable worker demographic characteristics (age, sex, race, marital status, the interaction of sex and marital status, and education). The reported estimates are the coefficients on a public sector indicator variable from each survey-year regression. These regression-adjusted estimates are slightly smaller in magnitude than the simple differences in raw means contained in column 4 , but the differential persists even when controlling for these other factors, implying that most of the public-private differential in health insurance coverage rates is not accounted for by worker characteristics. The regression-adjusted estimates confirm that the public-private differential in health insurance coverage rates increased substantially between 1979 and 1997, reflecting the sharp decline in coverage rates on private sector jobs. While the public sector makes up a substantial fraction of employment (19.8 percent in May 1979 declining to 18.1 percent in February 1997), it is clear that the decline in coverage by employer-provided health insurance is strictly a private-sector phenomenon. On this basis, we proceed with our analysis of coverage using only private sector workers.

\section{The Coverage Rate by Type of Job for Private Sector Workers}

We start with an analysis of coverage by employer-provided health insurance for privatesector workers by type of job. Column 1 of table 2 contains the mean coverage rate at each survey date for all private sector workers. Columns 2 and 3 present the average coverage rate for private sector workers in core and peripheral jobs, respectively. Columns 4, 5 and 6 present average coverage rates separately for each of the three types of peripheral jobs (full-time new, part-time old and part-time new); the entry in column 3 for all peripheral jobs is therefore a weighted average of these three columns. Considering all private sector jobs, the health insurance coverage rate fell by 7.4 percentage points (from 71.9 percent in May 1979 to 64.5 in February 
1997). ${ }^{4}$ Coverage is highest on core jobs (80.1 percent on average during the period we examine) and lowest on new part-time jobs (9.5 percent), with new full-time and old part-time jobs in between with coverage rates of 50.7 percent and 28.8 percent, respectively. There was a 5.8 percentage point decline in the coverage rate on core jobs (from 82.8 percent to 77.0 percent), with most of that decline occurring between 1988 and 1993. In contrast, the decline in the coverage rate on new full-time jobs was 14.5 percentage points (from 60.4 percent to 45.9 percent), approximately zero on new part-time jobs, and 3.6 percentage points on new part-time jobs. The raw core-peripheral difference in employer-provided health insurance coverage (column 7 of table 2) increased over the period from 37.4 percentage points in 1979 to 44.6 percentage points by 1993; the largest change occurred during the 1979 to 1983 period. The core-peripheral difference then declined slightly to 42.9 percentage points between 1993 and 1997.

Column 8 of table 2 contains regression-adjusted differences in coverage rates between core and peripheral workers, calculated similarly to those presented in table 1 for public and private sector workers. The differences are computed using separate linear probability models (OLS regressions) for each survey year to control for observable worker demographic characteristics (age, sex, race, marital status, the interaction of sex and marital status, and education). The reported estimates are the coefficients on a peripheral job indicator variable from each surveyyear regression. These regression-adjusted estimates are slightly smaller in magnitude than the simple differences in raw means contained in column 7, but the differential persists even when controlling for these other factors, implying that most of the peripheral-core differential in health insurance coverage rates is not accounted for by worker characteristics. The regression-adjusted estimates confirm that the core-peripheral differential in health insurance coverage rates in the private sector increased substantially between 1979 and 1997.

The effect of the widening core-peripheral differential in coverage on the overall decline in health insurance will be exacerbated by any increase in the fraction of workers in peripheral jobs. Therefore, before proceeding to analyze the separate components of coverage (offering,

4 This is a conservative estimate of the decline. The May 1979 CPS sample includes incorporated self-employed workers (see footnote 8 below), who are less likely to be covered by employer-provided health insurance, so that the figures for May 1979 provide a slightly downward biased estimate (about 0.3 percentage points) of employerprovided health insurance coverage among workers employed by others. 
eligibility, takeup), we analyze whether the fraction of jobs that are new or part-time has changed over time.

\section{The Prevalence of Peripheral Jobs}

\section{The Current Population Survey Data on Job Duration and Usual Hours Worked}

Data on job duration are available from a number of supplements to the CPS. ${ }^{5}$ In this section, where we investigate the incidence of new jobs and part-time jobs, we use data from the mobility supplements to the January 1983, 1987, and 1991, and February 1996 CPS's, from the pension and benefit supplements to the May 1979, May 1983, May 1988, and April 1993 CPS's, and from the February 1995 and 1997 Contingent and Alternative Employment Arrangement Supplements (CAEAS's) to the CPS. These ten surveys span the 18 -year period from 1979 to 1997.

For the purposes of this analysis, we need to identify new jobs, and we classify those workers who report being with their current employer for less than one year as being in new jobs. In all supplements prior to 1994 there is a specific code assigned to workers who have been with their current employer less than one year. ${ }^{6}$ All supplements since 1994 (February 1995, February 1996, and February 1997) code reported job duration in whatever time units the respondent wishes, and workers are classified as being in new jobs based on this information. To identify part-time workers, we use responses to the question "How many hours per week does usually work at this job?" and classify a worker as part-time if the response is 35 hours or less. ${ }^{7}$

5 CPS data on job duration are discussed in more detail in Farber (1997).

6 The mobility supplements through 1991 record information on job duration in months for workers with job duration less than one year. The pension and benefit supplements indicate only that the job duration was less than one year.

7 Data are available on usual weekly hours for half the CPS sample (months in survey 3, 4, 7 and 8) in May 1979, May 1983, May 1988 and April 1993; for one-quarter of the sample (months in survey 4 and 8) in January 1983, January 1987 and January 1991; and for the full sample in February 1995, February 1996 and February 1997. Table 3 shows raw sample sizes with non-missing data. 


\section{Variation in the Prevalence of Peripheral Jobs}

Earlier analysis (Farber, 1998) suggests that neither the fraction of all jobs that were short nor the fraction of jobs that were longer than some arbitrary length (greater than ten years and greater than twenty years) had changed systematically between 1973 and 1993 . Because the focus here is on core and peripheral jobs in the private sector, we perform an analysis of the fraction of jobs that are less than one year old and the fraction of jobs that are part-time in the private sector over the period from 1979 through 1997. Column 1 of table 3 tabulates the fraction of private sector workers aged 20-64 in each CPS supplement with tenure data who have worked for their present employer for less than one year. These fractions are computed using counts weighted by the CPS final sampling weights and exclude self-employed workers. ${ }^{8}$

The fraction of workers in new jobs averages 20.5 percent over the period covered, and moves cyclically in the sense that new-job rates tend to be higher in tight labor markets (1979, 1987-88, 1996-97). ${ }^{9}$ This cyclicality of the new-job rate is not surprising given the fact that new hiring in an expansion implies that there will be an increase in employment at low-tenure levels. Additionally, to the extent that layoffs are concentrated among low-tenure workers, there will be a decrease in employment at low tenure levels in slack labor markets (Abraham and Medoff, 1984; Farber, 1993). While it is difficult to separate secular changes from cyclical movements in a relatively short time series, there is no evidence of a systematic increase in the incidence of new jobs over the 1979-1997 period.

Column two of table 3 contains the part-time rate by year for the private sector. It is clear from these tabulations that the part-time rate is substantially lower in 1979 than in later years. Additionally, there seems to be a weak cyclical pattern to the part-time employment rate with

8 In the May 1979 CPS it is not possible to distinguish the incorporated self-employed from private sector employees. Thus, the May 1979 sample includes the incorporated self-employed. Exploratory analysis using later years data suggests that including the incorporated self-employed in May 1979 has only a modest effect on variables of interest. The incorporated self-employed are only about three percent of employment. In later years, the fraction in new jobs (jobs less than one year old) in the private sector is about 0.5 percentage points lower if the incorporated self-employed are included. The fraction covered by employer provided health insurance is about 0.3 percentage points lower if the incorporated self-employed are included. We could not take the opposite approach of including the incorporated self-employed throughout because no information on health insurance is available for self-employed workers in the February 1995 and 1997 CPS's.

9 Standard errors for these fractions are on the order of 0.25 percent so that differences of 0.7 percent are statistically significant at the 0.05 level. 
relatively low rates of part-time employment in periods with a tight labor market $(1979,1988$, 1996) and relatively high rates part-time rates in periods with a slack labor market (1983, 19911993). But temporal fluctuations are small and are generally not statistically significant. The obvious exception is the significant increase in the part-time rate between May 1979 (the lowest in the sample) and January 1983 (the highest in the sample).

Columns 3 through 6 of table 3 present the distribution of private-sector employment across type of job associated with the probabilities presented in the first two columns of table 3 . Peripheral workers are a substantial fraction of the workforce-about 30 percent of all workersand this fraction has not changed over the period we examine. Thus, an increased incidence of peripheral employment cannot account for any of the decline in coverage by employer-provided health insurance.

We therefore proceed to our analysis of exactly which elements of coverage are causing the decline in the private sector. As we noted above, coverage by employer-provided health insurance is the result of a sequence of steps: 1) The employer must offer health insurance as a fringe benefit to at least some employees, 2) the employee must be eligible for coverage, and 3) the employee must elect to be covered. We analyze each of these steps in turn. Unfortunately, information on coverage is the only information on health insurance available in the May 1979 and May 1983 benefit supplements so that our analysis is restricted to the 1988-1997 period.

\section{The Offering Rate}

Our analysis of the offer rate proceeds in two stages. First we examine data from a largescale employer survey in order to address the question, how often do firms change their compensation package with regard to health insurance, either adding or dropping coverage? We then turn to an analysis of the CPS data since 1988, using workers' responses to questions about whether their employers offer health insurance to any employees in the firm. 


\section{Do Firms Drop Health Insurance? — Evidence from an Employer Survey}

The data used in this part of the analysis are from a 1993 survey of employers in ten states sponsored by the Robert Wood Johnson Foundation (RWJ). The sample consists of 22,347 private establishments with at least one employee in Colorado, Florida, Minnesota, New Mexico, New York, North Dakota, Oklahoma, Oregon, Vermont or Washington. The survey collected information on a variety of establishment characteristics, including whether or not the establishment offered health insurance and on the details of plan benefits and financing for those establishments that offered health insurance. Cantor, Long and Marquis (1995) describe the survey design; they and also Levy (1998) provide overviews of findings from the survey. These data provide the most comprehensive establishment-level information currently available on the provision of employer-sponsored health insurance. A drawback of this survey is that it is not nationally representative. However, Cantor, Long and Marquis conclude, based on a comparison of characteristics of the RWJ survey states with all 50 states (unemployment rate, earnings, distribution of non-farm workers by industry, health spending per capita, and percent of the population without health insurance) that these ten states "generally reflect the pattern of employer health benefits nationally."

Although there are, as we have already noted, a number of studies analyzing the decline in both worker access to and worker coverage by employer-sponsored health insurance, to our knowledge no one has investigated thoroughly the dynamics of health insurance offering from the perspective of the firm. That is, in the existing literature, any fluctuations in offering, eligibility, and/or enrollment may be entirely due to shifts in the distribution of workers across firms that have either always or never offered health insurance. It is impossible to tell from individual-level data like the Current Population Survey whether any firms actually change their health insurance offering behavior over time, either dropping or adding health benefits to the compensation package they offer.

We cannot directly address the question of how much of the decline in employer-sponsored health insurance access and coverage rates is due to changing compensation arrangements offered by firms, rather than to movements of workers across firms with fixed compensation arrangements. However, the RWJ data do allow us to say something about how often employers drop or add health insurance, since the survey asked establishments that did not offer health 
insurance in 1993 whether they had ever in the past five years offered health insurance. The survey also asked establishments that offered health insurance in 1993 when they began offering it. So for this cross-section of establishments, we can say what fraction of workers are in establishments that have always offered health insurance; have started to offer health insurance during the past five years; have stopped offering health insurance at some point in the past five years, or have never offered health insurance in the past five years.

Of the original 22,347 establishments in the RWJ sample, 1,751 of the 15,229 establishments that offered health insurance were missing data on how many years they had offered health insurance, and 105 establishments not offering health insurance were missing data on whether they had ever offered health insurance in the past. These 1,856 observations were dropped from the analysis resulting in the sample of size of 20,491 establishments of which 13,478 offered health insurance.

We use these data to characterize establishments as always offering, never offering, dropping coverage or beginning coverage during the five years prior to the survey. ${ }^{10}$ Most workers $(85$ percent) in 1993 were in establishments that offered health insurance, and most of these (78.6 percent of the total) were in establishments that had offered health insurance for at least the past five years. Of the 15 percent of workers in establishments not offering health insurance, most of them (11.9 percent of the total) were in establishments that had not offered health insurance in the past five years. About one-tenth of all workers were in establishments that had changed their health insurance offering arrangement in the past five years, and these were more likely to be in establishments that had begun offering health insurance (6.4 percent of all workers) than in establishments that had stopped offering health insurance (3.1 percent of the total). While the latter figure is a small fraction of the total, it implies that fully 20 percent of employees in establishments that do not offer health insurance are in establishments that stopped offering health insurance in the last five years.

It is impossible to infer from these numbers whether employers dropping coverage is a significant reason for the observed decline in coverage, since we have no information on how firms have grown or shrunk since changing their compensation packages. We can say, however, 
that at a point in time, relatively few workers are in establishments that have dropped coverage, and about two times that number are in firms that have recently begun offering health insurance.

\section{Have Employers Become Less Likely to Offer Health Insurance? Evidence from the CPS}

The first six columns of table 4 contain mean offering rates (the fraction of workers whose employers offer health insurance to at least some employees) at each survey date (from May 1988 through February 1997) overall and by type of job as in table 2. As with coverage, the offering rate is substantially lower on peripheral jobs than on core jobs (67.2 percent overall on peripheral jobs vs. 88.1 percent overall on core jobs). The overall offering rate actually increased over this period by about a percentage point (from 82.7 percent in May 1988 to 83.5 percent in February 1997). This contrasts with a decline in coverage rates (table 2) of 4.6 percentage points over the same period. Somewhat surprisingly, part-time workers experienced the largest percentage point increases in health insurance offering: offer rates increased from 62.5 percent to 67.5 percent for part-time workers on old jobs, and from 48.0 percent to 56.8 percent for part-time workers on new jobs. Overall, there appears to have been a small decline in the raw core-peripheral differential in offer rates, which decreases from 20.6 percentage points in 1988 to 18.6 percentage points in 1997 (column 7).

The regression-adjusted difference in offering rates are contained in column 8 of table 4, calculated analogously to those in table 2, look very much like the unadjusted differences, implying that most of the core-peripheral differential in offering rates is not accounted for by worker characteristics. These estimates also verify that the core-peripheral differential in health insurance offering rates did not change substantially between 1988 and 1997.

\section{The Eligibility Rate}

Given that coverage rates fell substantially between 1988 and 1997 while offering rates increased, it must be the case that either eligibility rates or takeup rates fell over this period. We

\footnotetext{
10 Among establishments open less than five years, those that had offered health insurance for less than the number of years they had been open were counted as beginning to offer health insurance during this period, while those that had offered it as long as they had been open were counted as always offering.
} 
present an examination of eligibility conditional on offering in table 5. The first six columns of the table contain mean conditional eligibility rates at each survey date overall and by job type. As with coverage and offering, the eligibility rate is substantially lower on peripheral jobs than on core jobs (73.5 percent overall on peripheral jobs vs. 98.2 percent overall on core jobs). The overall eligibility rate fell by 3.1 percentage points (from 94.3 percent in May 1988 to 91.2 percent in February 1997). This reflects a sharp decline in eligibility for all three types of peripheral workers: eligibility declined for part-time workers on old jobs from 78.0 percent to 67.1 percent, for part-time workers on new jobs from 58.6 percent to 35.5 percent, and for fulltime workers on new jobs from 84.1 percent to 78.1 percent. Core workers, by contrast, experienced almost no decline, with an eligibility rate of 99.0 percent in 1988 and 98.2 percent in 1997. These trends imply a substantial increase in the core-peripheral differential in eligibility rates. The unadjusted core-peripheral differential (column 7) rose by 9.6 percentage points (from 19.1 percentage points to 28.7 percentage points), while the regression adjusted differential (column 8) rose by 8.7 percentage points (from 18.1 percentage points to 26.8 percentage points). The substantial decrease in eligibility for workers on new jobs may signal an increase in employers' use of "waiting periods" before an employee becomes eligible for coverage by the employer's plan, while the increases in ineligibility for part-time workers may indicate that employers are simply excluding all part-time workers from eligibility for coverage.

\section{The Takeup Rate}

Table 6 contains estimates of takeup rates (the fraction of eligible workers who choose to be covered by health insurance provided by their employer). The overall takeup rate appears to have declined only slightly over this period, from 88.6 percent in 1988 to 85.0 percent in 1997 . This masks different trends in takeup rates by type of job, however: takeup rates on core jobs, which throughout this period are about 19 percentage points higher than takeup rates on peripheral jobs, declined from 92.6 percent to 88.3 percent. Full-time new jobs had a similar decline, from 82.7 percent to 77.9 percent. Part-time workers, however, increased the rate at which they enrolled in

health insurance: takeup rates for old part-time workers remained approximately constant at about sixty percent, while the takeup rate for new part-time workers increased from 35.3 percent 
to 44.0 percent between 1988 and 1997 . The result is very little change in the core-peripheral differential, either unadjusted (column 7) or regression-adjusted (column 8).

\section{Decomposing the Decline in Health Insurance Coverage}

Our analysis so far has focused on trends in three components of health insurance coverage offering, eligibility, and takeup - for four groups of jobs (old full-time, new full-time, old parttime and new part-time). These trends are summarized in table 7, which presents mean rates of health insurance coverage, offering and eligibility by year and employment group for 1988 and 1997 in panels 1 and 2 of the table. The third panel shows the change in each cell from 1988 to 1997.

We would like to be able to say at this point how important each component of coverage is in driving the overall trend in coverage. In order to do this, recall that the coverage rate in period $t$ (1988 or 1997) is defined as

$$
C_{t}=O_{t} E_{t} T_{t}
$$

where $C_{t}$ is the coverage rate in period t, $O_{t}$ is the offering rate in period t, $E_{t}$ is the eligibility rate conditional on offering in period $\mathrm{t}$, and $T_{t}$ is the takeup rate conditional on offering and eligibility in period t. The change in coverage can be written as

$$
C_{97}-C_{88}=\left(O_{97}-O_{88}\right) E_{88} T_{88}+\left(E_{97}-E_{88}\right) O_{88} T_{88}+\left(T_{97}-T_{88}\right) O_{88} E_{88}+\text { covariance term } 2 .
$$

or in more compact notation as:

$$
\Delta C=\Delta O \cdot E \cdot T+\Delta E \cdot O \cdot T+\Delta T \cdot O \cdot E+\mathrm{cov}
$$


where the first three terms are percentage point changes in the coverage rate due to changes in the offering rate, the eligibility rate, and the takeup rate respectively. ${ }^{11}$ The elements of the decomposition in equation (3) using data for all workers are presented in the far right-hand column of the fourth panel in table 7. A similar decomposition performed separately for each group of workers is presented in the first four columns of the fourth panel of table 7.

The decomposition for all workers shows that declines in takeup rates and declines in eligibility rates contributed equally to the overall decline in coverage. These two factors were offset by an increase in the offer rate that reduced the overall decline in coverage by about eighttenths of a percentage point.

Looking at within-group decompositions reveals that the factors driving the decline in coverage are quite different across job types. The most striking difference is in the role of eligibility. For core workers, the decline in eligibility contributes less than one-fifth of the overall decline in coverage; for new full-time workers, eligibility declines account for more than half of the declines in coverage, and for both old and new part-time workers, eligibility declines are entirely responsible for the decline in coverage, since both offering and takeup for these groups actually increased to offset the decline in eligibility.

Changes in takeup rates were also quite different across job types. Takeup contributed a substantial part of the decline for both old and new full-time workers (3.8 percentage points and 3.1 percentage points, respectively), while it contributed a slight increase for old part-time workers ( 0.3 percentage points) and a substantial increase for new part-time workers $(2.4$ percentage points). Changes in offer rates had little effect on the overall decline in coverage for both old and new full-time workers. For old part-time workers, however, the increase in offer rates offset about half the decline in coverage that would otherwise have occurred. These findings are consistent with our view that employers are maintaining benefits for core workers, while restricting access to these benefits for peripheral workers.

We would also like to be able to assess the contribution of changes in each component for a particular group of workers to the overall decline in coverage; for example, how much did the decline in eligibility for part-time new workers contribute to the overall decline in coverage? In

\footnotetext{
11 The covariance term is $\Delta \mathrm{O} \cdot \Delta \mathrm{E} \cdot \mathrm{T}+\Delta \mathrm{O} \cdot \mathrm{E} \cdot \Delta \mathrm{T}+\mathrm{O} \cdot \Delta \mathrm{E} \cdot \Delta \mathrm{T}+\Delta \mathrm{O} \cdot \Delta \mathrm{E} \cdot \Delta \mathrm{T}$, where $\Delta$ represents the difference between 1988 and 1997 and an unsubscripted term represents the average level in 1988. This term represents the share of the
} 
order to do this, we begin by noting that since the employment shares of the four groups of workers are fairly constant over this period we can write the overall change in each element of coverage as the weighted average of changes for subgroups of workers:

$$
\begin{aligned}
& \Delta O=\alpha_{1} \Delta O_{1}+\alpha_{2} \Delta O_{2}+\alpha_{3} \Delta O_{3}+\alpha_{4} \Delta O_{4} \\
& \Delta E=\alpha_{1} \Delta E_{1}+\alpha_{2} \Delta E_{2}+\alpha_{3} \Delta E_{3}+\alpha_{4} \Delta E_{4} \\
& \Delta T=\alpha_{1} \Delta T_{1}+\alpha_{2} \Delta T_{2}+\alpha_{3} \Delta T_{3}+\alpha_{4} \Delta T_{4}
\end{aligned}
$$

where $\alpha_{i}$ is the employment share and $O_{i}, E_{i}$, and $T_{i}$ are the offering, eligibility and takeup rates for group $i(i=1,2,3,4)$. Substituting each of these expressions into equation (3) yields the following expression:

$$
\begin{aligned}
\Delta C= & \left(\alpha_{1} \Delta O_{1} \cdot E \cdot T+\alpha_{2} \Delta O_{2} \cdot E \cdot T+\alpha_{3} \Delta O_{3} \cdot E \cdot T+\alpha_{4} \Delta O_{4} \cdot E \cdot T\right)+ \\
& \left(\alpha_{1} \Delta E_{1} \cdot O \cdot T+\alpha_{2} \Delta E_{2} \cdot O \cdot T+\alpha_{3} \Delta E_{3} \cdot O \cdot T+\alpha_{4} \Delta E_{4} \cdot O \cdot T\right)+ \\
& \left(\alpha_{1} \Delta T_{1} \cdot O \cdot E+\alpha_{2} \Delta T_{2} \cdot O \cdot E+\alpha_{3} \Delta T_{3} \cdot O \cdot E+\alpha_{4} \Delta T_{4} \cdot O \cdot E\right)+\operatorname{cov}
\end{aligned}
$$

where each element of this expression represents the contribution of a particular group and factor the overall change in coverage. So, for example, the first element of the first row represents the change in coverage attributable to the change in offering for "group 1" workers (however "group 1 " is defined); the second element of the first row represents the change in coverage attributable to the change in offering for "group 2" workers; the first element of the second row represents the change in coverage attributable to the change in eligibility for "group 1" workers, etc.

The final result of these calculations is presented in panel 5 of table 7. Presenting our results this way allows us to see which factors are driving declines in coverage, and several conclusions emerge. The single most important group/factor driving the overall decline in coverage is the decline in takeup for core workers (not surprising since they are by far the largest group of

change in coverage due to the interaction of changes in offering, eligibility and takeup. 
workers, comprising 71.2 percent of total employment). Changes in eligibility for each of the three types of peripheral workers are the next largest factors contributing to the decline, and together explain almost as much of the decline in overall coverage as does takeup for core workers.

To summarize the results we have presented so far: we find that there are declines in coverage for all types of workers. The rate at which workers are offered insurance either did not change or increased over the period 1988 to 1997, while eligibility declined for all types of workers. Take-up rates declined for core workers and new full-time workers, while they increased for both old and new part-time workers. The most important factors contributing to the overall decline in health insurance were the decline in eligibility for peripheral workers and the decline in takeup for core workers.

\section{Two-Worker Couples and Spousal Coverage}

The fact that takeup declines among core workers, which are presumably voluntary, are a substantial factor in the overall decline in coverage leads us to wonder whether some of the coverage decline represents a shift from one source of coverage to another rather than the decision to go without health insurance altogether. So far we have considered only whether workers are covered by group health insurance sponsored by their own employer. A substantial fraction of workers, however, may obtain coverage as dependents on a spouse's employersponsored insurance policy. We hypothesize that some of the declines in coverage from a worker's own employer (referred to as "own coverage") that we have documented may have been offset by increased rates of coverage from a spouse's employer (referred to as "spousal coverage"). Further, if this phenomenon has affected core and peripheral workers differently, it may explain some of the apparently widening gap between these groups of workers. The chief obstacle to analyzing this possibility is a lack of consistency in the data that are available over time on spousal coverage, which we discuss in more detail below. Given the limitations of the data, our results on spousal coverage should be interpreted cautiously.

With that caveat in mind, in order to explore the role of spousal coverage we begin by calculating the fraction of workers in each type of job who are married to another worker and, conditional on being married to another worker, the probability that the spouse is in a core job. 
This analysis establishes that there are not significant differences for core and peripheral workers in the probability of being married to another worker, while core workers are more likely (conditional on being married to another worker and after controlling for other factors such as age, sex, education and race) to be married to a core worker than are peripheral workers.

By linking workers and their spouses in each year and using information from the March income supplements to the CPS for 1988, we are able to construct an estimate of the fraction of workers with spousal coverage. We use this measure to see how rates of own coverage, spousal coverage, and any coverage (the sum of own and spousal coverage) vary by type of job. We conclude by presenting a decomposition that is similar to the one in table 7 , but focuses on the change in the rate of coverage from any source (own policy or spousal coverage) so that we can say how changing rates of spousal coverage have affected the overall trend in insurance coverage.

\section{CPS Data on Spousal Coverage}

The information on health insurance coverage from sources other than a worker's own employer that is available from the CPS supplements varies over time. As a result, the method we use to construct a variable indicating coverage from a spouse's employer-sponsored policy in 1995 and 1997 differs from the method used for 1988 or 1993 . In 1995 and 1997 it is straightforward to determine which workers not covered by their own employer-sponsored coverage were covered by a spouse's policy, because the survey asked persons reporting that they were not covered by their own policy whether they had any other health insurance, and if so, what was the source of that insurance. "Spouse's employer policy" was one of the options listed as a possible source, so we code anyone who reported that as having spousal coverage.

Both the May 1988 and the April 1993 CPS public use data files include variables based on questions from the March supplement about health insurance during the previous calendar year. ${ }^{12}$ In 1993 it is not necessary to use these to get information about spousal coverage because all workers, including those reporting own employer coverage, were asked about other sources of

\footnotetext{
${ }^{12}$ While the March CPS questions refer in theory to health insurance held during the previous calendar year, Swartz (1986) presents evidence that people may respond as if the questions were asked about health insurance as of the survey date. This may explain why the March 1993 questions (which are in theory asked about health insurance during calendar year 1992) and April 1993 questions (which are in theory asked about health insurance as of the survey date in April 1993) yield very similar estimates of spousal coverage.
} 
coverage, and again "spouse's employer policy" was an option, so for 1993 we use responses to that question to determine spousal coverage. In 1988, workers who declined coverage were asked whether they had any other coverage, including spousal coverage; however, workers not offered insurance were not asked about other coverage.

In order to identify which workers in 1988 who were not offered health insurance were in fact covered by a spouse's policy, and also to identify in all years whether or not an individual's spouse was employed, we use household and spouse identifiers to link individuals to their spouses. This match was successful for 99.0 percent of all married people in our sample; the 555 married respondents for whom no spouse was found were dropped from the sample. An additional 4,170 respondents were dropped because information was not available on their spouse's work status or (for individuals with working spouses) the spouse's job tenure, hours, or health insurance. This leaves us with a working sample of 90,721 observations: 35,706 single workers, 13,164 workers married to non-workers, and 41,851 married workers with working spouses having usable employment data. ${ }^{13}$

In order to construct a spousal coverage variable for 1988, we used the spouse's responses to questions from the March supplement about health insurance coverage. Individuals with a spouse who reported employer-sponsored coverage that also covered their spouse (i.e. the individual) were coded as having spousal coverage. Simulations using the linked April-March 1993 CPS files suggests that this procedure biases our estimate of spousal coverage in 1988 upward by approximately .007 on average, and (somewhat surprisingly) that there is no reason to think that this bias affects core and peripheral workers differently, since estimates of the core-peripheral differential for 1993 do not change significantly when using the 1988 method to code spousal coverage in 1993.

Finally, in all years, we imposed a series of consistency checks on the spousal coverage variable that consisted of recoding spousal coverage to zero if an individual was not married, if the individual's spouse did not report having own-employer coverage, or if the individual's spouse was not a worker, which lowers the fraction with spousal coverage by about one percentage point in each year. We believe that this procedure results in a set of variables that is

\footnotetext{
${ }^{13}$ This change in the sample explains the slight differences in means between the first two panels of table 7 and the corresponding entries in table 12.
} 
as consistent as it is possible to produce with the information that is available from these supplements.

\section{The Prevalence of Dual-Worker Couples}

In order to determine the importance of spousal coverage as a source of health insurance, we first calculate the fraction of workers who are married to another worker, which we term here the prevalence of dual-worker couples. ${ }^{14}$ Table 8 presents the average fraction of workers who are married to another worker, by job category. Overall, 46.7 percent of private-sector workers are married to another worker, and this rate is fairly stable over time. ${ }^{15}$ Part-time workers on old jobs appear most likely to be married to another worker; however, when regression-adjusting for age, sex, and education, the core-peripheral difference becomes zero. ${ }^{16}$ This suggests that any differences between core and peripheral workers in spousal coverage rates do not arise from differences in the probability of being married to another worker.

Table 9 restricts the sample to private-sector workers who are married to another worker (who may be employed in the public sector) and presents the fraction of workers whose spouse is in a core job, since that has been shown to affect the availability of health insurance. While on average the probability of having a spouse in a core job is approximately the same for core and peripheral workers, after regression-adjusting for age, race, education and sex, peripheral workers are about five percentage points less likely than core workers to be married to a core worker.

\section{Trends in Health Insurance for Dual-Worker Couples}

Table 10 presents average rates of spousal coverage during the 1988-1997 period, both overall and by type of job. Overall, 10.3 percent of workers have spousal coverage, and there is a small increase in this rate over time, from 9.4 percent in 1988 to 10.9 percent in 1997. Peripheral

\footnotetext{
${ }^{14}$ Note that we do not use this phrase to mean the fraction of couples that have two workers, which might in another context be a more natural definition.

${ }^{15}$ This includes private sector workers married to public-sector workers; workers not married to another worker include both single workers and workers married to nonworkers.

${ }^{16}$ Some of the coefficients in this regression are quite interesting: women workers are more likely than men to be married to another worker, and age exhibits a hill-shaped pattern, with middle-aged workers the most likely to be married to other workers. These results are available from the authors upon request.
} 
workers-part-time workers on old jobs in particular-have much higher rates of spousal coverage than core workers.

Table 11 adds the information on spousal coverage contained in table 10 to the information on own coverage from table 2 and presents the rate of employer-sponsored coverage from any source by type of job. While the raw differences in rates of any coverage between core and peripheral workers are smaller than were the differences in own coverage reported in table 2, they are still large (32.6 percentage points on average) and increasing over time (from 29.5 percentage points in 1988 to 33.5 percentage points in 1997). The regression-adjusted differentials are slightly smaller (29.0 percentage points on average) but exhibit a similar trend. ${ }^{17}$

\section{Adding Spousal Coverage to the Decomposition}

In order to determine how much of the decline in own-employer group coverage is offset by the increase in spousal coverage, we analyze changes in the rate of employer-sponsored coverage from any source using an amended version of the decomposition described in section 8 . We begin by writing the rate of coverage by any employer-sponsored health insurance, $H I_{t}$, as the sum of own-employer coverage and spousal coverage:

$$
H I_{t}=C_{t}+S_{t}
$$

where $C_{t}$ and $S_{t}$ represent own coverage and spousal coverage as defined above. Writing the change in the overall rate of group insurance coverage as

$$
\Delta H I=\Delta C+\Delta S
$$

and substituting the right-hand side of equation 3 above for $\Delta C$ yields a five-term decomposition of $\Delta H I$ :

\footnotetext{
${ }^{17}$ Regression-adjusted differentials in tables 9 through 11 do not include marital status dummies. In table 8 the outcome of interest is directly related to marriage; in table 9 an individual must be married in order to be included in the regression. In tables 10 and 11, the marital status dummy is omitted since we want to capture the differential probabilities of marriage for core and peripheral workers in the peripheral dummy variable rather than explicitly controlling for it.
} 


$$
\Delta H I=\Delta O \cdot E \cdot T+\Delta E \cdot O \cdot T+\Delta T \cdot O \cdot E+\operatorname{cov}+\Delta S
$$

We can also decompose the change in spousal coverage by worker group as in section 7 :

$$
\Delta S=\alpha_{1} \Delta S_{1}+\alpha_{2} \Delta S_{2}+\alpha_{3} \Delta S_{3}+\alpha_{4} \Delta S_{4}
$$

and substitute this result into equation (10). Doing this and expanding the other elements of the decomposition as before (shown in equations 4 through 6) yields the following expression for the change in overall health insurance coverage rates:

$$
\begin{aligned}
\Delta H I= & \left(\alpha_{1} \Delta O_{1} \cdot E \cdot T+\alpha_{2} \Delta O_{2} \cdot E \cdot T+\alpha_{3} \Delta O_{3} \cdot E \cdot T+\alpha_{4} \Delta O_{4} \cdot E \cdot T\right)+ \\
& \left(\alpha_{1} \Delta E_{1} \cdot O \cdot T+\alpha_{2} \Delta E_{2} \cdot O \cdot T+\alpha_{3} \Delta E_{3} \cdot O \cdot T+\alpha_{4} \Delta E_{4} \cdot O \cdot T\right)+ \\
& \left(\alpha_{1} \Delta T_{1} \cdot O \cdot E+\alpha_{2} \Delta T_{2} \cdot O \cdot E+\alpha_{3} \Delta T_{3} \cdot O \cdot E+\alpha_{4} \Delta T_{4} \cdot O \cdot E\right)+ \\
& \left(\alpha_{1} \Delta S_{1}+\alpha_{2} \Delta S_{2}+\alpha_{3} \Delta S_{3}+\alpha_{4} \Delta S_{4}\right)+\operatorname{cov}
\end{aligned}
$$

We proceed as in section 7 by performing this decomposition separately for each subgroup of workers. We also present overall results based on weighting the elements of each decomposition by the group's employment share.

Table 12 presents the results of these decompositions. The addition of spousal coverage changes the results noticeably: more than half of the decline in takeup (or approximately half of the total decline in coverage that would otherwise have occurred) for core workers is offset by the increase in spousal coverage for this group. Increases in spousal coverage also offset about one-fifth of the effect of takeup and eligibility declines for new full-time workers. For both old and new part-time workers, however, decreases in spousal coverage contribute to rather than offset the decline in overall coverage that occurred for these groups. Thus, adding spousal coverage to the analysis lends further support to the view that peripheral workers have been harder hit by declining benefits than have core workers.

\section{Analysis by Educational Category}

We would also like to know whether declines in health insurance have disproportionately affected workers with less education. Katz and Murphy (1992) document a substantial increase in the college wage premium between 1979 and 1987, so we are particularly interested in any 
differences in trends in health insurance coverage for college-educated workers and those with less education over that period. Therefore, we replicate the preceding analysis, this time categorizing workers by their educational attainment instead of core/peripheral status. We present results based on two categories: four years of college or more versus less than four years of college. We also present trends for workers with less than four years of college broken down into three finer categories: less than high school, high school graduate, and some college (but less than four years).

Table 13 shows trends in own health insurance coverage by educational category for all workers from 1979 to 1997 . At any point in time, the coverage rate increases monotonically with workers' education. Moreover, while workers with less than four years of college experienced a decrease in the coverage rate from 70.4 percent in 1979 to 65.7 percent in 1988 (column 3), coverage for college graduates increased over the same period from 80.6 percent to 81.9 percent (column 2). As a result, the college/noncollege differential in health insurance coverage increased from 10.2 percentage points in 1979 to 16.2 percentage points in 1988 (column 7). This result suggests that if health insurance were taken into account, the picture for less-educated workers would appear to have grown even bleaker (relative to more highly educated workers) over the 1979-1988 period than an analysis of wages alone would suggest. This is consistent with a recent study by Brooks Pierce (1998) using data from the Employment Cost Index to show that the dispersion of compensation (wages plus health insurance plus pensions) is greater than the dispersion of wages alone at a point in time, and has also increased more in the past 10-15 years.

Since 1988, the coverage differential between college graduates and those with less education has remained more or less constant. This is because college graduates experienced a decline in coverage between 1988 and 1993 of approximately the same absolute size as that experienced by less-educated workers (about 4.5 percentage points). Thus, adding health insurance to an analysis of more recent wage changes would increase cross-sectional inequality in compensation but would not necessarily contribute to any increase in inequality over the 1988-1997 period.

We also perform an analysis of trends in different components of coverage (offering, eligibility and takeup) over the 1988-1997 period by education category separately for all workers, core workers, and peripheral workers. The highlights of these analyses are presented in 
the decompositions in tables 14,15 and $16 .{ }^{18}$ Because the distribution of employment across educational categories was not stable over this period, we present only within-group decompositions and omit the decomposition weighted by employment share that was presented earlier.

The results of the decomposition reveal striking differences in the factors underlying the coverage trends for workers with different levels of education. The overall decomposition for both core and peripheral workers is presented in table 14. This table shows that workers who did not complete high school experienced declines in all components of coverage, including offering. The most highly educated group of workers, by contrast, experienced the smallest decline in eligibility, and the largest offsetting increase in spousal coverage. In general, as education level increases, workers experience smaller declines in coverage, the share of the decline that is attributable to changes in takeup increases, the share of the decline that is attributable to changes in eligibility decreases, and the offsetting effect of spousal coverage increases.

Disaggregating workers into core and peripheral and repeating the analysis by education category reveals interesting differences between the two types of jobs in the effect of education on coverage trends. While trends by education category for workers on core jobs look very much like those for all workers discussed in the previous paragraph (see table 15), education did not serve uniformly as a buffer against declines in health insurance for peripheral workers (table 16). Peripheral workers were affected across the board by declines in eligibility, regardless of their education level. However, more highly-educated peripheral workers were still better off than their less-educated counterparts. For peripheral workers with less than a high school education, spousal coverage declined as much as did own coverage, while more highly-educated workers saw very little change in rates of spousal coverage. Overall, then, education protected workers on core jobs against coverage declines but offered only limited protection to workers on peripheral jobs against declines in coverage.

\footnotetext{
${ }^{18}$ Complete results of the supporting analysis are in an appendix available from the authors.
} 


\section{Conclusion}

The fact that declines in eligibility and takeup are more important causes of the decline in coverage than is any decline in offering suggests to us that reductions in health insurance are occurring primarily within firms. That is, we find no evidence in either establishment-level or individual-level data that firms are dropping coverage at a substantial rate. Instead, our analysis of the CPS suggests that two factors are primarily responsible for declines in coverage. The first factor is a decline in takeup for core workers, more than half of which is offset by an increase in the rate of spousal coverage for these workers. The second factor is a decline in eligibility that is particularly large for new full-time workers and old part-time workers. While about four-tenths of the eligibility decline for new full-time workers is offset by an increase in spousal coverage, declines in the rate of own coverage for both new and old part-time workers are exacerbated by declining rates of spousal coverage as well. Moreover, we find that among core workers, the least educated workers were hardest hit by these declines, while among peripheral workers the declines occurred across the board regardless of workers' education level. Thus, the evidence is consistent with the view that employers are continuing to make health insurance available to their core long-term, full-time employees but are restricting access to health insurance by their peripheral short-term and part-time employees, so that the quality of core and peripheral jobs in this dimension is diverging. 


\section{References}

Abraham, Katharine G. and James L. Medoff. "Length of Service and Layoffs in Union and Nonunion Work Groups," Industrial and Labor Relations Review 38 (October 1984): pp. 8797.

Blostin, Alan P. and Jordan N. Pfuntner. "Employee Medical Care Contributions on the Rise," Compensation and Working Conditions (Spring 1998): pp. 46-51.

Bluestone, Barry and Bennett Harrison, "The Great American Jobs Machine," Study prepared for the U.S. Joint Economic Committee, December 1986.

Bluestone, Barry and Bennett Harrison, "The Growth of Low-Wage Employment: 1963-86," American Economic Review (May 1988): pp. 124-128.

Brown, Charles and James L. Medoff, “The Employer Size Wage Effect,” Journal of Political Economy 97 (October 1989): pp. 1027-59.

Cantor, Joel, Stephen Long and Susan Marquis, "Employment-Based Health Insurance in Ten States," Health Affairs (Summer 1995): pp. 199-211.

Costrell, Robert M. “Methodology in the Job Quality Debate," Industrial Relations 29 (1990): pp. 94-110.

Cooper, Philip F. and Barbara Steinberg Schone. "More Offers, Fewer Takers for EmploymentBased Health Insurance: 1987 and 1996," Health Affairs 16:6 (1997): pp. 142-149.

Cutler, David M. and Jonathan Gruber. "Does Public Insurance Crowd out Private Insurance," Quarterly Journal of Economics 111 (May 1996): pp. 391-430.

Farber, Henry S. "The Incidence and Costs of Job Loss: 1982-91," Brookings Papers on Economic Activity: Microeconomics, (1993,1), 73-119.

Farber, Henry S. "Are Lifetime Jobs Disappearing: Job Duration in the United States, 1973-93," Working Paper No. 341, Industrial Relations Section, Princeton University, January 1995. 
Forthcoming in Labor Statistics Measurement Issues, John Haltiwanger, Marilyn Manser, and Robert Topel, eds., University of Chicago Press, 1998. (in press).

Farber, Henry S. "Job Creation in the United States: Good Jobs or Bad?" Working Paper No. 385, Industrial Relations Section, Princeton University, July 1997.

Fronstin, Paul and Sarah C. Snider. "An Examination of the Decline in Employment-Based Health Insurance Between 1988 and 1993," Inquiry 33 (Winter 1996/97): pp. 317-325.

Houseman, Susan N. "Job Growth and the Quality of Jobs in the U.S. Economy," Labour (1995): pp. S93-S124.

Katz, Lawrence F. and Kevin M. Murphy. "Changes in Relative Wages, 1963-1987: Supply and Demand Factors," Quarterly Journal of Economics, 107(1), February 1992, pages 35-78.

Kosters, Marvin H. and Murray N. Ross. "A Shrinking Middle Class?" Public Interest (1988): pp. 3-27.

Krueger, Alan B. and Helen Levy. "Accounting for the Slowdown in Employer Health Care Costs," Proceedings of the Eighty-Ninth Annual Conference of the National Tax Association, 1996 (1997): 61-75.

Levy, Helen. "Who Pays for Health Insurance? Employee Contributions to Health Insurance Premiums," Working Paper No. 398, Industrial Relations Section, Princeton University, March 1998.

Pierce, Brooks. "Compensation Inequality." Unpublished manuscript, Bureau of Labor Statistics, April 1998.

Shore-Sheppard, Lara. "Stemming the Tide? The Effect of Expanding Medicaid Eligibility on Health Insurance Coverage,” Working Paper No. 361, Industrial Relations Section, Princeton University, April 1996. 
Swartz, Katherine. "Interpreting the Estimates from Four National Surveys of the Number of People Without Health Insurance," Journal of Economic and Social Measurement (1986) 14:233-242. 
Table 1

Fraction Covered by Health Insurance Provided by Their Employer

by Year and Sector (Private/Public)

Workers Ages 20-64

\begin{tabular}{|c|c|c|c|c|c|c|}
\hline Year & $\begin{array}{l}\text { Sample } \\
\text { Size }\end{array}$ & $\begin{array}{c}\text { All Jobs } \\
\text { Average } \\
\text { (1) }\end{array}$ & $\begin{array}{c}\text { Public } \\
\text { Average } \\
\text { (2) }\end{array}$ & $\begin{array}{c}\text { Private } \\
\text { Average } \\
\text { (3) }\end{array}$ & $\begin{array}{l}\text { Public-Private } \\
\text { Difference } \\
\text { Average } \\
\text { (4) }\end{array}$ & $\begin{array}{c}\text { Public-Private } \\
\text { Difference } \\
\text { Adjusted } \\
\text { (5) }\end{array}$ \\
\hline May79 & 4127 & $\begin{array}{c}0.734 \\
(0.003)\end{array}$ & $\begin{array}{c}0.796 \\
(0.005)\end{array}$ & $\begin{array}{c}0.719 \\
(0.003)\end{array}$ & $\begin{array}{c}0.076 \\
(0.007)\end{array}$ & $\begin{array}{c}0.067 \\
(0.008)\end{array}$ \\
\hline May83 & 4340 & $\begin{array}{c}0.726 \\
(0.003)\end{array}$ & $\begin{array}{c}0.811 \\
(0.005)\end{array}$ & $\begin{array}{c}0.706 \\
(0.003)\end{array}$ & $\begin{array}{c}0.106 \\
(0.007)\end{array}$ & $\begin{array}{c}0.078 \\
(0.008)\end{array}$ \\
\hline May88 & 3959 & $\begin{array}{c}0.713 \\
(0.003)\end{array}$ & $\begin{array}{c}0.814 \\
(0.005)\end{array}$ & $\begin{array}{c}0.691 \\
(0.003)\end{array}$ & $\begin{array}{c}0.124 \\
(0.006)\end{array}$ & $\begin{array}{c}0.092 \\
(0.008)\end{array}$ \\
\hline Apr93 & 3951 & $\begin{array}{c}0.677 \\
(0.002)\end{array}$ & $\begin{array}{c}0.807 \\
(0.005)\end{array}$ & $\begin{array}{c}0.647 \\
(0.003)\end{array}$ & $\begin{array}{c}0.160 \\
(0.006)\end{array}$ & $\begin{array}{c}0.124 \\
(0.008)\end{array}$ \\
\hline Feb95 & 8258 & $\begin{array}{c}0.675 \\
(0.003)\end{array}$ & $\begin{array}{c}0.819 \\
(0.007)\end{array}$ & $\begin{array}{c}0.641 \\
(0.004)\end{array}$ & $\begin{array}{c}0.178 \\
(0.009)\end{array}$ & $\begin{array}{c}0.142 \\
(0.006)\end{array}$ \\
\hline Feb97 & 7037 & $\begin{array}{c}0.674 \\
(0.003) \\
\end{array}$ & $\begin{array}{c}0.808 \\
(0.007) \\
\end{array}$ & $\begin{array}{c}0.645 \\
(0.004) \\
\end{array}$ & $\begin{array}{c}0.163 \\
(0.009)\end{array}$ & $\begin{array}{c}0.128 \\
(0.006)\end{array}$ \\
\hline All & 31672 & $\begin{array}{c}0.703 \\
(0.001)\end{array}$ & $\begin{array}{c}0.809 \\
(0.002)\end{array}$ & $\begin{array}{c}0.678 \\
(0.001)\end{array}$ & $\begin{array}{c}0.130 \\
(0.003)\end{array}$ & $\begin{array}{c}0.100 \\
(0.003)\end{array}$ \\
\hline
\end{tabular}

Note: The numbers in parentheses are standard errors. The numbers in columns 1-3 are the fraction of workers in each group reporting that they are covered by their own employer-provided health insurance based on weighted tabulations of data from the relevant supplements to the CPS. The average difference in column 4 is computed as the difference between the health insurance coverage rate in the public sector (column 2) and the coverage rate in the private sector (column 3). The adjusted differences reported in column 5 are the coefficients on a public sector dummy variable from separate OLS regressions for each year of the health insurance coverage indicator on the public sector dummy variable and controls for age, education, sex, race, marital status, and the interaction of sex and marital status. The regression adjustment for the "all" sample includes survey dummy variables as well. All counts are weighted by the CPS supplement weights. The sample includes all private sector workers ages 20-64 who are not self-employed. 
Table 2

Fraction Covered by Health Insurance Provided by Their Employer by Year and Job Type

Private Sector Workers Ages 20-64

\begin{tabular}{|c|c|c|c|c|c|c|c|c|c|}
\hline Year & $\begin{array}{c}\text { Sample } \\
\text { Size }\end{array}$ & $\begin{array}{c}\text { All Jobs } \\
\text { Average } \\
\text { (1) }\end{array}$ & $\begin{array}{c}\text { Full-time } \\
\text { Old (Core) } \\
\text { Jobs Average } \\
\text { (2) }\end{array}$ & $\begin{array}{l}\text { Peripheral } \\
\text { Jobs } \\
\text { Average } \\
(3)\end{array}$ & $\begin{array}{c}\text { Full-time } \\
\text { New Jobs } \\
\text { Average } \\
\text { (4) }\end{array}$ & $\begin{array}{c}\text { Part-time } \\
\text { Old Jobs } \\
\text { Average } \\
\quad(5)\end{array}$ & $\begin{array}{c}\text { Part-time } \\
\text { New Jobs } \\
\text { Average } \\
(6)\end{array}$ & $\begin{array}{c}\text { Periph.-Core } \\
\text { Difference } \\
\text { Average } \\
\text { (7) }\end{array}$ & $\begin{array}{c}\text { Periph.-Core } \\
\text { Difference } \\
\text { Adjusted } \\
(8)\end{array}$ \\
\hline May79 & 15706 & $\begin{array}{c}0.719 \\
(0.003)\end{array}$ & $\begin{array}{c}0.828 \\
(0.003)\end{array}$ & $\begin{array}{c}0.454 \\
(0.006)\end{array}$ & $\begin{array}{c}0.604 \\
(0.008)\end{array}$ & $\begin{array}{c}0.271 \\
(0.011)\end{array}$ & $\begin{array}{c}0.123 \\
(0.010)\end{array}$ & $\begin{array}{l}-0.374 \\
(0.006)\end{array}$ & $\begin{array}{l}-0.329 \\
(0.008)\end{array}$ \\
\hline May83 & 16970 & $\begin{array}{c}0.706 \\
(0.003)\end{array}$ & $\begin{array}{c}0.835 \\
(0.003)\end{array}$ & $\begin{array}{c}0.376 \\
(0.006)\end{array}$ & $\begin{array}{c}0.501 \\
(0.009)\end{array}$ & $\begin{array}{c}0.341 \\
(0.009)\end{array}$ & $\begin{array}{c}0.100 \\
(0.009)\end{array}$ & $\begin{array}{l}-0.459 \\
(0.006)\end{array}$ & $\begin{array}{l}-0.415 \\
(0.007)\end{array}$ \\
\hline May88 & 16039 & $\begin{array}{c}0.691 \\
(0.003)\end{array}$ & $\begin{array}{c}0.813 \\
(0.003)\end{array}$ & $\begin{array}{c}0.396 \\
(0.005)\end{array}$ & $\begin{array}{c}0.529 \\
(0.008)\end{array}$ & $\begin{array}{c}0.291 \\
(0.009)\end{array}$ & $\begin{array}{c}0.098 \\
(0.009)\end{array}$ & $\begin{array}{l}-0.416 \\
(0.006)\end{array}$ & $\begin{array}{l}-0.372 \\
(0.007)\end{array}$ \\
\hline Apr93 & 15711 & $\begin{array}{c}0.647 \\
(0.003)\end{array}$ & $\begin{array}{c}0.770 \\
(0.003)\end{array}$ & $\begin{array}{c}0.325 \\
(0.005)\end{array}$ & $\begin{array}{c}0.447 \\
(0.008)\end{array}$ & $\begin{array}{c}0.274 \\
(0.008)\end{array}$ & $\begin{array}{c}0.073 \\
(0.008)\end{array}$ & $\begin{array}{l}-0.446 \\
(0.006)\end{array}$ & $\begin{array}{l}-0.403 \\
(0.008)\end{array}$ \\
\hline Feb95 & 33693 & $\begin{array}{c}0.641 \\
(0.004)\end{array}$ & $\begin{array}{c}0.770 \\
(0.004)\end{array}$ & $\begin{array}{c}0.333 \\
(0.007)\end{array}$ & $\begin{array}{c}0.447 \\
(0.011)\end{array}$ & $\begin{array}{c}0.264 \\
(0.012)\end{array}$ & $\begin{array}{c}0.095 \\
(0.012)\end{array}$ & $\begin{array}{l}-0.437 \\
(0.008)\end{array}$ & $\begin{array}{l}-0.404 \\
(0.005)\end{array}$ \\
\hline Feb97 & 30003 & $\begin{array}{c}0.645 \\
(0.004) \\
\end{array}$ & $\begin{array}{c}0.770 \\
(0.004) \\
\end{array}$ & $\begin{array}{c}0.341 \\
(0.007) \\
\end{array}$ & $\begin{array}{c}0.459 \\
(0.011) \\
\end{array}$ & $\begin{array}{c}0.269 \\
(0.012) \\
\end{array}$ & $\begin{array}{c}0.087 \\
(0.012) \\
\end{array}$ & $\begin{array}{l}-0.429 \\
(0.008)\end{array}$ & $\begin{array}{l}-0.393 \\
(0.006)\end{array}$ \\
\hline All & 95511 & $\begin{array}{c}0.678 \\
(0.001)\end{array}$ & $\begin{array}{c}0.801 \\
(0.001)\end{array}$ & $\begin{array}{c}0.374 \\
(0.003)\end{array}$ & $\begin{array}{c}0.507 \\
(0.004)\end{array}$ & $\begin{array}{c}0.288 \\
(0.004)\end{array}$ & $\begin{array}{c}0.095 \\
(0.004)\end{array}$ & $\begin{array}{l}-0.427 \\
(0.003)\end{array}$ & $\begin{array}{l}-0.386 \\
(0.003)\end{array}$ \\
\hline
\end{tabular}

Note: The numbers in parentheses are standard errors. The numbers in columns 1-6 are the fraction of workers in each group reporting that they are covered by their own employer-provided health insurance based on weighted tabulations of data from the relevant supplements to the CPS. The average difference in column 7 is computed as the difference between the health insurance coverage rate for workers in peripheral jobs (column 3 ) and the coverage rate for workers in core jobs (column 2). The adjusted differences reported in column 8 are the coefficients on a peripheral job dummy variable from separate OLS regressions for each year of the health insurance coverage indicator on the peripheral job dummy variable and controls for age, education, sex, race, marital status, and the interaction of sex and marital status. The regression adjustment for the "all" sample includes survey dummy variables as well. All counts are weighted by the CPS supplement weights. The sample includes all private sector workers ages 20-64 who are not self-employed. 
Table 3

Fraction of Workforce with Less than One Year of Tenure and Fraction Part-time

And Distribution across Job Categories

By Year, Private Sector

\begin{tabular}{|c|c|c|c|c|c|c|c|}
\hline \multirow[b]{3}{*}{ Year } & \multirow[b]{3}{*}{$\begin{array}{l}\text { Sample } \\
\text { Size }\end{array}$} & \multirow[b]{3}{*}{$\begin{array}{c}\text { Fraction } \\
\text { New } \\
(1)\end{array}$} & \multirow[b]{3}{*}{$\begin{array}{c}\text { Fraction } \\
\text { Part-Time } \\
\quad(2)\end{array}$} & \multicolumn{4}{|c|}{ Distribution of Employment } \\
\hline & & & & Core & & Peripheral & \\
\hline & & & & $\begin{array}{c}\text { Full-time } \\
\text { Old } \\
\text { (3) }\end{array}$ & $\begin{array}{c}\text { Full-time } \\
\text { New } \\
(4)\end{array}$ & $\begin{array}{l}\text { Part-time } \\
\text { Old } \\
\text { (5) }\end{array}$ & $\begin{array}{c}\text { Part-time } \\
\text { New } \\
(6)\end{array}$ \\
\hline May79 & 15949 & $\begin{array}{c}0.220 \\
(0.003)\end{array}$ & $\begin{array}{c}0.117 \\
(0.003)\end{array}$ & $\begin{array}{c}0.703 \\
(0.004)\end{array}$ & $\begin{array}{c}0.180 \\
(0.003)\end{array}$ & $\begin{array}{c}0.078 \\
(0.002)\end{array}$ & $\begin{array}{c}0.040 \\
(0.002)\end{array}$ \\
\hline Jan83 & 9763 & $\begin{array}{c}0.208 \\
(0.003)\end{array}$ & $\begin{array}{c}0.164 \\
(0.003)\end{array}$ & $\begin{array}{c}0.687 \\
(0.003)\end{array}$ & $\begin{array}{c}0.149 \\
(0.003)\end{array}$ & $\begin{array}{c}0.105 \\
(0.002)\end{array}$ & $\begin{array}{c}0.059 \\
(0.002)\end{array}$ \\
\hline May83 & 17142 & $\begin{array}{c}0.185 \\
(0.003)\end{array}$ & $\begin{array}{c}0.149 \\
(0.003)\end{array}$ & $\begin{array}{c}0.714 \\
(0.004)\end{array}$ & $\begin{array}{c}0.137 \\
(0.003)\end{array}$ & $\begin{array}{c}0.101 \\
(0.002)\end{array}$ & $\begin{array}{c}0.049 \\
(0.002)\end{array}$ \\
\hline Jan87 & 10382 & $\begin{array}{c}0.210 \\
(0.003)\end{array}$ & $\begin{array}{c}0.145 \\
(0.002)\end{array}$ & $\begin{array}{c}0.698 \\
(0.003)\end{array}$ & $\begin{array}{c}0.158 \\
(0.002)\end{array}$ & $\begin{array}{c}0.093 \\
(0.002)\end{array}$ & $\begin{array}{c}0.052 \\
(0.001)\end{array}$ \\
\hline May88 & 16693 & $\begin{array}{c}0.217 \\
(0.003)\end{array}$ & $\begin{array}{c}0.134 \\
(0.003)\end{array}$ & $\begin{array}{c}0.696 \\
(0.003)\end{array}$ & $\begin{array}{l}0.170 \\
(0.003)\end{array}$ & $\begin{array}{c}0.088 \\
(0.002)\end{array}$ & $\begin{array}{c}0.047 \\
(0.002)\end{array}$ \\
\hline Jan91 & 10034 & $\begin{array}{c}0.198 \\
(0.003)\end{array}$ & $\begin{array}{c}0.144 \\
(0.002)\end{array}$ & $\begin{array}{c}0.705 \\
(0.003)\end{array}$ & $\begin{array}{c}0.152 \\
(0.003)\end{array}$ & $\begin{array}{c}0.097 \\
(0.002)\end{array}$ & $\begin{array}{c}0.047 \\
(0.001)\end{array}$ \\
\hline Apr93 & 16253 & $\begin{array}{c}0.186 \\
(0.003)\end{array}$ & $\begin{array}{c}0.152 \\
(0.003)\end{array}$ & $\begin{array}{c}0.711 \\
(0.003)\end{array}$ & $\begin{array}{c}0.137 \\
(0.003)\end{array}$ & $\begin{array}{c}0.103 \\
(0.002)\end{array}$ & $\begin{array}{c}0.049 \\
(0.002)\end{array}$ \\
\hline Feb95 & 35140 & $\begin{array}{c}0.207 \\
(0.003)\end{array}$ & $\begin{array}{c}0.150 \\
(0.002)\end{array}$ & $\begin{array}{c}0.693 \\
(0.003)\end{array}$ & $\begin{array}{c}0.157 \\
(0.003)\end{array}$ & $\begin{array}{c}0.100 \\
(0.002)\end{array}$ & $\begin{array}{c}0.050 \\
(0.001)\end{array}$ \\
\hline Feb96 & 28041 & $\begin{array}{c}0.214 \\
(0.003)\end{array}$ & $\begin{array}{c}0.141 \\
(0.003)\end{array}$ & $\begin{array}{c}0.695 \\
(0.003)\end{array}$ & $\begin{array}{c}0.164 \\
(0.003)\end{array}$ & $\begin{array}{c}0.091 \\
(0.002)\end{array}$ & $\begin{array}{c}0.050 \\
(0.002)\end{array}$ \\
\hline Feb97 & 31288 & $\begin{array}{c}0.203 \\
(0.003) \\
\end{array}$ & $\begin{array}{c}0.146 \\
(0.002) \\
\end{array}$ & $\begin{array}{c}0.698 \\
(0.003)\end{array}$ & $\begin{array}{c}0.156 \\
(0.002)\end{array}$ & $\begin{array}{c}0.099 \\
(0.002)\end{array}$ & $\begin{array}{c}0.047 \\
(0.001) \\
\end{array}$ \\
\hline All & 190685 & $\begin{array}{c}0.205 \\
(0.001)\end{array}$ & $\begin{array}{c}0.145 \\
(0.001)\end{array}$ & $\begin{array}{c}0.700 \\
(0.001)\end{array}$ & $\begin{array}{c}0.156 \\
(0.001)\end{array}$ & $\begin{array}{c}0.096 \\
(0.001)\end{array}$ & $\begin{array}{c}0.049 \\
(0.001)\end{array}$ \\
\hline
\end{tabular}

Note: The numbers in columns 1 are the fraction of workers in each group with tenure less than one year based on weighted tabulations of data from the relevant supplements to the CPS. The numerator is the number of those employed who report working continuously for their current employer for less than one year. The denominator is the total number employed. The numbers in column 2 are the fraction of workers who report usually working 35 hours or less per week. Columns 3-6 show the distribution of workers into different job type categories. All counts are weighted by the CPS final sampling weights. Self-employed workers and workers with missing data on tenure or hours of work are not included in the analysis. Incorporated self-employed workers are included in May 1979. The sample includes workers aged 20-64 only. 
Table 4

Fraction Whose Employers Offer Health Insurance Coverage to at least Some Employees by Year and Job Type

Private Sector Workers Ages 20-64

\begin{tabular}{|c|c|c|c|c|c|c|c|c|c|}
\hline Year & $\begin{array}{c}\text { Sample } \\
\text { Size }\end{array}$ & $\begin{array}{c}\text { All Jobs } \\
\text { Average } \\
(1)\end{array}$ & $\begin{array}{c}\text { Full-time } \\
\text { Old (Core) } \\
\text { Jobs Average } \\
(2)\end{array}$ & $\begin{array}{c}\text { Peripheral } \\
\text { Jobs } \\
\text { Average } \\
(3)\end{array}$ & $\begin{array}{c}\text { Full-time } \\
\text { New Jobs } \\
\text { Average } \\
\text { (4) }\end{array}$ & $\begin{array}{c}\text { Part-time } \\
\text { Old Jobs } \\
\text { Average } \\
\text { (5) }\end{array}$ & $\begin{array}{c}\text { Part-time } \\
\text { New Jobs } \\
\text { Average } \\
(6)\end{array}$ & $\begin{array}{c}\text { Periph.-Core } \\
\text { Difference } \\
\text { Average } \\
(7)\end{array}$ & $\begin{array}{c}\text { Periph.-Core } \\
\text { Difference } \\
\text { Adjusted } \\
(8)\end{array}$ \\
\hline May88 & 16084 & $\begin{array}{c}0.827 \\
(0.002)\end{array}$ & $\begin{array}{c}0.888 \\
(0.002)\end{array}$ & $\begin{array}{c}0.682 \\
(0.005)\end{array}$ & $\begin{array}{c}0.763 \\
(0.006)\end{array}$ & $\begin{array}{c}0.625 \\
(0.009)\end{array}$ & $\begin{array}{c}0.480 \\
(0.014)\end{array}$ & $\begin{array}{l}-0.206 \\
(0.005)\end{array}$ & $\begin{array}{l}-0.185 \\
(0.007)\end{array}$ \\
\hline Apr93 & 15731 & $\begin{array}{c}0.805 \\
(0.002)\end{array}$ & $\begin{array}{c}0.870 \\
(0.002)\end{array}$ & $\begin{array}{c}0.635 \\
(0.005)\end{array}$ & $\begin{array}{c}0.704 \\
(0.007)\end{array}$ & $\begin{array}{c}0.632 \\
(0.008)\end{array}$ & $\begin{array}{c}0.435 \\
(0.013)\end{array}$ & $\begin{array}{l}-0.235 \\
(0.005)\end{array}$ & $\begin{array}{l}-0.214 \\
(0.007)\end{array}$ \\
\hline Feb95 & 33693 & $\begin{array}{c}0.826 \\
(0.003)\end{array}$ & $\begin{array}{c}0.883 \\
(0.003)\end{array}$ & $\begin{array}{c}0.688 \\
(0.007)\end{array}$ & $\begin{array}{c}0.754 \\
(0.009)\end{array}$ & $\begin{array}{c}0.653 \\
(0.012)\end{array}$ & $\begin{array}{c}0.538 \\
(0.018)\end{array}$ & $\begin{array}{l}-0.195 \\
(0.006)\end{array}$ & $\begin{array}{l}-0.180 \\
(0.005)\end{array}$ \\
\hline Feb97 & 30003 & $\begin{array}{c}0.835 \\
(0.003) \\
\end{array}$ & $\begin{array}{c}0.889 \\
(0.003) \\
\end{array}$ & $\begin{array}{c}0.703 \\
(0.007) \\
\end{array}$ & $\begin{array}{c}0.759 \\
(0.009) \\
\end{array}$ & $\begin{array}{c}0.675 \\
(0.012) \\
\end{array}$ & $\begin{array}{c}0.568 \\
(0.019) \\
\end{array}$ & $\begin{array}{l}-0.186 \\
(0.006) \\
\end{array}$ & $\begin{array}{l}-0.174 \\
(0.005) \\
\end{array}$ \\
\hline All & 95511 & $\begin{array}{c}0.821 \\
(0.001)\end{array}$ & $\begin{array}{c}0.881 \\
(0.001)\end{array}$ & $\begin{array}{c}0.672 \\
(0.003)\end{array}$ & $\begin{array}{c}0.744 \\
(0.004)\end{array}$ & $\begin{array}{c}0.641 \\
(0.005)\end{array}$ & $\begin{array}{c}0.490 \\
(0.008)\end{array}$ & $\begin{array}{l}-0.210 \\
(0.003)\end{array}$ & $\begin{array}{l}-0.192 \\
(0.003)\end{array}$ \\
\hline
\end{tabular}

Note: The numbers in parentheses are standard errors. The numbers in columns 1-6 are the fraction of workers in each group who are in a firm that offers health insurance to at least some workers in the firm based on weighted tabulations of data from the relevant supplements to the CPS. The average difference in column 7 is computed as the difference between the health insurance offer rate for workers in peripheral jobs (column 3 ) and the offer rate for workers in core jobs (column 2). The adjusted differences reported in column 8 are the coefficients on a peripheral job dummy variable from separate OLS regressions for each year of the health insurance offering indicator on the peripheral job dummy variable and controls for age, education, sex, race, marital status, and the interaction of sex and marital status. The regression adjustment for the "all" sample includes survey dummy variables as well. All counts are weighted by the CPS supplement weights. The sample includes all private sector workers ages 20-64 who are not self-employed. 
Table 5

Fraction Eligible for Health Insurance Coverage Conditional on Employer Offering by Year and Job Type

Private Sector Workers Ages 20-64

\begin{tabular}{|c|c|c|c|c|c|c|c|c|c|}
\hline Year & $\begin{array}{c}\text { Sample } \\
\text { Size }\end{array}$ & $\begin{array}{c}\text { All Jobs } \\
\text { Average } \\
\text { (1) }\end{array}$ & $\begin{array}{c}\text { Full-time } \\
\text { Old (Core) } \\
\text { Jobs Average } \\
\text { (2) }\end{array}$ & $\begin{array}{l}\text { Peripheral } \\
\text { Jobs } \\
\text { Average } \\
\text { (3) }\end{array}$ & $\begin{array}{c}\text { Full-time } \\
\text { New Jobs } \\
\text { Average } \\
\text { (4) }\end{array}$ & $\begin{array}{c}\text { Part-time } \\
\text { Old Jobs } \\
\text { Average } \\
\text { (5) }\end{array}$ & $\begin{array}{c}\text { Part-time } \\
\text { New Jobs } \\
\text { Average } \\
(6)\end{array}$ & $\begin{array}{c}\text { Periph.-Core } \\
\text { Difference } \\
\text { Average } \\
\text { (7) }\end{array}$ & $\begin{array}{c}\text { Periph.-Core } \\
\text { Difference } \\
\text { Adjusted } \\
(8)\end{array}$ \\
\hline May88 & 16084 & $\begin{array}{c}0.943 \\
(0.002)\end{array}$ & $\begin{array}{c}0.990 \\
(0.001)\end{array}$ & $\begin{array}{c}0.798 \\
(0.006)\end{array}$ & $\begin{array}{c}0.841 \\
(0.006)\end{array}$ & $\begin{array}{c}0.780 \\
(0.011)\end{array}$ & $\begin{array}{c}0.586 \\
(0.019)\end{array}$ & $\begin{array}{l}-0.191 \\
(0.004)\end{array}$ & $\begin{array}{l}-0.181 \\
(0.005)\end{array}$ \\
\hline Apr93 & 15731 & $\begin{array}{c}0.917 \\
(0.002)\end{array}$ & $\begin{array}{c}0.976 \\
(0.001)\end{array}$ & $\begin{array}{c}0.710 \\
(0.006)\end{array}$ & $\begin{array}{c}0.788 \\
(0.007)\end{array}$ & $\begin{array}{c}0.692 \\
(0.010)\end{array}$ & $\begin{array}{c}0.389 \\
(0.019)\end{array}$ & $\begin{array}{l}-0.266 \\
(0.004)\end{array}$ & $\begin{array}{l}-0.248 \\
(0.006)\end{array}$ \\
\hline Feb95 & 33584 & $\begin{array}{c}0.912 \\
(0.002)\end{array}$ & $\begin{array}{c}0.976 \\
(0.001)\end{array}$ & $\begin{array}{c}0.702 \\
(0.008)\end{array}$ & $\begin{array}{c}0.768 \\
(0.009)\end{array}$ & $\begin{array}{c}0.691 \\
(0.014)\end{array}$ & $\begin{array}{c}0.406 \\
(0.024)\end{array}$ & $\begin{array}{l}-0.278 \\
(0.005)\end{array}$ & $\begin{array}{l}-0.265 \\
(0.004)\end{array}$ \\
\hline Feb97 & 29971 & $\begin{array}{c}0.912 \\
(0.002)\end{array}$ & $\begin{array}{c}0.982 \\
(0.001)\end{array}$ & $\begin{array}{c}0.696 \\
(0.007)\end{array}$ & $\begin{array}{c}0.781 \\
(0.009)\end{array}$ & $\begin{array}{c}0.671 \\
(0.013)\end{array}$ & $\begin{array}{c}0.355 \\
(0.024)\end{array}$ & $\begin{array}{l}-0.287 \\
(0.005)\end{array}$ & $\begin{array}{l}-0.268 \\
(0.004)\end{array}$ \\
\hline All & 95316 & $\begin{array}{c}0.924 \\
(0.001)\end{array}$ & $\begin{array}{c}0.982 \\
(0.001)\end{array}$ & $\begin{array}{c}0.735 \\
(0.003)\end{array}$ & $\begin{array}{c}0.803 \\
(0.004)\end{array}$ & $\begin{array}{c}0.713 \\
(0.006)\end{array}$ & $\begin{array}{c}0.447 \\
(0.011)\end{array}$ & $\begin{array}{l}-0.247 \\
(0.002)\end{array}$ & $\begin{array}{l}-0.233 \\
(0.002)\end{array}$ \\
\hline
\end{tabular}

Note: The numbers in parentheses are standard errors. The numbers in columns 1-6 are the fraction of workers in each group who are eligible for health insurance, conditional on being in a firm that offers it, based on weighted tabulations of data from the relevant supplements to the CPS. The average difference in column 7 is computed as the difference between the health insurance eligibility rate for workers in peripheral jobs (column 3 ) and the eligibility rate for workers in core jobs (column 2). The adjusted differences reported in column 8 are the coefficients on a peripheral job dummy variable from separate OLS regressions for each year of the health insurance eligibility indicator on the peripheral job dummy variable and controls for age, education, sex, race, marital status, and the interaction of sex and marital status. The regression adjustment for the "all" sample includes survey dummy variables as well. All counts are weighted by the CPS supplement weights. The sample includes all private sector workers ages 20-64 who are not self-employed. 
Table 6

Fraction Covered by Employer-Provided Health Insurance Conditional on Eligibility

(Takeup Rate)

by Year and Job Type

Private Sector Workers Ages 20-64

\begin{tabular}{|c|c|c|c|c|c|c|c|c|c|}
\hline Year & $\begin{array}{c}\text { Sample } \\
\text { Size }\end{array}$ & $\begin{array}{c}\text { All Jobs } \\
\text { Average } \\
(1) \\
\end{array}$ & $\begin{array}{c}\text { Full-time } \\
\text { Old (Core) } \\
\text { Jobs Average } \\
(2)\end{array}$ & $\begin{array}{c}\text { Peripheral } \\
\text { Jobs } \\
\text { Average } \\
(3) \\
\end{array}$ & $\begin{array}{c}\text { Full-time } \\
\text { New Jobs } \\
\text { Average } \\
(4)\end{array}$ & $\begin{array}{c}\text { Part-time } \\
\text { Old Jobs } \\
\text { Average } \\
(5)\end{array}$ & $\begin{array}{c}\text { Part-time } \\
\text { New Jobs } \\
\text { Average } \\
(6)\end{array}$ & $\begin{array}{l}\text { Periph.-Core } \\
\text { Difference } \\
\text { Average } \\
(7) \\
\end{array}$ & $\begin{array}{c}\text { Periph.-Core } \\
\text { Difference } \\
\text { Adjusted } \\
(8) \\
\end{array}$ \\
\hline May88 & 12548 & $\begin{array}{c}0.886 \\
(0.002)\end{array}$ & $\begin{array}{c}0.926 \\
(0.002)\end{array}$ & $\begin{array}{c}0.731 \\
(0.006)\end{array}$ & $\begin{array}{c}0.827 \\
(0.007)\end{array}$ & $\begin{array}{c}0.598 \\
(0.013)\end{array}$ & $\begin{array}{c}0.353 \\
(0.026)\end{array}$ & $\begin{array}{l}-0.194 \\
(0.005)\end{array}$ & $\begin{array}{l}-0.173 \\
(0.007)\end{array}$ \\
\hline Apr93 & 11622 & $\begin{array}{c}0.876 \\
(0.002)\end{array}$ & $\begin{array}{c}0.908 \\
(0.002)\end{array}$ & $\begin{array}{c}0.722 \\
(0.007)\end{array}$ & $\begin{array}{c}0.808 \\
(0.008)\end{array}$ & $\begin{array}{c}0.629 \\
(0.013)\end{array}$ & $\begin{array}{c}0.437 \\
(0.032)\end{array}$ & $\begin{array}{l}-0.186 \\
(0.006)\end{array}$ & $\begin{array}{l}-0.165 \\
(0.008)\end{array}$ \\
\hline Feb95 & 25340 & $\begin{array}{c}0.855 \\
(0.003)\end{array}$ & $\begin{array}{c}0.891 \\
(0.003)\end{array}$ & $\begin{array}{c}0.698 \\
(0.009)\end{array}$ & $\begin{array}{c}0.776 \\
(0.011)\end{array}$ & $\begin{array}{c}0.593 \\
(0.018)\end{array}$ & $\begin{array}{c}0.449 \\
(0.039)\end{array}$ & $\begin{array}{l}-0.194 \\
(0.008)\end{array}$ & $\begin{array}{l}-0.179 \\
(0.006)\end{array}$ \\
\hline Feb97 & 22801 & $\begin{array}{c}0.850 \\
(0.003)\end{array}$ & $\begin{array}{c}0.883 \\
(0.003)\end{array}$ & $\begin{array}{c}0.705 \\
(0.009)\end{array}$ & $\begin{array}{c}0.779 \\
(0.010)\end{array}$ & $\begin{array}{c}0.605 \\
(0.018)\end{array}$ & $\begin{array}{c}0.440 \\
(0.041)\end{array}$ & $\begin{array}{l}-0.178 \\
(0.007)\end{array}$ & $\begin{array}{l}-0.161 \\
(0.006)\end{array}$ \\
\hline All & 72311 & $\begin{array}{c}0.871 \\
(0.001)\end{array}$ & $\begin{array}{c}0.906 \\
(0.001)\end{array}$ & $\begin{array}{c}0.718 \\
(0.004)\end{array}$ & $\begin{array}{c}0.804 \\
(0.004)\end{array}$ & $\begin{array}{c}0.609 \\
(0.007)\end{array}$ & $\begin{array}{c}0.405 \\
(0.016)\end{array}$ & $\begin{array}{l}-0.188 \\
(0.003)\end{array}$ & $\begin{array}{l}-0.170 \\
(0.003)\end{array}$ \\
\hline
\end{tabular}

Note: The numbers in parentheses are standard errors. The numbers in columns 1-6 are the fraction of workers in each group who are enrolled in their employer's health insurance plan, conditional on being eligible for it, based on weighted tabulations of data from the relevant supplements to the CPS. The average difference in column 7 is computed as the difference between the enrollment rate for workers in peripheral jobs (column 3) and the enrollment rate for workers in core jobs (column 2). The adjusted differences reported in column 8 are the coefficients on a peripheral job dummy variable from separate OLS regressions for each year of the health insurance enrollment indicator on the peripheral job dummy variable and controls for age, education, sex, race, marital status, and the interaction of sex and marital status. The regression adjustment for the "all" sample includes survey dummy variables as well. All counts are weighted by the CPS supplement weights. The sample includes all private sector workers ages 20-64 who are not self-employed. 
Table 7

Decomposition of Decline in Health Insurance Coverage: 1988-97

Private Sector Workers Ages 20-64

By Job Type

May 1988

\begin{tabular}{c|cccc|c} 
Year & $\begin{array}{c}\text { Full-time } \\
\text { Old }\end{array}$ & $\begin{array}{c}\text { Full-time } \\
\text { New }\end{array}$ & $\begin{array}{c}\text { Part-time } \\
\text { Old }\end{array}$ & $\begin{array}{c}\text { Part-time } \\
\text { New }\end{array}$ & Total \\
\hline Offering & 0.888 & 0.763 & 0.625 & 0.480 & 0.827 \\
Eligibility & 0.990 & 0.841 & 0.780 & 0.586 & 0.943 \\
Takeup & 0.926 & 0.827 & 0.598 & 0.353 & 0.886 \\
\hline Coverage & 0.813 & 0.529 & 0.291 & 0.098 & 0.691
\end{tabular}

February 1997

\begin{tabular}{c|cccc|c} 
Year & $\begin{array}{c}\text { Full-time } \\
\text { Old }\end{array}$ & $\begin{array}{c}\text { Full-time } \\
\text { New }\end{array}$ & $\begin{array}{c}\text { Part-time } \\
\text { Old }\end{array}$ & $\begin{array}{c}\text { Part-time } \\
\text { New }\end{array}$ & Total \\
\hline Offering & 0.889 & 0.759 & 0.675 & 0.568 & 0.835 \\
Eligibility & 0.982 & 0.781 & 0.671 & 0.355 & 0.912 \\
Takeup & 0.883 & 0.779 & 0.605 & 0.440 & 0.850 \\
\hline Coverage & 0.770 & 0.459 & 0.269 & 0.087 & 0.645
\end{tabular}

Change, May 1988 - February 1997

\begin{tabular}{c|cccc|c} 
Year & Full-time & Full-time & Part-time & Part-time & \\
& Old & New & Old & New & Total \\
\hline Offering & 0.001 & -0.004 & 0.050 & 0.088 & 0.008 \\
Eligibility & -0.008 & -0.060 & -0.109 & -0.231 & -0.031 \\
Takeup & -0.043 & -0.048 & 0.007 & 0.087 & -0.036 \\
\hline Coverage & -0.043 & -0.070 & -0.022 & -0.011 & -0.046
\end{tabular}

Decomposition, within-group

\begin{tabular}{c|cccc|c} 
Year & Full-time & Full-time & Part-time & Part-time & \\
& Old & New & Old & New & Total \\
\hline Offering & 0.001 & -0.003 & 0.023 & 0.018 & 0.007 \\
Eligibility & -0.007 & -0.038 & -0.041 & -0.039 & -0.023 \\
Takeup & -0.038 & -0.031 & 0.003 & 0.024 & -0.028 \\
Covariance terms & 0.000 & 0.003 & -0.004 & -0.014 & 0.000 \\
\hline Total & -0.043 & -0.069 & -0.018 & -0.011 & -0.044
\end{tabular}

(Table continues on next page.) 
Table 7 (continued)

Decomposition of Decline in Health Insurance Coverage: 1988-97

Private Sector Workers Ages 20-64

By Job Type

Decomposition of overall changes, weighted by employment share

\begin{tabular}{c|cccc|c} 
Year & Full-time & Full-time & Part-time & Part-time & \\
& Old & New & Old & New & Total \\
\hline Offering & 0.001 & -0.001 & 0.004 & 0.003 & 0.007 \\
Eligibility & -0.004 & -0.007 & -0.008 & -0.007 & -0.026 \\
Takeup & -0.024 & -0.006 & 0.001 & 0.003 & -0.026 \\
Covariance terms & & & & & 0.000 \\
\hline Total & -0.027 & -0.013 & -0.003 & -0.001 & -0.044 \\
\hline Employment Share & 0.712 & 0.150 & 0.095 & 0.044 & 1.000
\end{tabular}

Note: The numbers in the first two panels are based on tables 4-7. The estimates in the third panel are computed as the differences between the first two panels. The decompositions in the fourth and fifth panels are based on our estimates from the CPS as described in the text. The employment shares in the fifth panel are computed based on weighted averages of the cell counts from the May 1988, April 1993, February 1995 and February 1997 CPS samples. 
Table 8

Fraction of Workers Married to Another Worker

by Year and Job Type

Private Sector Workers Ages 20-64

\begin{tabular}{|c|c|c|c|c|c|c|c|c|c|}
\hline Year & $\begin{array}{c}\text { Sample } \\
\text { Size }\end{array}$ & $\begin{array}{c}\text { All Jobs } \\
\text { Average } \\
(1)\end{array}$ & $\begin{array}{c}\text { Full-time } \\
\text { Old (Core) } \\
\text { Jobs Average } \\
(2)\end{array}$ & $\begin{array}{l}\text { Peripheral } \\
\text { Jobs } \\
\text { Average } \\
(3) \\
\end{array}$ & $\begin{array}{c}\text { Full-time } \\
\text { New Jobs } \\
\text { Average } \\
(4)\end{array}$ & $\begin{array}{c}\text { Part-time } \\
\text { Old Jobs } \\
\text { Average } \\
\quad(5)\end{array}$ & $\begin{array}{c}\text { Part-time } \\
\text { New Jobs } \\
\text { Average } \\
(6)\end{array}$ & $\begin{array}{c}\text { Periph.-Core } \\
\text { Difference } \\
\text { Average } \\
(7)\end{array}$ & $\begin{array}{c}\text { Periph.-Core } \\
\text { Difference } \\
\text { Adjusted } \\
(8)\end{array}$ \\
\hline May88 & 15912 & $\begin{array}{c}0.467 \\
(0.003)\end{array}$ & $\begin{array}{c}0.475 \\
(0.003)\end{array}$ & $\begin{array}{c}0.448 \\
(0.005)\end{array}$ & $\begin{array}{c}0.376 \\
(0.007)\end{array}$ & $\begin{array}{c}0.581 \\
(0.010)\end{array}$ & $\begin{array}{c}0.464 \\
(0.014)\end{array}$ & $\begin{array}{l}-0.027 \\
(0.006)\end{array}$ & $\begin{array}{c}0.009 \\
(0.009)\end{array}$ \\
\hline Apr93 & 15641 & $\begin{array}{c}0.460 \\
(0.003)\end{array}$ & $\begin{array}{c}0.474 \\
(0.003)\end{array}$ & $\begin{array}{c}0.421 \\
(0.005)\end{array}$ & $\begin{array}{c}0.374 \\
(0.008)\end{array}$ & $\begin{array}{c}0.510 \\
(0.009)\end{array}$ & $\begin{array}{c}0.354 \\
(0.013)\end{array}$ & $\begin{array}{l}-0.054 \\
(0.006)\end{array}$ & $\begin{array}{l}-0.008 \\
(0.009)\end{array}$ \\
\hline Feb95 & 33454 & $\begin{array}{c}0.475 \\
(0.004)\end{array}$ & $\begin{array}{c}0.491 \\
(0.005)\end{array}$ & $\begin{array}{c}0.436 \\
(0.007)\end{array}$ & $\begin{array}{c}0.377 \\
(0.010)\end{array}$ & $\begin{array}{c}0.545 \\
(0.012)\end{array}$ & $\begin{array}{c}0.403 \\
(0.018)\end{array}$ & $\begin{array}{l}-0.055 \\
(0.009)\end{array}$ & $\begin{array}{c}0.008 \\
(0.006)\end{array}$ \\
\hline Feb97 & 29884 & $\begin{array}{c}0.476 \\
(0.004) \\
\end{array}$ & $\begin{array}{c}0.495 \\
(0.005) \\
\end{array}$ & $\begin{array}{c}0.430 \\
(0.007) \\
\end{array}$ & $\begin{array}{c}0.378 \\
(0.010) \\
\end{array}$ & $\begin{array}{c}0.533 \\
(0.012) \\
\end{array}$ & $\begin{array}{c}0.378 \\
(0.018) \\
\end{array}$ & $\begin{array}{l}-0.065 \\
(0.009) \\
\end{array}$ & $\begin{array}{l}-0.013 \\
(0.006) \\
\end{array}$ \\
\hline All & 94891 & $\begin{array}{c}0.467 \\
(0.002)\end{array}$ & $\begin{array}{c}0.481 \\
(0.002)\end{array}$ & $\begin{array}{c}0.434 \\
(0.003)\end{array}$ & $\begin{array}{c}0.376 \\
(0.004)\end{array}$ & $\begin{array}{c}0.540 \\
(0.007)\end{array}$ & $\begin{array}{c}0.401 \\
(0.008)\end{array}$ & $\begin{array}{l}-0.047 \\
(0.004)\end{array}$ & $\begin{array}{l}-0.003 \\
(0.004)\end{array}$ \\
\hline
\end{tabular}

Note: The numbers in parentheses are standard errors. The numbers in columns 1-6 are the fraction of workers in each group who are married to another worker based on weighted tabulations of data from the relevant supplements to the CPS. The average difference in column 7 is computed as the difference between the working-spouse rate for workers in peripheral jobs (column 3) and the working-spouse rate for workers in core jobs (column 2). The adjusted differences reported in column 8 are the coefficients on a peripheral job dummy variable from separate OLS regressions for each year of the working spouse indicator on the peripheral job dummy variable and controls for age, education, sex, and race. The regression adjustment for the "all" sample includes survey dummy variables as well. All counts are weighted by the CPS supplement weights. The sample includes all private sector workers ages $20-64$ who are not self-employed. 
Table 9

Fraction of Workers with Spouse in Core (Old Full-Time) Job, Conditional on Being in a Two-Worker Couple by Year and Job Type

Private Sector Workers Ages 20-64

\begin{tabular}{|c|c|c|c|c|c|c|c|c|c|}
\hline Year & $\begin{array}{c}\text { Sample } \\
\text { Size }\end{array}$ & $\begin{array}{c}\text { All Jobs } \\
\text { Average } \\
(1) \\
\end{array}$ & $\begin{array}{c}\text { Full-time } \\
\text { Old (Core) } \\
\text { Jobs Average } \\
(2)\end{array}$ & $\begin{array}{c}\text { Peripheral } \\
\text { Jobs } \\
\text { Average } \\
(3) \\
\end{array}$ & $\begin{array}{c}\text { Full-time } \\
\text { New Jobs } \\
\text { Average } \\
(4)\end{array}$ & $\begin{array}{c}\text { Part-time } \\
\text { Old Jobs } \\
\text { Average } \\
\quad(5) \\
\end{array}$ & $\begin{array}{l}\text { Part-time } \\
\text { New Jobs } \\
\text { Average } \\
(6)\end{array}$ & $\begin{array}{c}\text { Periph.-Core } \\
\text { Difference } \\
\text { Average } \\
(7) \\
\end{array}$ & $\begin{array}{c}\text { Periph.-Core } \\
\text { Difference } \\
\text { Adjusted } \\
(8) \\
\end{array}$ \\
\hline May88 & 6575 & $\begin{array}{c}0.717 \\
(0.004)\end{array}$ & $\begin{array}{c}0.716 \\
(0.005)\end{array}$ & $\begin{array}{c}0.719 \\
(0.007)\end{array}$ & $\begin{array}{c}0.608 \\
(0.012)\end{array}$ & $\begin{array}{c}0.850 \\
(0.010)\end{array}$ & $\begin{array}{c}0.768 \\
(0.019)\end{array}$ & $\begin{array}{c}0.003 \\
(0.009)\end{array}$ & $\begin{array}{l}-0.050 \\
(0.012)\end{array}$ \\
\hline Apr93 & 6398 & $\begin{array}{c}0.744 \\
(0.004)\end{array}$ & $\begin{array}{c}0.741 \\
(0.005)\end{array}$ & $\begin{array}{c}0.750 \\
(0.008)\end{array}$ & $\begin{array}{c}0.651 \\
(0.013)\end{array}$ & $\begin{array}{c}0.862 \\
(0.009)\end{array}$ & $\begin{array}{c}0.721 \\
(0.021)\end{array}$ & $\begin{array}{c}0.009 \\
(0.009)\end{array}$ & $\begin{array}{l}-0.042 \\
(0.013)\end{array}$ \\
\hline Feb95 & 15263 & $\begin{array}{c}0.716 \\
(0.005)\end{array}$ & $\begin{array}{c}0.719 \\
(0.006)\end{array}$ & $\begin{array}{c}0.707 \\
(0.010)\end{array}$ & $\begin{array}{c}0.606 \\
(0.016)\end{array}$ & $\begin{array}{c}0.819 \\
(0.012)\end{array}$ & $\begin{array}{c}0.704 \\
(0.025)\end{array}$ & $\begin{array}{l}-0.012 \\
(0.011)\end{array}$ & $\begin{array}{l}-0.062 \\
(0.008)\end{array}$ \\
\hline Feb97 & 13615 & $\begin{array}{c}0.732 \\
(0.005) \\
\end{array}$ & $\begin{array}{c}0.730 \\
(0.006) \\
\end{array}$ & $\begin{array}{c}0.736 \\
(0.010) \\
\end{array}$ & $\begin{array}{c}0.644 \\
(0.016) \\
\end{array}$ & $\begin{array}{c}0.842 \\
(0.012) \\
\end{array}$ & $\begin{array}{c}0.723 \\
(0.027) \\
\end{array}$ & $\begin{array}{c}0.006 \\
(0.011) \\
\end{array}$ & $\begin{array}{l}-0.038 \\
(0.009)\end{array}$ \\
\hline All & 41851 & $\begin{array}{c}0.728 \\
(0.002)\end{array}$ & $\begin{array}{c}0.728 \\
(0.003)\end{array}$ & $\begin{array}{c}0.729 \\
(0.004)\end{array}$ & $\begin{array}{c}0.626 \\
(0.007)\end{array}$ & $\begin{array}{c}0.846 \\
(0.005)\end{array}$ & $\begin{array}{c}0.735 \\
(0.011)\end{array}$ & $\begin{array}{c}0.002 \\
(0.005)\end{array}$ & $\begin{array}{l}-0.048 \\
(0.005)\end{array}$ \\
\hline
\end{tabular}

Note: The numbers in parentheses are standard errors. The numbers in columns 1-6 are the fraction of workers in each group whose spouse is a core worker based on weighted tabulations of data from the relevant supplements to the CPS. The average difference in column 7 is computed as the difference between the spouse-is-core-worker rate for workers in peripheral jobs (column 3) and the spouse-is-core-worker rate for workers in core jobs (column 2). The adjusted differences reported in column 8 are the coefficients on a peripheral job dummy variable from separate OLS regressions for each year of the spouse-is-coreworker indicator on the peripheral job dummy variable and controls for age, education, sex, and race. The regression adjustment for the "all" sample includes survey dummy variables as well. All counts are weighted by the CPS supplement weights. The sample includes all private sector workers ages $20-64$ who are not self-employed. 
Table 10

Fraction of Workers with Coverage as a Dependent on a Spouse's Employer-Sponsored Health Insurance Policy

(Spousal Coverage Rate)

by Year and Job Type

Private Sector Workers Ages 20-64

\begin{tabular}{|c|c|c|c|c|c|c|c|c|c|}
\hline Year & $\begin{array}{c}\text { Sample } \\
\text { Size }\end{array}$ & $\begin{array}{c}\text { All Jobs } \\
\text { Average } \\
(1) \\
\end{array}$ & $\begin{array}{c}\text { Full-time } \\
\text { Old (Core) } \\
\text { Jobs Average } \\
(2)\end{array}$ & $\begin{array}{c}\text { Peripheral } \\
\text { Jobs } \\
\text { Average } \\
(3) \\
\end{array}$ & $\begin{array}{c}\text { Full-time } \\
\text { New Jobs } \\
\text { Average } \\
(4)\end{array}$ & $\begin{array}{c}\text { Part-time } \\
\text { Old Jobs } \\
\text { Average } \\
(5)\end{array}$ & $\begin{array}{c}\text { Part-time } \\
\text { New Jobs } \\
\text { Average } \\
(6)\end{array}$ & $\begin{array}{l}\text { Periph.-Core } \\
\text { Difference } \\
\text { Average } \\
(7) \\
\end{array}$ & $\begin{array}{c}\text { Periph.-Core } \\
\text { Difference } \\
\text { Adjusted } \\
(8) \\
\end{array}$ \\
\hline May88 & 14737 & $\begin{array}{c}0.094 \\
(0.002)\end{array}$ & $\begin{array}{c}0.059 \\
(0.002)\end{array}$ & $\begin{array}{c}0.177 \\
(0.004)\end{array}$ & $\begin{array}{c}0.095 \\
(0.004)\end{array}$ & $\begin{array}{c}0.304 \\
(0.009)\end{array}$ & $\begin{array}{c}0.260 \\
(0.012)\end{array}$ & $\begin{array}{c}0.118 \\
(0.004)\end{array}$ & $\begin{array}{c}0.115 \\
(0.005)\end{array}$ \\
\hline Apr93 & 14557 & $\begin{array}{c}0.107 \\
(0.002)\end{array}$ & $\begin{array}{c}0.080 \\
(0.002)\end{array}$ & $\begin{array}{c}0.178 \\
(0.004)\end{array}$ & $\begin{array}{c}0.109 \\
(0.005)\end{array}$ & $\begin{array}{c}0.275 \\
(0.008)\end{array}$ & $\begin{array}{c}0.177 \\
(0.011)\end{array}$ & $\begin{array}{c}0.098 \\
(0.004)\end{array}$ & $\begin{array}{c}0.105 \\
(0.006)\end{array}$ \\
\hline Feb95 & 32506 & $\begin{array}{c}0.107 \\
(0.002)\end{array}$ & $\begin{array}{c}0.080 \\
(0.003)\end{array}$ & $\begin{array}{c}0.171 \\
(0.006)\end{array}$ & $\begin{array}{c}0.097 \\
(0.006)\end{array}$ & $\begin{array}{c}0.272 \\
(0.011)\end{array}$ & $\begin{array}{c}0.209 \\
(0.015)\end{array}$ & $\begin{array}{c}0.092 \\
(0.005)\end{array}$ & $\begin{array}{c}0.095 \\
(0.004)\end{array}$ \\
\hline Feb97 & 28921 & $\begin{array}{c}0.109 \\
(0.002)\end{array}$ & $\begin{array}{c}0.082 \\
(0.002)\end{array}$ & $\begin{array}{c}0.175 \\
(0.006)\end{array}$ & $\begin{array}{c}0.109 \\
(0.006)\end{array}$ & $\begin{array}{c}0.275 \\
(0.011)\end{array}$ & $\begin{array}{c}0.186 \\
(0.015)\end{array}$ & $\begin{array}{c}0.093 \\
(0.005)\end{array}$ & $\begin{array}{c}0.097 \\
(0.004)\end{array}$ \\
\hline All & 90721 & $\begin{array}{c}0.103 \\
(0.001)\end{array}$ & $\begin{array}{c}0.076 \\
(0.001)\end{array}$ & $\begin{array}{c}0.176 \\
(0.002)\end{array}$ & $\begin{array}{c}0.104 \\
(0.003)\end{array}$ & $\begin{array}{c}0.288 \\
(0.005)\end{array}$ & $\begin{array}{c}0.213 \\
(0.007)\end{array}$ & $\begin{array}{c}0.104 \\
(0.002)\end{array}$ & $\begin{array}{c}0.107 \\
(0.002)\end{array}$ \\
\hline
\end{tabular}

Note: The numbers in parentheses are standard errors. The numbers in columns 1-6 are the fraction of workers in each group with employer-sponsored health insurance coverage as a dependent on a spouse's policy based on weighted tabulations of data from the relevant supplements to the CPS. The average difference in column 7 is computed as the difference between the spousal health insurance coverage rate for workers in peripheral jobs (column 3) and the spousal coverage rate for workers in core jobs (column 2). The adjusted differences reported in column 8 are the coefficients on a peripheral job dummy variable from separate OLS regressions for each year of the spousal coverage indicator on the peripheral job dummy variable and controls for age, education, sex, and race. The regression adjustment for the "all" sample includes survey dummy variables as well. All counts are weighted by the CPS supplement weights. The sample includes all private sector workers ages 20-64 who are not self-employed. 
Table 11

Fraction of Workers with any Employer-Sponsored Health Insurance Coverage

by Year and Job Type

Private Sector Workers Ages 20-64

\begin{tabular}{|c|c|c|c|c|c|c|c|c|c|}
\hline Year & $\begin{array}{c}\text { Sample } \\
\text { Size }\end{array}$ & $\begin{array}{c}\text { All Jobs } \\
\text { Average } \\
\text { (1) }\end{array}$ & $\begin{array}{c}\text { Full-time } \\
\text { Old (Core) } \\
\text { Jobs Average } \\
\text { (2) }\end{array}$ & $\begin{array}{l}\text { Peripheral } \\
\text { Jobs } \\
\text { Average } \\
\text { (3) }\end{array}$ & $\begin{array}{c}\text { Full-time } \\
\text { New Jobs } \\
\text { Average } \\
\text { (4) }\end{array}$ & $\begin{array}{c}\text { Part-time } \\
\text { Old Jobs } \\
\text { Average } \\
\text { (5) }\end{array}$ & $\begin{array}{c}\text { Part-time } \\
\text { New Jobs } \\
\text { Average } \\
\text { (6) }\end{array}$ & $\begin{array}{c}\text { Periph.-Core } \\
\text { Difference } \\
\text { Average } \\
\text { (7) }\end{array}$ & $\begin{array}{c}\text { Periph.-Core } \\
\text { Difference } \\
\text { Adjusted } \\
\text { (8) }\end{array}$ \\
\hline May88 & 14737 & $\begin{array}{c}0.784 \\
(0.003)\end{array}$ & $\begin{array}{c}0.870 \\
(0.002)\end{array}$ & $\begin{array}{c}0.575 \\
(0.005)\end{array}$ & $\begin{array}{c}0.625 \\
(0.007)\end{array}$ & $\begin{array}{c}0.585 \\
(0.010)\end{array}$ & $\begin{array}{c}0.360 \\
(0.013)\end{array}$ & $\begin{array}{l}-0.295 \\
(0.005)\end{array}$ & $\begin{array}{l}-0.262 \\
(0.007)\end{array}$ \\
\hline Apr93 & 14557 & $\begin{array}{c}0.754 \\
(0.002)\end{array}$ & $\begin{array}{c}0.856 \\
(0.002)\end{array}$ & $\begin{array}{c}0.503 \\
(0.005)\end{array}$ & $\begin{array}{c}0.563 \\
(0.008)\end{array}$ & $\begin{array}{c}0.560 \\
(0.009)\end{array}$ & $\begin{array}{c}0.260 \\
(0.013)\end{array}$ & $\begin{array}{l}-0.342 \\
(0.005)\end{array}$ & $\begin{array}{l}-0.299 \\
(0.007)\end{array}$ \\
\hline Feb95 & 32506 & $\begin{array}{c}0.748 \\
(0.003)\end{array}$ & $\begin{array}{c}0.850 \\
(0.003)\end{array}$ & $\begin{array}{c}0.505 \\
(0.007)\end{array}$ & $\begin{array}{c}0.546 \\
(0.010)\end{array}$ & $\begin{array}{c}0.535 \\
(0.012)\end{array}$ & $\begin{array}{c}0.304 \\
(0.017)\end{array}$ & $\begin{array}{l}-0.345 \\
(0.007)\end{array}$ & $\begin{array}{l}-0.314 \\
(0.005)\end{array}$ \\
\hline Feb97 & 28921 & $\begin{array}{c}0.756 \\
(0.003) \\
\end{array}$ & $\begin{array}{c}0.853 \\
(0.003) \\
\end{array}$ & $\begin{array}{c}0.519 \\
(0.007) \\
\end{array}$ & $\begin{array}{c}0.569 \\
(0.010) \\
\end{array}$ & $\begin{array}{c}0.547 \\
(0.012) \\
\end{array}$ & $\begin{array}{c}0.274 \\
(0.017) \\
\end{array}$ & $\begin{array}{l}-0.335 \\
(0.007)\end{array}$ & $\begin{array}{l}-0.298 \\
(0.005)\end{array}$ \\
\hline All & 90721 & $\begin{array}{c}0.763 \\
(0.001)\end{array}$ & $\begin{array}{c}0.859 \\
(0.001)\end{array}$ & $\begin{array}{c}0.529 \\
(0.003)\end{array}$ & $\begin{array}{c}0.583 \\
(0.004)\end{array}$ & $\begin{array}{c}0.560 \\
(0.005)\end{array}$ & $\begin{array}{c}0.302 \\
(0.007)\end{array}$ & $\begin{array}{l}-0.326 \\
(0.003)\end{array}$ & $\begin{array}{l}-0.290 \\
(0.003)\end{array}$ \\
\hline
\end{tabular}

Note: The numbers in parentheses are standard errors. The numbers in columns 1-6 are the fraction of workers in each group with any employer-sponsored health insurance coverage based on weighted tabulations of data from the relevant supplements to the CPS. (They are also the sum of the numbers in the corresponding cells in table 2 and table 10.) The average difference in column 7 is computed as the difference between the rate of employer-sponsored health insurance coverage from any source for workers in peripheral jobs (column 3) and the coverage rate for workers in core jobs (column 2). The adjus ted differences reported in column 8 are the coefficients on a peripheral job dummy variable from separate OLS regressions for each year of the any health insurance coverage indicator on the peripheral job dummy variable and controls for age, education, sex, and race. The regression adjustment for the "all" sample includes survey dummy variables as well. All counts are weighted by the CPS supplement weights. The sample includes all private sector workers ages $20-64$ who are not self-employed. 
Table 12

Decomposition of Decline in Health Insurance Coverage: 1988-97

Private Sector Workers Ages 20-64

By Job Type

May 1988

\begin{tabular}{l|cccc|c} 
& $\begin{array}{c}\text { Full-time } \\
\text { Old }\end{array}$ & $\begin{array}{c}\text { Full-time } \\
\text { New }\end{array}$ & $\begin{array}{c}\text { Part-time } \\
\text { Old }\end{array}$ & $\begin{array}{c}\text { Part-time } \\
\text { New }\end{array}$ & Total \\
\hline Offering & 0.887 & 0.763 & 0.623 & 0.479 & 0.827 \\
Eligibility & 0.990 & 0.839 & 0.779 & 0.580 & 0.943 \\
Takeup & 0.927 & 0.829 & 0.601 & 0.356 & 0.888 \\
\hline Own Coverage & 0.814 & 0.531 & 0.292 & 0.099 & 0.692 \\
Spouse Coverage & 0.060 & 0.098 & 0.311 & 0.267 & 0.096 \\
\hline Any Coverage & 0.873 & 0.629 & 0.603 & 0.366 & 0.788
\end{tabular}

February 1997

\begin{tabular}{l|cccc|c} 
& $\begin{array}{c}\text { Full-time } \\
\text { Old }\end{array}$ & $\begin{array}{c}\text { Full-time } \\
\text { New }\end{array}$ & $\begin{array}{c}\text { Part-time } \\
\text { Old }\end{array}$ & $\begin{array}{c}\text { Part-time } \\
\text { New }\end{array}$ & Total \\
\hline Offering & 0.889 & 0.759 & 0.675 & 0.566 & 0.835 \\
Eligibility & 0.982 & 0.781 & 0.670 & 0.352 & 0.913 \\
Takeup & 0.882 & 0.775 & 0.595 & 0.429 & 0.848 \\
\hline Own Coverage & 0.770 & 0.460 & 0.271 & 0.088 & 0.646 \\
Spouse Coverage & 0.083 & 0.111 & 0.281 & 0.195 & 0.111 \\
\hline Any Coverage & 0.853 & 0.571 & 0.552 & 0.283 & 0.757
\end{tabular}

Change, May 88 - February 97

\begin{tabular}{l|cccc|c} 
& Full-time & Full-time & Part-time & Part-time & \\
& Old & New & Old & New & Total \\
\hline Offering & 0.002 & -0.004 & 0.052 & 0.087 & 0.008 \\
Eligibility & -0.008 & -0.058 & -0.109 & -0.228 & -0.030 \\
Takeup & -0.045 & -0.054 & -0.006 & 0.073 & -0.040 \\
\hline Own Coverage & -0.044 & -0.071 & -0.021 & -0.011 & -0.046 \\
Spouse Coverage & 0.023 & 0.013 & -0.030 & -0.072 & 0.015 \\
\hline Any Coverage & -0.020 & -0.058 & -0.051 & -0.083 & -0.031
\end{tabular}

Decomposition, within-group

\begin{tabular}{l|cccc|c} 
& Full-time & Full-time & Part-time & Part-time & \\
& Old & New & Old & New & Total \\
\hline Offering & 0.002 & -0.003 & 0.024 & 0.018 & 0.007 \\
Eligibility & -0.007 & -0.037 & -0.041 & -0.039 & -0.022 \\
Takeup & -0.040 & -0.035 & -0.003 & 0.020 & -0.031 \\
Covariance & 0.000 & 0.003 & -0.003 & -0.013 & 0.000 \\
Spouse Coverage & 0.023 & 0.013 & -0.030 & -0.072 & 0.015 \\
\hline Total & -0.021 & -0.058 & -0.053 & -0.085 & -0.031
\end{tabular}

(Table continues on next page.) 
Table 12 (continued)

Decomposition of Decline in Health Insurance Coverage: 1988-97

Private Sector Workers Ages 20-64

By Job Type

Decomposition of overall changes, weighted by employment share

\begin{tabular}{l|rrrr|r} 
& Full-time & Full-time & Part-time & Part-time & \\
& Old & New & Old & New & Total \\
\hline Offering & 0.001 & 0.000 & 0.002 & 0.001 & 0.004 \\
Eligibility & -0.005 & -0.005 & -0.004 & -0.002 & -0.016 \\
Takeup & -0.028 & -0.005 & 0.000 & 0.001 & -0.033 \\
Covariance & 0.000 & 0.000 & 0.000 & -0.001 & -0.000 \\
Spouse Coverage & 0.016 & 0.002 & -0.002 & -0.003 & 0.012 \\
\hline Total & -0.015 & -0.009 & -0.005 & -0.004 & -0.032 \\
\hline Employment Share & 0.713 & 0.149 & 0.095 & 0.043 & 1.000
\end{tabular}

Note: The numbers in the first two panels are based on tables 4-7 and tables 11-12. The estimates in the third panel are computed as the differences between the first two panels. The decompositions in the fourth and fifth panels are based on our estimates from the CPS as described in the text. The employment shares in the fifth panel are computed based on weighted averages of the cell counts from the May 1988, April 1993, February 1995 and February 1997 CPS samples. 
Table 13

Fraction Covered by Health Insurance Provided by Their Employer

by Year and Educational Attainment

Private Sector Workers Ages 20-64

All Job Types (Core and Peripheral)

\begin{tabular}{|c|c|c|c|c|c|c|c|c|c|}
\hline \multirow[t]{3}{*}{ Year } & \multirow{3}{*}{$\begin{array}{l}\text { Sample } \\
\text { Size }\end{array}$} & \multirow{3}{*}{$\begin{array}{c}\text { All Jobs } \\
\text { Average } \\
(1)\end{array}$} & \multirow{3}{*}{$\begin{array}{c}\text { College } \\
\text { Graduates } \\
\text { (2) }\end{array}$} & \multirow{3}{*}{$\begin{array}{l}\text { Less than } 4 \\
\text { Years of } \\
\text { College } \\
(3)\end{array}$} & \multicolumn{3}{|c|}{ Less than Four Years of College (Detail) } & \multirow{3}{*}{$\begin{array}{l}\text { Noncoll.-Coll } \\
\text { Difference } \\
\text { Average } \\
\text { (7) }\end{array}$} & \multirow{3}{*}{$\begin{array}{l}\text { Noncoll.-Coll } \\
\text { Difference } \\
\text { Adjusted } \\
(8)\end{array}$} \\
\hline & & & & & Less Than & High School & Some College & & \\
\hline & & & & & $\begin{array}{l}\text { High School } \\
\text { (4) }\end{array}$ & $\begin{array}{c}\text { Graduates } \\
\text { (5) }\end{array}$ & (6) & & \\
\hline \multirow[t]{2}{*}{ May79 } & 15706 & 0.719 & 0.806 & 0.704 & 0.673 & 0.714 & 0.713 & -0.102 & -0.063 \\
\hline & & $(0.003)$ & $(0.007)$ & $(0.004)$ & $(0.008)$ & $(0.005)$ & $(0.007)$ & (0.009) & $(0.010)$ \\
\hline \multirow[t]{2}{*}{ May83 } & 16970 & 0.706 & 0.809 & 0.681 & 0.633 & 0.703 & 0.675 & -0.127 & -0.093 \\
\hline & & $(0.003)$ & $(0.006)$ & $(0.003)$ & $(0.008)$ & $(0.005)$ & $(0.007)$ & $(0.008)$ & $(0.009)$ \\
\hline \multirow[t]{2}{*}{ May88 } & 16039 & 0.691 & 0.819 & 0.657 & 0.578 & 0.672 & 0.680 & -0.162 & -0.127 \\
\hline & & $(0.003)$ & $(0.005)$ & $(0.003)$ & $(0.009)$ & $(0.004)$ & $(0.006)$ & $(0.007)$ & $(0.009)$ \\
\hline \multirow[t]{2}{*}{ Apr93 } & 15711 & 0.647 & 0.774 & 0.611 & 0.471 & 0.627 & 0.638 & -0.164 & -0.134 \\
\hline & & $(0.003)$ & $(0.005)$ & $(0.003)$ & $(0.010)$ & $(0.005)$ & $(0.005)$ & $(0.007)$ & (0.009) \\
\hline \multirow[t]{2}{*}{ Feb95 } & 33693 & 0.641 & 0.760 & 0.604 & 0.486 & 0.619 & 0.623 & -0.156 & -0.133 \\
\hline & & $(0.004)$ & $(0.007)$ & $(0.005)$ & $(0.014)$ & $(0.007)$ & $(0.017)$ & (0.009) & $(0.006)$ \\
\hline \multirow[t]{2}{*}{ Feb97 } & 30003 & 0.645 & 0.760 & 0.608 & 0.502 & 0.616 & 0.632 & -0.152 & -0.129 \\
\hline & & $(0.004)$ & $(0.007)$ & $(0.005)$ & $(0.014)$ & $(0.007)$ & $(0.007)$ & $(0.009)$ & $(0.006)$ \\
\hline All & 95511 & $\begin{array}{c}0.678 \\
(0.001)\end{array}$ & $\begin{array}{c}0.790 \\
(0.002)\end{array}$ & $\begin{array}{c}0.649 \\
(0.002)\end{array}$ & $\begin{array}{c}0.584 \\
(0.004)\end{array}$ & $\begin{array}{c}0.666 \\
(0.002)\end{array}$ & $\begin{array}{c}0.658 \\
(0.003)\end{array}$ & $\begin{array}{l}-0.140 \\
(0.003)\end{array}$ & $\begin{array}{l}-0.116 \\
(0.003)\end{array}$ \\
\hline
\end{tabular}

Note: The numbers in parentheses are standard errors. The numbers in columns 1-6 are the fraction of workers in each group reporting that they are covered by their own employer-provided health insurance based on weighted tabulations of data from the relevant supplements to the CPS. The average difference in column 7 is computed as the difference between the health insurance coverage rate for workers with less than four years of college (column 3) and the coverage rate for all workers with four years of college or more (column 2). The adjusted differences reported in column 8 are the coefficients on a less-than-four-years-of-college dummy variable from separate OLS regressions for each year of the health insurance coverage indicator on the less-than-college dummy variable and controls for age, education, sex, race, marital status, and the interaction of sex and marital status. The regression adjustment for the "all" sample includes survey dummy variables as well. All counts are weighted by the CPS supplement weights. The sample includes all private sector workers ages 20-64 who are not self-employed. 
Table 14

Decomposition of Decline in Health Insurance Coverage: 1988-97

Private Sector Workers Ages 20-64

By Educational Attainment; All Job Types

May 1988

\begin{tabular}{c|cccc|c} 
Year & $\begin{array}{c}\text { Less Than } \\
\text { High School }\end{array}$ & $\begin{array}{c}\text { High School } \\
\text { Graduates }\end{array}$ & $\begin{array}{c}<4 \text { Years } \\
\text { College }\end{array}$ & $\begin{array}{c}\text { College } \\
\text { Graduates }\end{array}$ & Total \\
\hline Offering & 0.705 & 0.815 & 0.842 & 0.921 & 0.827 \\
Eligibility & 0.937 & 0.938 & 0.927 & 0.970 & 0.943 \\
Takeup & 0.876 & 0.881 & 0.874 & 0.918 & 0.886 \\
\hline Own Coverage & 0.579 & 0.673 & 0.682 & 0.821 & 0.692 \\
Spouse Coverage & 0.072 & 0.107 & 0.101 & 0.085 & 0.096 \\
\hline Any Coverage & 0.651 & 0.780 & 0.783 & 0.906 & 0.788
\end{tabular}

February 1997

\begin{tabular}{c|cccc|c} 
Year & $\begin{array}{c}\text { Less Than } \\
\text { High School }\end{array}$ & $\begin{array}{c}\text { High School } \\
\text { Graduates }\end{array}$ & $\begin{array}{c}<4 \text { Years } \\
\text { College }\end{array}$ & $\begin{array}{c}\text { College } \\
\text { Graduates }\end{array}$ & Total \\
\hline Offering & 0.664 & 0.811 & 0.851 & 0.917 & 0.835 \\
Eligibility & 0.902 & 0.909 & 0.891 & 0.947 & 0.913 \\
Takeup & 0.838 & 0.837 & 0.836 & 0.877 & 0.848 \\
\hline Own Coverage & 0.502 & 0.617 & 0.634 & 0.761 & 0.646 \\
Spouse Coverage & 0.063 & 0.116 & 0.117 & 0.115 & 0.111 \\
\hline Any Coverage & 0.565 & 0.733 & 0.751 & 0.876 & 0.757
\end{tabular}

Change, May 1988 - February 1997

\begin{tabular}{c|cccc|c} 
Year & $\begin{array}{c}\text { Less Than } \\
\text { High School }\end{array}$ & $\begin{array}{c}\text { High School } \\
\text { Graduates }\end{array}$ & $\begin{array}{c}<4 \text { Years } \\
\text { College }\end{array}$ & $\begin{array}{c}\text { College } \\
\text { Graduates }\end{array}$ & Total \\
\hline Offering & -0.041 & -0.004 & 0.009 & -0.004 & 0.008 \\
Eligibility & -0.035 & -0.029 & -0.036 & -0.023 & -0.030 \\
Takeup & -0.038 & -0.044 & -0.038 & -0.041 & -0.038 \\
\hline Own Coverage & -0.077 & -0.056 & -0.048 & -0.060 & -0.046 \\
Spouse Coverage & -0.009 & 0.009 & 0.016 & 0.030 & 0.015 \\
\hline Any Coverage & -0.086 & -0.047 & -0.032 & -0.029 & -0.031
\end{tabular}

Decomposition, within-group

\begin{tabular}{c|cccc|c} 
Year & $\begin{array}{c}\text { Less Than } \\
\text { High School }\end{array}$ & $\begin{array}{c}\text { High School } \\
\text { Graduates }\end{array}$ & $\begin{array}{c}<4 \text { Years } \\
\text { College }\end{array}$ & $\begin{array}{c}\text { College } \\
\text { Graduates }\end{array}$ & Total \\
\hline Offering & -0.034 & -0.003 & 0.007 & -0.004 & 0.007 \\
Eligibility & -0.022 & -0.021 & -0.026 & -0.019 & -0.022 \\
Takeup & -0.025 & -0.034 & -0.030 & -0.037 & -0.030 \\
Covariance & 0.004 & 0.001 & 0.001 & 0.001 & 0.000 \\
Spouse Coverage & -0.009 & 0.009 & 0.016 & 0.030 & 0.015 \\
\hline Total & -0.086 & -0.047 & -0.032 & -0.029 & -0.030
\end{tabular}

Note: The estimates in the third panel are computed as the differences between the first two panels. The decompositions in the fourth panel are based on our estimates from the CPS as described in the text. 
Table 15

Decomposition of Decline in Health Insurance Coverage: 1988-97

Private Sector Workers Ages 20-64

By Educational Attainment; Core Jobs Only

May 1988

\begin{tabular}{c|cccc|c} 
Year & $\begin{array}{c}\text { Less Than } \\
\text { High School }\end{array}$ & $\begin{array}{c}\text { High School } \\
\text { Graduates }\end{array}$ & $\begin{array}{c}<4 \text { Years } \\
\text { College }\end{array}$ & $\begin{array}{c}\text { College } \\
\text { Graduates }\end{array}$ & Total \\
\hline Offering & 0.789 & 0.876 & 0.908 & 0.953 & 0.887 \\
Eligibility & 0.987 & 0.991 & 0.983 & 0.995 & 0.990 \\
Takeup & 0.914 & 0.919 & 0.922 & 0.952 & 0.927 \\
\hline Own Coverage & 0.712 & 0.797 & 0.823 & 0.903 & 0.814 \\
Spouse Coverage & 0.046 & 0.069 & 0.065 & 0.046 & 0.060 \\
\hline Any Coverage & 0.758 & 0.867 & 0.888 & 0.949 & 0.874
\end{tabular}

February 1997

\begin{tabular}{c|cccl|c} 
Year & $\begin{array}{c}\text { Less Than } \\
\text { High School }\end{array}$ & $\begin{array}{c}\text { High School } \\
\text { Graduates }\end{array}$ & $\begin{array}{c}<4 \text { Years } \\
\text { College }\end{array}$ & $\begin{array}{c}\text { College } \\
\text { Graduates }\end{array}$ & Total \\
\hline Offering & 0.729 & 0.868 & 0.913 & 0.951 & 0.889 \\
Eligibility & 0.974 & 0.98 & 0.98 & 0.99 & 0.982 \\
Takeup & 0.865 & 0.872 & 0.88 & 0.904 & 0.882 \\
\hline Own Coverage & 0.614 & 0.742 & 0.787 & 0.851 & 0.77 \\
Spouse Coverage & 0.047 & 0.088 & 0.089 & 0.082 & 0.083 \\
\hline Any Coverage & 0.661 & 0.830 & 0.876 & 0.933 & 0.853
\end{tabular}

Change, May 1988 - February 1997

\begin{tabular}{c|cccc|c} 
Year & $\begin{array}{c}\text { Less Than } \\
\text { High School }\end{array}$ & $\begin{array}{c}\text { High School } \\
\text { Graduates }\end{array}$ & $\begin{array}{c}<4 \text { Years } \\
\text { College }\end{array}$ & $\begin{array}{c}\text { College } \\
\text { Graduates }\end{array}$ & Total \\
\hline Offering & -0.060 & -0.008 & 0.005 & -0.002 & 0.002 \\
Eligibility & -0.013 & -0.011 & -0.003 & -0.005 & -0.008 \\
Takeup & -0.049 & -0.047 & -0.042 & -0.048 & -0.045 \\
\hline Own Coverage & -0.098 & -0.055 & -0.036 & -0.052 & -0.044 \\
Spouse Coverage & 0.001 & 0.019 & 0.024 & 0.036 & 0.023 \\
\hline Any Coverage & -0.097 & -0.037 & -0.012 & -0.016 & -0.021
\end{tabular}

Decomposition, within-group

\begin{tabular}{c|cccc|c} 
Year & $\begin{array}{c}\text { Less Than } \\
\text { High School }\end{array}$ & $\begin{array}{c}\text { High School } \\
\text { Graduates }\end{array}$ & $\begin{array}{c}<4 \text { Years } \\
\text { College }\end{array}$ & $\begin{array}{c}\text { College } \\
\text { Graduates }\end{array}$ & Total \\
\hline Offering & -0.054 & -0.007 & 0.005 & -0.002 & 0.002 \\
Eligibility & -0.009 & -0.009 & -0.003 & -0.005 & -0.007 \\
Takeup & -0.038 & -0.041 & -0.037 & -0.046 & -0.040 \\
Covariance & 0.004 & 0.001 & 0.000 & 0.000 & 0.000 \\
Spouse Coverage & 0.001 & 0.019 & 0.024 & 0.036 & 0.023 \\
\hline Total & -0.097 & -0.037 & -0.012 & -0.016 & -0.021
\end{tabular}

Note: The estimates in the third panel are computed as the differences between the first two panels. The decompositions in the fourth panel are based on our estimates from the CPS as described in the text. 
Table 16

Decomposition of Decline in Health Insurance Coverage: 1988-97

Private Sector Workers Ages 20-64

By Educational Attainment; Peripheral Jobs Only

May 1988

\begin{tabular}{c|cccc|c} 
Year & $\begin{array}{c}\text { Less Than } \\
\text { High School }\end{array}$ & $\begin{array}{c}\text { High School } \\
\text { Graduates }\end{array}$ & $\begin{array}{c}<4 \text { Years } \\
\text { College }\end{array}$ & $\begin{array}{c}\text { College } \\
\text { Graduates }\end{array}$ & Total \\
\hline Offering & 0.520 & 0.664 & 0.703 & 0.829 & 0.681 \\
Eligibility & 0.770 & 0.767 & 0.778 & 0.887 & 0.796 \\
Takeup & 0.709 & 0.723 & 0.710 & 0.790 & 0.734 \\
\hline Own Coverage & 0.284 & 0.368 & 0.389 & 0.580 & 0.398 \\
Spouse Coverage & 0.130 & 0.203 & 0.176 & 0.200 & 0.185 \\
\hline Any Coverage & 0.414 & 0.571 & 0.564 & 0.781 & 0.583
\end{tabular}

February 1997

\begin{tabular}{c|cccc|c} 
Year & $\begin{array}{c}\text { Less Than } \\
\text { High School }\end{array}$ & $\begin{array}{c}\text { High School } \\
\text { Graduates }\end{array}$ & $\begin{array}{c}<4 \text { Years } \\
\text { College }\end{array}$ & $\begin{array}{c}\text { College } \\
\text { Graduates }\end{array}$ & Total \\
\hline Offering & 0.518 & 0.659 & 0.725 & 0.821 & 0.703 \\
Eligibility & 0.674 & 0.657 & 0.657 & 0.803 & 0.696 \\
Takeup & 0.715 & 0.658 & 0.668 & 0.770 & 0.698 \\
\hline Own Coverage & 0.250 & 0.286 & 0.320 & 0.509 & 0.343 \\
Spouse Coverage & 0.098 & 0.191 & 0.176 & 0.208 & 0.18 \\
\hline Any Coverage & 0.348 & 0.476 & 0.494 & 0.716 & 0.522
\end{tabular}

Change, May 1988 - February 1997

\begin{tabular}{c|cccc|c} 
Year & $\begin{array}{c}\text { Less Than } \\
\text { High School }\end{array}$ & $\begin{array}{c}\text { High School } \\
\text { Graduates }\end{array}$ & $\begin{array}{c}<4 \text { Years } \\
\text { College }\end{array}$ & $\begin{array}{c}\text { College } \\
\text { Graduates }\end{array}$ & Total \\
\hline Offering & -0.002 & -0.005 & 0.022 & -0.008 & 0.022 \\
Eligibility & -0.096 & -0.110 & -0.121 & -0.084 & -0.100 \\
Takeup & 0.006 & -0.065 & -0.042 & -0.020 & -0.036 \\
\hline Own Coverage & -0.034 & -0.082 & -0.069 & -0.071 & -0.055 \\
Spouse Coverage & -0.032 & -0.012 & 0.000 & 0.008 & -0.005 \\
\hline Any Coverage & -0.066 & -0.095 & -0.070 & -0.065 & -0.061
\end{tabular}

Decomposition, within-group

\begin{tabular}{c|cccc|c} 
Year & $\begin{array}{c}\text { Less Than } \\
\text { High School }\end{array}$ & $\begin{array}{c}\text { High School } \\
\text { Graduates }\end{array}$ & $\begin{array}{c}<4 \text { Years } \\
\text { College }\end{array}$ & $\begin{array}{c}\text { College } \\
\text { Graduates }\end{array}$ & Total \\
\hline Offering & -0.001 & -0.003 & 0.012 & -0.006 & 0.013 \\
Eligibility & -0.035 & -0.053 & -0.060 & -0.055 & -0.050 \\
Takeup & 0.002 & -0.033 & -0.023 & -0.015 & -0.020 \\
Covariance & 0.000 & 0.005 & 0.001 & 0.002 & 0.000 \\
Spouse Coverage & -0.032 & -0.012 & 0.000 & 0.008 & -0.005 \\
\hline Total & -0.066 & -0.095 & -0.070 & -0.065 & -0.061
\end{tabular}

Note: The estimates in the third panel are computed as the differences between the first two panels. The decompositions in the fourth panel are based on our estimates from the CPS as described in the text. 


\title{
Appendix Tables
}

\author{
to accompany
}

Recent Trends in Employer-Sponsored Health Insurance Coverage:

Are Bad Jobs Getting Worse?

\author{
by \\ Henry S. Farber ${ }^{*}$ \\ Princeton University \\ and \\ Helen Levy \\ Robert Wood Johnson Scholars in Health Policy Program \\ University of California--Berkeley
}

July 1998

\footnotetext{
* Address correspondence to: Henry Farber, Industrial Relations Section, Firestone Library, Princeton University, Princeton NJ 08544; farber@princeton.edu.
} 
Table A1

Fraction Whose Employers Offer Health Insurance Coverage to at least Some Employees

by Year and Educational Attainment

Private Sector Workers Ages 20-64

All Job Types (Core and Peripheral)

\begin{tabular}{|c|c|c|c|c|c|c|c|c|c|}
\hline \multirow[t]{3}{*}{ Year } & \multirow{3}{*}{$\begin{array}{c}\text { Sample } \\
\text { Size }\end{array}$} & \multirow{3}{*}{$\begin{array}{c}\text { All Jobs } \\
\text { Average } \\
\text { (1) }\end{array}$} & \multirow{3}{*}{$\begin{array}{l}\text { College } \\
\text { Graduates } \\
\text { (2) }\end{array}$} & \multirow{3}{*}{$\begin{array}{c}\text { Less than } 4 \\
\text { Years of } \\
\text { College } \\
(3)\end{array}$} & \multicolumn{3}{|c|}{ Less than Four Years of College (Detail) } & \multirow{3}{*}{$\begin{array}{c}\text { Noncoll.-Coll } \\
\text { Difference } \\
\text { Average } \\
\text { (7) }\end{array}$} & \multirow{3}{*}{$\begin{array}{c}\text { Noncoll.-Coll } \\
\text { Difference } \\
\text { Adjusted } \\
(8)\end{array}$} \\
\hline & & & & & Less Than & High School & Some College & & \\
\hline & & & & & $\begin{array}{c}\text { High School } \\
\text { (4) }\end{array}$ & $\begin{array}{c}\text { Graduates } \\
\text { (5) }\end{array}$ & & & \\
\hline \multirow[t]{2}{*}{ May88 } & 16084 & 0.827 & 0.921 & 0.803 & 0.705 & 0.815 & 0.842 & -0.118 & -0.099 \\
\hline & & $(0.002)$ & $(0.003)$ & $(0.003)$ & $(0.008)$ & $(0.003)$ & $(0.004)$ & $(0.005)$ & $(0.007)$ \\
\hline \multirow[t]{2}{*}{ Apr93 } & 15731 & 0.805 & 0.910 & 0.775 & 0.595 & 0.788 & 0.820 & -0.135 & -0.121 \\
\hline & & $(0.002)$ & $(0.003)$ & $(0.003)$ & $(0.009)$ & $(0.004)$ & $(0.004)$ & $(0.005)$ & $(0.008)$ \\
\hline \multirow[t]{2}{*}{ Feb95 } & 33693 & 0.826 & 0.917 & 0.797 & 0.650 & 0.806 & 0.833 & -0.119 & -0.108 \\
\hline & & $(0.003)$ & $(0.004)$ & $(0.004)$ & $(0.013)$ & $(0.005)$ & $(0.005)$ & $(0.007)$ & $(0.005)$ \\
\hline \multirow[t]{2}{*}{ Feb97 } & 30003 & 0.835 & 0.917 & 0.808 & 0.664 & 0.810 & 0.851 & -0.108 & -0.098 \\
\hline & & $(0.003)$ & $(0.004)$ & $(0.004)$ & $(0.013)$ & $(0.005)$ & $(0.005)$ & $(0.007)$ & $(0.005)$ \\
\hline All & 95511 & $\begin{array}{c}0.821 \\
(0.001)\end{array}$ & $\begin{array}{c}0.916 \\
(0.002)\end{array}$ & $\begin{array}{c}0.794 \\
(0.001)\end{array}$ & $\begin{array}{c}0.658 \\
(0.005)\end{array}$ & $\begin{array}{c}0.804 \\
(0.002)\end{array}$ & $\begin{array}{c}0.834 \\
(0.002)\end{array}$ & $\begin{array}{l}-0.122 \\
(0.003)\end{array}$ & $\begin{array}{l}-0.108 \\
(0.003)\end{array}$ \\
\hline
\end{tabular}

Note: The numbers in parentheses are standard errors. The numbers in columns 1-6 are the fraction of workers in each group who are in a firm that offers health insurance to at least some workers in the firm based on weighted tabulations of data from the relevant supplements to the CPS. The average difference in column 7 is computed as the difference between the health insurance offering rate for workers with less than four year of college (column 3 ) and the offering rate for all workers with four years of college or more (column 2). The adjusted differences reported in column 8 are the coefficients on a less-than-four-years-of-college dummy variable from separate OLS regressions for each year of the health insurance offering indicator on the less-than-college dummy variable and controls for age, education, sex, race, marital status, and the interaction of sex and marital status. The regression adjustment for the "all" sample includes survey dummy variables as well. All counts are weighted by the CPS supplement weights. The sample includes all private sector workers ages $20-64$ who are not self-employed. 
Table A2

Fraction Eligible for Health Insurance Coverage Conditional on Employer Offering by Year and Educational Attainment Private Sector Workers Ages 20-64 All Job Types (Core and Peripheral)

\begin{tabular}{|c|c|c|c|c|c|c|c|c|c|}
\hline \multirow[t]{2}{*}{ Year } & \multirow{2}{*}{$\begin{array}{c}\text { Sample } \\
\text { Size }\end{array}$} & \multirow{2}{*}{$\begin{array}{c}\text { All Jobs } \\
\text { Average } \\
\text { (1) }\end{array}$} & \multirow{2}{*}{$\begin{array}{l}\text { College } \\
\text { Graduates } \\
(2)\end{array}$} & \multirow{2}{*}{$\begin{array}{c}\text { Less than } 4 \\
\text { Years of } \\
\text { College } \\
\text { (3) }\end{array}$} & \multicolumn{3}{|c|}{ Less than Four Years of College (Detail) } & \multirow{2}{*}{$\begin{array}{c}\text { Noncoll.-Coll } \\
\text { Difference } \\
\text { Average } \\
\text { (7) }\end{array}$} & \multirow{2}{*}{$\begin{array}{c}\text { Noncoll.-Coll } \\
\text { Difference } \\
\text { Adjusted } \\
\text { (8) }\end{array}$} \\
\hline & & & & & $\begin{array}{c}\text { Less Than } \\
\text { High School } \\
\text { (4) }\end{array}$ & $\begin{array}{c}\text { High School } \\
\text { Graduates } \\
\text { (5) }\end{array}$ & $\begin{array}{c}\text { Some College } \\
\text { (6) }\end{array}$ & & \\
\hline May88 & 16084 & 0.943 & 0.971 & 0.935 & 0.938 & 0.938 & 0.927 & -0.036 & -0.027 \\
\hline & & $(0.002)$ & $(0.003)$ & $(0.002)$ & $(0.005)$ & $(0.003)$ & $(0.004)$ & $(0.004)$ & $(0.005)$ \\
\hline Apr93 & 15731 & 0.917 & 0.942 & 0.909 & 0.911 & 0.917 & 0.900 & -0.033 & -0.020 \\
\hline & & $(0.002)$ & $(0.003)$ & $(0.002)$ & $(0.006)$ & $(0.003)$ & $(0.003)$ & $(0.004)$ & $(0.006)$ \\
\hline Feb95 & 33584 & 0.912 & 0.940 & 0.901 & 0.903 & 0.908 & 0.894 & -0.039 & -0.027 \\
\hline & & $(0.002)$ & $(0.004)$ & $(0.003)$ & $(0.009)$ & $(0.004)$ & $(0.004)$ & $(0.005)$ & $(0.004)$ \\
\hline Feb97 & 29971 & 0.912 & 0.946 & 0.900 & 0.902 & 0.909 & 0.891 & -0.046 & -0.032 \\
\hline & & $(0.002)$ & $(0.003)$ & $(0.003)$ & $(0.009)$ & $(0.004)$ & $(0.004)$ & $(0.005)$ & $(0.004)$ \\
\hline All & 95316 & 0.924 & 0.951 & 0.915 & 0.920 & 0.922 & 0.904 & -0.036 & -0.026 \\
\hline
\end{tabular}

Note: The numbers in parentheses are standard errors. The numbers in columns 1-6 are the fraction of workers in each group who are eligible for health insurance, conditional on being in a firm that offers it, based on weighted tabulations of data from the relevant supplements to the CPS. The average difference in column 7 is computed as the difference between the health insurance eligibility rate for workers with less than four years of college (column 3 ) and the coverage rate for all workers with four years of college or more (column 2). The adjusted differences reported in column 8 are the coefficients on a less-than-four-yearsof-college dummy variable from separate OLS regressions for each year of the health insurance eligibility indicator on the less-than-college dummy variable and controls for age, education, sex, race, marital status, and the interaction of sex and marital status. The regression adjustment for the "all" sample includes survey dummy variables as well. All counts are weighted by the CPS supplement weights. The sample includes all private sector workers ages $20-64$ who are not selfemployed. 
Table A3

Fraction Covered by Employer-Provided Health Insurance Conditional on Eligibility (Takeup Rate)

by Year and Educational Attainment

Private Sector Workers Ages 20-64

All Job Types (Core and Peripheral)

\begin{tabular}{|c|c|c|c|c|c|c|c|c|c|}
\hline \multirow[t]{2}{*}{ Year } & \multirow{2}{*}{$\begin{array}{l}\text { Sample } \\
\text { Size }\end{array}$} & \multirow{2}{*}{$\begin{array}{c}\text { All Jobs } \\
\text { Average } \\
\text { (1) }\end{array}$} & \multirow{2}{*}{$\begin{array}{c}\text { College } \\
\text { Graduates } \\
\text { (2) }\end{array}$} & \multirow{2}{*}{$\begin{array}{l}\text { Less than } 4 \\
\text { Years of } \\
\text { College } \\
(3)\end{array}$} & \multicolumn{3}{|c|}{ Less than Four Years of College (Detail) } & \multirow{2}{*}{$\begin{array}{c}\text { Noncoll.-Coll } \\
\text { Difference } \\
\text { Average } \\
(7) \\
\end{array}$} & \multirow{2}{*}{$\begin{array}{l}\text { Noncoll.-Coll } \\
\text { Difference } \\
\text { Adjusted } \\
(8) \\
\end{array}$} \\
\hline & & & & & $\begin{array}{c}\text { Less Than } \\
\text { High School } \\
\text { (4) }\end{array}$ & $\begin{array}{c}\text { High School } \\
\text { Graduates } \\
(5)\end{array}$ & $\begin{array}{c}\text { Some College } \\
\text { (6) }\end{array}$ & & \\
\hline May88 & 12548 & $\begin{array}{c}0.886 \\
(0002)\end{array}$ & $\begin{array}{c}0.916 \\
(0.004)\end{array}$ & $\begin{array}{c}0.877 \\
(0.003)\end{array}$ & 0.875 & 0.879 & 0.872 & -0.040 & -0.025 \\
\hline Apr93 & 11622 & $\begin{array}{c}0.876 \\
(0.002)\end{array}$ & $\begin{array}{c}0.904 \\
(0.004)\end{array}$ & $\begin{array}{c}0.867 \\
(0.003)\end{array}$ & $\begin{array}{c}(0.00 /) \\
0.871 \\
(0.009)\end{array}$ & $\begin{array}{c}(0.003) \\
0.868 \\
(0.004)\end{array}$ & $\begin{array}{c}(0.005) \\
0.864 \\
(0.004)\end{array}$ & $\begin{array}{l}(0.005) \\
-0.037 \\
(0.005)\end{array}$ & $\begin{array}{l}(0.00 /) \\
-0.024 \\
(0.007)\end{array}$ \\
\hline Feb95 & 25340 & $\begin{array}{c}0.855 \\
(0.003)\end{array}$ & $\begin{array}{c}0.886 \\
(0.005)\end{array}$ & $\begin{array}{c}0.843 \\
(0.004)\end{array}$ & $\begin{array}{c}0.830 \\
(0.012)\end{array}$ & $\begin{array}{c}0.848 \\
(0.005)\end{array}$ & $\begin{array}{c}0.841 \\
(0.006)\end{array}$ & $\begin{array}{l}-0.043 \\
(0.007)\end{array}$ & $\begin{array}{l}-0.035 \\
(0.005)\end{array}$ \\
\hline Feb97 & 22801 & $\begin{array}{c}0.850 \\
(0.003) \\
\end{array}$ & $\begin{array}{c}0.879 \\
(0.005) \\
\end{array}$ & $\begin{array}{c}0.839 \\
(0.004) \\
\end{array}$ & $\begin{array}{c}0.842 \\
(0.012) \\
\end{array}$ & $\begin{array}{c}0.839 \\
(0.005) \\
\end{array}$ & $\begin{array}{c}0.838 \\
(0.006) \\
\end{array}$ & $\begin{array}{l}-0.041 \\
(0.007)\end{array}$ & $\begin{array}{l}-0.035 \\
(0.005)\end{array}$ \\
\hline All & 72311 & $\begin{array}{c}0.871 \\
(0.001)\end{array}$ & $\begin{array}{c}0.900 \\
(0.002)\end{array}$ & $\begin{array}{c}0.862 \\
(0.001)\end{array}$ & $\begin{array}{c}0.863 \\
(0.005)\end{array}$ & $\begin{array}{c}0.865 \\
(0.002)\end{array}$ & $\begin{array}{c}0.609 \\
(0.002)\end{array}$ & $\begin{array}{l}-0.038 \\
(0.003)\end{array}$ & $\begin{array}{l}-0.028 \\
(0.003)\end{array}$ \\
\hline
\end{tabular}

Note: The numbers in parentheses are standard errors. The numbers in columns 1-6 are the fraction of workers in each group who are enrolled in their employer's health insurance plan, conditional on being eligible for it, based on weighted tabulations of data from the relevant supplements to the CPS. The average difference in column 7 is computed as the difference between the enrollment rate for workers with education less than four years of college (column 3 ) and the enrollment rate for workers with four years of college or more (column 2). The adjusted differences reported in column 8 are the coefficients on a lessthan-four-years-of-college dummy variable from separate OLS regressions for each year of the health insurance takeup indicator on the less-than-four-years-ofcollege dummy variable and controls for age, education, sex, race, marital status, and the interaction of sex and marital status. The regression adjustment for the "all" sample includes survey dummy variables as well. All counts are weighted by the CPS supplement weights. The sample includes all private sector workers ages 20-64 who are not self-employed. 
Table A4

Fraction of Workers with Coverage as a Dependent on a Spouse's Employer-Sponsored Health Insurance Policy (Spousal Coverage Rate)

by Year and Educational Attainment

Private Sector Workers Ages 20-64

All Job Types (Core and Peripheral)

\begin{tabular}{|c|c|c|c|c|c|c|c|c|c|}
\hline \multirow[t]{2}{*}{ Year } & \multirow{2}{*}{$\begin{array}{c}\text { Sample } \\
\text { Size }\end{array}$} & \multirow{2}{*}{$\begin{array}{c}\text { All Jobs } \\
\text { Average } \\
(1)\end{array}$} & \multirow{2}{*}{$\begin{array}{l}\text { College } \\
\text { Graduates } \\
\text { (2) }\end{array}$} & \multirow{2}{*}{$\begin{array}{c}\text { Less than } 4 \\
\text { Years of } \\
\text { College } \\
(3)\end{array}$} & \multicolumn{3}{|c|}{ Less than Four Years of College (Detail) } & \multirow{2}{*}{$\begin{array}{c}\text { Noncoll.-Coll } \\
\text { Difference } \\
\text { Average } \\
(7)\end{array}$} & \multirow{2}{*}{$\begin{array}{c}\text { Noncoll.-Coll } \\
\text { Difference } \\
\text { Adjusted } \\
(8)\end{array}$} \\
\hline & & & & & $\begin{array}{c}\text { Less Than } \\
\text { High School } \\
(4)\end{array}$ & $\begin{array}{c}\text { High School } \\
\text { Graduates } \\
(5)\end{array}$ & $\begin{array}{c}\text { Some College } \\
(6)\end{array}$ & & \\
\hline May88 & 14737 & $\begin{array}{c}0.094 \\
(0.002)\end{array}$ & $\begin{array}{c}0.082 \\
(0.004)\end{array}$ & $\begin{array}{c}0.097 \\
(0.002)\end{array}$ & $\begin{array}{c}0.068 \\
(0.004)\end{array}$ & $\begin{array}{c}0.106 \\
(0.003)\end{array}$ & $\begin{array}{c}0.097 \\
(0.004)\end{array}$ & $\begin{array}{c}0.014 \\
(0.004)\end{array}$ & $\begin{array}{c}0.013 \\
(0.006)\end{array}$ \\
\hline Apr93 & 14557 & $\begin{array}{c}0.107 \\
(0.002)\end{array}$ & $\begin{array}{c}0.108 \\
(0.004)\end{array}$ & $\begin{array}{c}0.107 \\
(0.002)\end{array}$ & $\begin{array}{c}0.063 \\
(0.005)\end{array}$ & $\begin{array}{c}0.109 \\
(0.003)\end{array}$ & $\begin{array}{c}0.121 \\
(0.003)\end{array}$ & $\begin{array}{l}-0.001 \\
(0.004)\end{array}$ & $\begin{array}{c}0.001 \\
(0.006)\end{array}$ \\
\hline Feb95 & 32506 & $\begin{array}{c}0.107 \\
(0.002)\end{array}$ & $\begin{array}{c}0.111 \\
(0.005)\end{array}$ & $\begin{array}{c}0.105 \\
(0.003)\end{array}$ & $\begin{array}{c}0.061 \\
(0.007)\end{array}$ & $\begin{array}{c}0.109 \\
(0.004)\end{array}$ & $\begin{array}{c}0.116 \\
(0.004)\end{array}$ & $\begin{array}{l}-0.005 \\
(0.006)\end{array}$ & $\begin{array}{l}-0.001 \\
(0.004)\end{array}$ \\
\hline Feb97 & 28921 & $\begin{array}{c}0.109 \\
(0.002) \\
\end{array}$ & $\begin{array}{c}0.113 \\
(0.005) \\
\end{array}$ & $\begin{array}{c}0.108 \\
(0.003) \\
\end{array}$ & $\begin{array}{c}0.059 \\
(0.007) \\
\end{array}$ & $\begin{array}{c}0.114 \\
(0.004) \\
\end{array}$ & $\begin{array}{c}0.115 \\
(0.004) \\
\end{array}$ & $\begin{array}{l}-0.006 \\
(0.006) \\
\end{array}$ & $\begin{array}{l}-0.001 \\
(0.004) \\
\end{array}$ \\
\hline All & 90721 & $\begin{array}{c}0.103 \\
(0.001)\end{array}$ & $\begin{array}{c}0.102 \\
(0.002)\end{array}$ & $\begin{array}{c}0.104 \\
(0.001)\end{array}$ & $\begin{array}{c}0.064 \\
(0.003)\end{array}$ & $\begin{array}{c}0.108 \\
(0.002)\end{array}$ & $\begin{array}{c}0.113 \\
(0.002)\end{array}$ & $\begin{array}{c}0.002 \\
(0.002)\end{array}$ & $\begin{array}{c}0.004 \\
(0.002)\end{array}$ \\
\hline
\end{tabular}

Note: The numbers in parentheses are standard errors. The numbers in columns 1-6 are the fraction of workers in each group with employer-sponsored health insurance coverage as a dependent on a spouse's policy based on weighted tabulations of data from the relevant supplements to the CPS. The average difference in column 7 is computed as the difference between the spousal health insurance coverage rate for workers with education less than four years of college (column 3 ) and the spousal coverage rate for workers with four years of college or more (column 2). The adjusted differences reported in column 8 are the coefficients on a less-than-four-year-of-college dummy variable from separate OLS regressions for each year of the spousal health insurance coverage indicator on the less-thanfour-years-of-college dummy variable and controls for age, education, sex, and race. The regression adjustment for the "all" sample includes survey dummy variables as well. All counts are weighted by the CPS supplement weights. The sample includes all private sector workers ages $20-64$ who are not self-employed. 
Table A5

Fraction of Workers with any Employer-Sponsored Health Insurance Coverage by Year and Educational Attainment Private Sector Workers Ages 20-64 All Job Types (Core and Peripheral)

\begin{tabular}{|c|c|c|c|c|c|c|c|c|c|}
\hline \multirow[t]{2}{*}{ Year } & \multirow{2}{*}{$\begin{array}{c}\text { Sample } \\
\text { Size }\end{array}$} & \multirow{2}{*}{$\begin{array}{c}\text { All Jobs } \\
\text { Average } \\
\text { (1) }\end{array}$} & \multirow{2}{*}{$\begin{array}{l}\text { College } \\
\text { Graduates } \\
(2)\end{array}$} & \multirow{2}{*}{$\begin{array}{c}\text { Less than } 4 \\
\text { Years of } \\
\text { College } \\
(3)\end{array}$} & \multicolumn{3}{|c|}{ Less than Four Years of College (Detail) } & \multirow{2}{*}{$\begin{array}{c}\text { Noncoll.-Coll } \\
\text { Difference } \\
\text { Average } \\
\text { (7) }\end{array}$} & \multirow{2}{*}{$\begin{array}{c}\text { Noncoll.-Coll } \\
\text { Difference } \\
\text { Adjusted } \\
(8)\end{array}$} \\
\hline & & & & & $\begin{array}{c}\text { Less Than } \\
\text { High School } \\
(4)\end{array}$ & $\begin{array}{c}\text { High School } \\
\text { Graduates } \\
\text { (5) }\end{array}$ & $\begin{array}{c}\text { Some College } \\
(6)\end{array}$ & & \\
\hline \multirow[t]{2}{*}{ May88 } & 14737 & 0.784 & 0.906 & 0.753 & 0.644 & 0.777 & 0.776 & -0.154 & -0.125 \\
\hline & & $(0.003)$ & $(0.004)$ & $(0.003)$ & $(0.008)$ & $(0.004)$ & $(0.005)$ & $(0.006)$ & $(0.008)$ \\
\hline \multirow[t]{2}{*}{ Apr93 } & 14557 & 0.754 & 0.882 & 0.718 & 0.537 & 0.739 & 0.756 & -0.164 & -0.137 \\
\hline & & $(0.002)$ & $(0.004)$ & $(0.003)$ & $(0.008)$ & $(0.004)$ & $(0.004)$ & $(0.006)$ & $(0.008)$ \\
\hline \multirow[t]{2}{*}{ Feb95 } & 32506 & 0.748 & 0.873 & 0.710 & 0.544 & 0.728 & 0.740 & -0.163 & -0.138 \\
\hline & & $(0.003)$ & $(0.005)$ & $(0.004)$ & $(0.014)$ & $(0.006)$ & $(0.006)$ & $(0.008)$ & $(0.005)$ \\
\hline \multirow[t]{2}{*}{ Feb97 } & 28921 & 0.756 & 0.876 & 0.718 & 0.563 & 0.731 & 0.750 & -0.158 & -0.132 \\
\hline & & $(0.003)$ & $(0.005)$ & $(0.004)$ & $(0.013)$ & $(0.006)$ & $(0.006)$ & $(0.008)$ & $(0.006)$ \\
\hline All & 90721 & $\begin{array}{c}0.763 \\
(0.001)\end{array}$ & $\begin{array}{c}0.886 \\
(0.002)\end{array}$ & $\begin{array}{c}0.728 \\
(0.002)\end{array}$ & $\begin{array}{c}0.585 \\
(0.005)\end{array}$ & $\begin{array}{c}0.749 \\
(0.002)\end{array}$ & $\begin{array}{c}0.756 \\
(0.003)\end{array}$ & $\begin{array}{l}-0.158 \\
(0.003)\end{array}$ & $\begin{array}{l}-0.133 \\
(0.003)\end{array}$ \\
\hline
\end{tabular}

Note: The numbers in parentheses are standard errors. The numbers in columns 1-6 are the fraction of workers in each group with employer-sponsored health insurance coverage as a dependent on a spouse's policy based on weighted tabulations of data from the relevant supplements to the CPS. The average difference in column 7 is computed as the difference between the rate of employer-sponsored health insurance coverage from any source for workers with education less than four years of college (column 3) and the coverage rate for workers with four years of college or more (column 2). The adjusted differences reported in column 8 are the coefficients on a less-than-four-years-of-college dummy variable from separate OLS regressions for each year of the health insurance coverage indicator on the less-than-four-years-of-college dummy variable and controls for age, education, sex, and race. The regression adjustment for the "all" sample includes survey dummy variables as well. All counts are weighted by the CPS supplement weights. The sample includes all private sector workers ages $20-64$ who are not self-employed. 
Table A6

Employment Distribution across Educational Attainment Categories

$$
\text { By Year }
$$

Private Sector Workers Ages 20-64

All Job Types (Core and Peripheral)

\begin{tabular}{l|r|rccc|c} 
Year & $\mathrm{N}$ & $\begin{array}{c}\text { Less Than } \\
\text { High } \\
\text { School } \\
(1)\end{array}$ & $\begin{array}{c}\text { High } \\
\text { School } \\
\text { Graduates } \\
(2)\end{array}$ & $\begin{array}{c}\text { Less than } \\
\text { 4 Years of } \\
\text { College } \\
(3)\end{array}$ & $\begin{array}{c}\text { College } \\
\text { Graduates }\end{array}$ & Total \\
\hline May79 & 15949 & 0.208 & 0.445 & 0.197 & 0.151 & 1.000 \\
Jan83 & 9763 & 0.171 & 0.423 & 0.215 & 0.191 & 1.000 \\
May83 & 17142 & 0.169 & 0.432 & 0.206 & 0.193 & 1.000 \\
Jan87 & 10382 & 0.158 & 0.435 & 0.220 & 0.187 & 1.000 \\
May88 & 16693 & 0.145 & 0.435 & 0.219 & 0.201 & 1.000 \\
Jan91 & 10034 & 0.127 & 0.419 & 0.236 & 0.218 & 1.000 \\
Apr93 & 16253 & 0.115 & 0.367 & 0.298 & 0.220 & 1.000 \\
Feb95 & 35140 & 0.098 & 0.353 & 0.314 & 0.235 & 1.000 \\
Feb96 & 28041 & 0.112 & 0.354 & 0.307 & 0.228 & 1.000 \\
Feb97 & 31288 & 0.096 & 0.360 & 0.305 & 0.239 & 1.000 \\
\hline All & 190685 & 0.137 & 0.400 & 0.254 & 0.208 & 1.000
\end{tabular}

Note: The numbers in columns 1-4 are the fraction of workers in each group based on weighted tabulations of data from the relevant supplements to the CPS. All counts are weighted by the CPS final sampling weights. Self-employed workers and workers with missing data on tenure or hours of work are not included in the analysis. Incorporated self-employed workers are included in May 1979. The sample includes workers aged 20-64 only. 
Table A7

Fraction Covered by Health Insurance Provided by Their Employer by Year and Educational Attainment Private Sector Workers Ages 20-64

Core Jobs Only

\begin{tabular}{|c|c|c|c|c|c|c|c|c|c|}
\hline \multirow{2}{*}{ Year } & \multirow{2}{*}{\begin{tabular}{|} 
Sample \\
Size
\end{tabular}} & \multirow{2}{*}{$\begin{array}{c}\text { All Jobs } \\
\text { Average } \\
\text { (1) }\end{array}$} & \multirow{2}{*}{$\begin{array}{c}\text { College } \\
\text { Graduates } \\
\text { (2) }\end{array}$} & \multirow{2}{*}{$\begin{array}{c}\text { Less than } 4 \\
\text { Years of } \\
\text { College } \\
\text { (3) }\end{array}$} & \multicolumn{3}{|c|}{ Less than Four Years of College (Detail) } & \multirow{2}{*}{$\begin{array}{c}\text { Noncoll.-Coll } \\
\text { Difference } \\
\text { Average } \\
(7)\end{array}$} & \multirow{2}{*}{$\begin{array}{l}\text { Noncoll.-Coll } \\
\text { Difference } \\
\text { Adjusted } \\
\text { (8) }\end{array}$} \\
\hline & & & & & $\begin{array}{c}\text { Less Than } \\
\text { High School } \\
(4)\end{array}$ & $\begin{array}{l}\text { High School } \\
\text { Graduates } \\
(5)\end{array}$ & $\begin{array}{c}\text { Some College } \\
\text { (6) }\end{array}$ & & \\
\hline May79 & 11059 & $\begin{array}{c}0.828 \\
0003\end{array}$ & $\begin{array}{c}0.896 \\
0\end{array}$ & 0.816 & 0.773 & 0.827 & 0.839 & -0.079 & -0.056 \\
\hline May83 & 12129 & $\begin{array}{c}(0.003) \\
0.835 \\
(0.003)\end{array}$ & $\begin{array}{c}(0.009 \\
0.899 \\
(0.005)\end{array}$ & $\begin{array}{c}(0.004) \\
0.819 \\
(0.004)\end{array}$ & $\begin{array}{c}(0.008) \\
0.776 \\
(0.009)\end{array}$ & $\begin{array}{c}(0.005) \\
0.829 \\
(0.005)\end{array}$ & $\begin{array}{c}(0.007) \\
0.832 \\
(0.007)\end{array}$ & $\begin{array}{l}(0.008) \\
-0.080 \\
(0.008)\end{array}$ & $\begin{array}{l}(0.010) \\
-0.063 \\
(0.008)\end{array}$ \\
\hline May88 & 11353 & $\begin{array}{c}0.813 \\
(0.003)\end{array}$ & $\begin{array}{c}0.902 \\
(0.005)\end{array}$ & $\begin{array}{c}0.788 \\
(0.003)\end{array}$ & $\begin{array}{c}0.712 \\
(0.009)\end{array}$ & $\begin{array}{c}0.797 \\
(0.005)\end{array}$ & $\begin{array}{c}0.821 \\
(0.006)\end{array}$ & $\begin{array}{l}-0.113 \\
(0.007)\end{array}$ & $\begin{array}{l}-0.095 \\
(0.009)\end{array}$ \\
\hline Apr93 & 11358 & $\begin{array}{c}0.770 \\
(0.003)\end{array}$ & $\begin{array}{c}0.858 \\
(0.005)\end{array}$ & $\begin{array}{c}0.743 \\
(0.003)\end{array}$ & $\begin{array}{c}0.598 \\
(0.011)\end{array}$ & $\begin{array}{c}0.752 \\
(0.005)\end{array}$ & $\begin{array}{c}0.781 \\
(0.005)\end{array}$ & $\begin{array}{l}-0.115 \\
(0.007)\end{array}$ & $\begin{array}{l}-0.103 \\
(0.009)\end{array}$ \\
\hline Feb95 & 23774 & $\begin{array}{c}0.770 \\
(0.004)\end{array}$ & $\begin{array}{c}0.852 \\
(0.006)\end{array}$ & $\begin{array}{c}0.743 \\
(0.005)\end{array}$ & $\begin{array}{c}0.614 \\
(0.016)\end{array}$ & $\begin{array}{c}0.739 \\
(0.007)\end{array}$ & $\begin{array}{c}0.790 \\
(0.017)\end{array}$ & $\begin{array}{l}-0.109 \\
(0.009)\end{array}$ & $\begin{array}{l}-0.099 \\
(0.006)\end{array}$ \\
\hline Feb97 & 21242 & $\begin{array}{c}0.770 \\
(0.004)\end{array}$ & $\begin{array}{c}0.851 \\
(0.006)\end{array}$ & $\begin{array}{c}0.743 \\
(0.005)\end{array}$ & $\begin{array}{c}0.614 \\
(0.016)\end{array}$ & $\begin{array}{c}0.741 \\
(0.007)\end{array}$ & $\begin{array}{c}0.786 \\
(0.007)\end{array}$ & $\begin{array}{l}-0.108 \\
(0.009)\end{array}$ & $\begin{array}{l}-0.100 \\
(0.007)\end{array}$ \\
\hline All & 90915 & $\begin{array}{c}0.801 \\
(0.001)\end{array}$ & $\begin{array}{c}0.877 \\
(0.002)\end{array}$ & $\begin{array}{c}0.780 \\
(0.002)\end{array}$ & $\begin{array}{c}0.710 \\
(0.004)\end{array}$ & $\begin{array}{c}0.788 \\
(0.002)\end{array}$ & $\begin{array}{c}0.805 \\
(0.003)\end{array}$ & $\begin{array}{l}-0.097 \\
(0.003)\end{array}$ & $\begin{array}{l}-0.087 \\
(0.003)\end{array}$ \\
\hline
\end{tabular}

Note: The numbers in parentheses are standard errors. The numbers in columns 1-6 are the fraction of workers in each group reporting that they are covered by their own employer-provided health insurance based on weighted tabulations of data from the relevant supplements to the CPS. The average difference in column 7 is computed as the difference between the health insurance coverage rate for workers with less than four years of college (column 3 ) and the coverage rate for all workers with four years of college or more (column 2). The adjusted differences reported in column 8 are the coefficients on a less-than-four-years-of-college dummy variable from separate OLS regressions for each year of the health insurance coverage indicator on the less-than-college dummy variable and controls for age, education, sex, race, marital status, and the interaction of sex and marital status. The regression adjustment for the "all" sample includes survey dummy variables as well. All counts are weighted by the CPS supplement weights. The sample includes all private sector workers ages 20-64 who are not self-employed. 
Table A8

Fraction Whose Employers Offer Health Insurance Coverage to at least Some Employees by Year and Educational Attainment

Private Sector Workers Ages 20-64

Core Jobs Only

\begin{tabular}{|c|c|c|c|c|c|c|c|c|c|}
\hline \multirow[t]{2}{*}{ Year } & \multirow{2}{*}{$\begin{array}{c}\text { Sample } \\
\text { Size }\end{array}$} & \multirow{2}{*}{$\begin{array}{c}\text { All Jobs } \\
\text { Average } \\
\text { (1) }\end{array}$} & \multirow{2}{*}{$\begin{array}{l}\text { College } \\
\text { Graduates } \\
\text { (2) }\end{array}$} & \multirow{2}{*}{$\begin{array}{c}\text { Less than } 4 \\
\text { Years of } \\
\text { College } \\
(3)\end{array}$} & \multicolumn{3}{|c|}{ Less than Four Years of College (Detail) } & \multirow{2}{*}{$\begin{array}{c}\text { Noncoll.-Coll } \\
\text { Difference } \\
\text { Average } \\
(7)\end{array}$} & \multirow{2}{*}{$\begin{array}{l}\text { Noncoll.-Coll } \\
\text { Difference } \\
\text { Adjusted } \\
\text { (8) }\end{array}$} \\
\hline & & & & & $\begin{array}{c}\text { Less Than } \\
\text { High School } \\
\text { (4) }\end{array}$ & $\begin{array}{l}\text { High School } \\
\text { Graduates } \\
\text { (5) }\end{array}$ & $\begin{array}{c}\text { Some College } \\
\text { (6) }\end{array}$ & & \\
\hline May88 & 11379 & $\begin{array}{c}0.888 \\
(0.002)\end{array}$ & $\begin{array}{c}0.953 \\
(0.003)\end{array}$ & $\begin{array}{c}0.869 \\
(0.003)\end{array}$ & $\begin{array}{c}0.790 \\
(0.009)\end{array}$ & $\begin{array}{c}0.876 \\
(0.004)\end{array}$ & $\begin{array}{c}0.908 \\
(0.004)\end{array}$ & $\begin{array}{l}-0.084 \\
(0.005)\end{array}$ & $\begin{array}{l}-0.074 \\
(0.007)\end{array}$ \\
\hline Apr93 & 11367 & $\begin{array}{c}0.870 \\
(0.002)\end{array}$ & $\begin{array}{c}0.949 \\
(0.003)\end{array}$ & $\begin{array}{c}0.846 \\
(0.003)\end{array}$ & $\begin{array}{c}0.684 \\
(0.010)\end{array}$ & $\begin{array}{c}0.858 \\
(0.004)\end{array}$ & $\begin{array}{c}0.885 \\
(0.004)\end{array}$ & $\begin{array}{l}-0.103 \\
(0.005)\end{array}$ & $\begin{array}{l}-0.097 \\
(0.007)\end{array}$ \\
\hline Feb95 & 23774 & $\begin{array}{c}0.883 \\
(0.003)\end{array}$ & $\begin{array}{c}0.948 \\
(0.004)\end{array}$ & $\begin{array}{c}0.862 \\
(0.004)\end{array}$ & $\begin{array}{c}0.724 \\
(0.014)\end{array}$ & $\begin{array}{c}0.861 \\
(0.005)\end{array}$ & $\begin{array}{c}0.906 \\
(0.005)\end{array}$ & $\begin{array}{l}-0.086 \\
(0.007)\end{array}$ & $\begin{array}{l}-0.080 \\
(0.005)\end{array}$ \\
\hline Feb97 & 21242 & $\begin{array}{c}0.889 \\
(0.003) \\
\end{array}$ & $\begin{array}{c}0.951 \\
(0.004)\end{array}$ & $\begin{array}{c}0.868 \\
(0.004) \\
\end{array}$ & $\begin{array}{c}0.729 \\
(0.014)\end{array}$ & $\begin{array}{c}0.868 \\
(0.005)\end{array}$ & $\begin{array}{c}0.913 \\
(0.005)\end{array}$ & $\begin{array}{l}-0.083 \\
(0.007)\end{array}$ & $\begin{array}{l}-0.078 \\
(0.005)\end{array}$ \\
\hline All & 67762 & $\begin{array}{c}0.881 \\
(0.001)\end{array}$ & $\begin{array}{c}0.950 \\
(0.002)\end{array}$ & $\begin{array}{c}0.860 \\
(0.002)\end{array}$ & $\begin{array}{c}0.739 \\
(0.005)\end{array}$ & $\begin{array}{c}0.866 \\
(0.002)\end{array}$ & $\begin{array}{c}0.900 \\
(0.002)\end{array}$ & $\begin{array}{l}-0.090 \\
(0.003)\end{array}$ & $\begin{array}{l}-0.084 \\
(0.003)\end{array}$ \\
\hline
\end{tabular}

Note: The numbers in parentheses are standard errors. The numbers in columns 1-6 are the fraction of workers in each group who are in a firm that offers health insurance to at least some workers in the firm based on weighted tabulations of data from the relevant supplements to the CPS. The average difference in column 7 is computed as the difference between the health insurance offering rate for workers with less than four year of college (column 3) and the offering rate for all workers with four years of college or more (column 2). The adjusted differences reported in column 8 are the coefficients on a less-than-four-years-of-college dummy variable from separate OLS regressions for each year of the health insurance offering indicator on the less-than-college dummy variable and controls for age, education, sex, race, marital status, and the interaction of sex and marital status. The regression adjustment for the "all" sample includes survey dummy variables as well. All counts are weighted by the CPS supplement weights. The sample includes all private sector workers ages 20-64 who are not self-employed. 
Table A9

Fraction Eligible for Health Insurance Coverage Conditional on Employer Offering by Year and Educational Attainment

Private Sector Workers Ages 20-64

Core Jobs Only

\begin{tabular}{|c|c|c|c|c|c|c|c|c|c|}
\hline \multirow[t]{2}{*}{ Year } & \multirow{2}{*}{$\begin{array}{l}\text { Sample } \\
\text { Size }\end{array}$} & \multirow{2}{*}{$\begin{array}{c}\text { All Jobs } \\
\text { Average } \\
\text { (1) }\end{array}$} & \multirow{2}{*}{$\begin{array}{l}\text { College } \\
\text { Graduates } \\
\text { (2) }\end{array}$} & \multirow{2}{*}{$\begin{array}{l}\text { Less than } 4 \\
\text { Years of } \\
\text { College } \\
\text { (3) }\end{array}$} & \multicolumn{3}{|c|}{ Less than Four Years of College (Detail) } & \multirow{2}{*}{$\begin{array}{c}\text { Noncoll.-Coll } \\
\text { Difference } \\
\text { Average } \\
\text { (7) }\end{array}$} & \multirow{2}{*}{$\begin{array}{l}\text { Noncoll.-Coll } \\
\text { Difference } \\
\text { Adjusted } \\
\text { (8) }\end{array}$} \\
\hline & & & & & $\begin{array}{c}\text { Less Than } \\
\text { High School } \\
\text { (4) }\end{array}$ & $\begin{array}{c}\text { High School } \\
\text { Graduates }\end{array}$ & $\begin{array}{c}\text { Some College } \\
\text { (6) }\end{array}$ & & \\
\hline May88 & 11379 & 0.990 & 0.995 & 0.988 & 0.987 & 0.991 & 0.982 & -0.007 & -0.006 \\
\hline & & $(0.001)$ & $(0.002)$ & $(0.001)$ & $(0.003)$ & $(0.002)$ & $(0.002)$ & $(0.002)$ & $(0.002)$ \\
\hline Apr93 & 11367 & $\begin{array}{c}0.976 \\
(0.001)\end{array}$ & $\begin{array}{c}0.982 \\
(0.001)\end{array}$ & $\begin{array}{c}0.973 \\
(0.001)\end{array}$ & $\begin{array}{c}0.966 \\
(0.004)\end{array}$ & $\begin{array}{c}0.974 \\
(0.002)\end{array}$ & $\begin{array}{c}0.974 \\
(0.002)\end{array}$ & $\begin{array}{l}-0.008 \\
(0.002)\end{array}$ & $\begin{array}{l}-0.005 \\
(0.004)\end{array}$ \\
\hline Feb95 & 23774 & $\begin{array}{c}0.980 \\
(0.001)\end{array}$ & $\begin{array}{c}0.985 \\
(0.002)\end{array}$ & $\begin{array}{c}0.977 \\
(0.002)\end{array}$ & $\begin{array}{c}0.976 \\
(0.006)\end{array}$ & $\begin{array}{c}0.976 \\
(0.002)\end{array}$ & $\begin{array}{c}0.979 \\
(0.003)\end{array}$ & $\begin{array}{l}-0.008 \\
(0.003)\end{array}$ & $\begin{array}{l}-0.006 \\
(0.002)\end{array}$ \\
\hline Feb97 & 21242 & $\begin{array}{c}0.982 \\
(0.001)\end{array}$ & $\begin{array}{c}0.990 \\
(0.002) \\
\end{array}$ & $\begin{array}{c}0.979 \\
(0.002)\end{array}$ & $\begin{array}{c}0.974 \\
(0.006)\end{array}$ & $\begin{array}{c}0.980 \\
(0.002)\end{array}$ & $\begin{array}{c}0.980 \\
(0.003)\end{array}$ & $\begin{array}{l}-0.011 \\
(0.003)\end{array}$ & $\begin{array}{l}-0.009 \\
(0.002)\end{array}$ \\
\hline All & 67762 & $\begin{array}{c}0.982 \\
(0.001)\end{array}$ & $\begin{array}{c}0.988 \\
(0.001)\end{array}$ & $\begin{array}{c}0.980 \\
(0.001)\end{array}$ & $\begin{array}{c}0.978 \\
(0.002)\end{array}$ & $\begin{array}{c}0.981 \\
(0.001)\end{array}$ & $\begin{array}{c}0.978 \\
(0.001)\end{array}$ & $\begin{array}{l}-0.008 \\
(0.001)\end{array}$ & $\begin{array}{l}-0.007 \\
(0.001)\end{array}$ \\
\hline
\end{tabular}

Note: The numbers in parentheses are standard errors. The numbers in columns 1-6 are the fraction of workers in each group who are eligible for health insurance, conditional on being in a firm that offers it, based on weighted tabulations of data from the relevant supplements to the CPS. The average difference in column 7 is computed as the difference between the health insurance eligibility rate for workers with less than four years of college (column 3 ) and the coverage rate for all workers with four years of college or more (column 2). The adjusted differences reported in column 8 are the coefficients on a less-than-four-yearsof-college dummy variable from separate OLS regressions for each year of the health insurance eligibility indicator on the less-than-college dummy variable and controls for age, education, sex, race, marital status, and the interaction of sex and marital status. The regression adjustment for the "all" sample includes survey dummy variables as well. All counts are weighted by the CPS supplement weights. The sample includes all private sector workers ages 20-64 who are not selfemployed. 
Table A10

Fraction Covered by Employer-Provided Health Insurance Conditional on Eligibility

(Takeup Rate)

by Year and Educational Attainment

Private Sector Workers Ages 20-64

Core Jobs Only

\begin{tabular}{|c|c|c|c|c|c|c|c|c|c|}
\hline \multirow[t]{2}{*}{ Year } & \multirow{2}{*}{$\begin{array}{c}\text { Sample } \\
\text { Size }\end{array}$} & \multirow{2}{*}{$\begin{array}{c}\text { All Jobs } \\
\text { Average } \\
\text { (1) }\end{array}$} & \multirow{2}{*}{$\begin{array}{c}\text { College } \\
\text { Graduates } \\
\text { (2) }\end{array}$} & \multirow{2}{*}{$\begin{array}{c}\text { Less than } 4 \\
\text { Years of } \\
\text { College } \\
\text { (3) }\end{array}$} & \multicolumn{3}{|c|}{ Less than Four Years of College (Detail) } & \multirow{2}{*}{$\begin{array}{l}\text { Noncoll.-Coll } \\
\text { Difference } \\
\text { Average } \\
\text { (7) }\end{array}$} & \multirow{2}{*}{$\begin{array}{l}\text { Noncoll.-Coll } \\
\text { Difference } \\
\text { Adjusted } \\
\text { (8) }\end{array}$} \\
\hline & & & & & $\begin{array}{c}\text { Less Than } \\
\text { High School } \\
\text { (4) }\end{array}$ & $\begin{array}{c}\text { High School } \\
\text { Graduates } \\
\text { (5) }\end{array}$ & $\begin{array}{c}\text { Some College } \\
\text { (6) }\end{array}$ & & \\
\hline May88 & 10000 & 0.926 & 0.951 & 0.918 & 0.914 & 0.918 & 0.921 & -0.033 & -0.023 \\
\hline Apr93 & 9636 & $\begin{array}{c}(0.002) \\
0.908 \\
(0.002)\end{array}$ & $\begin{array}{c}(0.004) \\
0.921 \\
(0.004)\end{array}$ & $\begin{array}{c}(0.003) \\
0.903 \\
(0.003)\end{array}$ & $\begin{array}{c}(0.007) \\
0.906 \\
(0.008)\end{array}$ & $\begin{array}{c}(0.003) \\
0.900 \\
(0.004)\end{array}$ & $\begin{array}{c}(0.005) \\
0.906 \\
(0.004)\end{array}$ & $\begin{array}{l}(0.005) \\
-0.018 \\
(0.005)\end{array}$ & $\begin{array}{l}(0.006) \\
-0.011 \\
(0.007)\end{array}$ \\
\hline Feb95 & 20615 & $\begin{array}{c}0.891 \\
(0.003)\end{array}$ & $\begin{array}{c}0.913 \\
(0.005)\end{array}$ & $\begin{array}{c}0.884 \\
(0.004)\end{array}$ & $\begin{array}{c}0.871 \\
(0.012)\end{array}$ & $\begin{array}{c}0.880 \\
(0.005)\end{array}$ & $\begin{array}{c}0.891 \\
(0.005)\end{array}$ & $\begin{array}{l}-0.029 \\
(0.007)\end{array}$ & $\begin{array}{l}-0.025 \\
(0.005)\end{array}$ \\
\hline Feb97 & 18555 & $\begin{array}{c}0.883 \\
(0.003) \\
\end{array}$ & $\begin{array}{c}0.904 \\
(0.005) \\
\end{array}$ & $\begin{array}{c}0.875 \\
(0.003) \\
\end{array}$ & $\begin{array}{c}0.868 \\
(0.012) \\
\end{array}$ & $\begin{array}{c}0.873 \\
(0.005) \\
\end{array}$ & $\begin{array}{c}0.880 \\
(0.005)\end{array}$ & $\begin{array}{l}-0.029 \\
(0.006)\end{array}$ & $\begin{array}{l}-0.027 \\
(0.005)\end{array}$ \\
\hline All & 58806 & $\begin{array}{c}0.906 \\
(0.001)\end{array}$ & $\begin{array}{c}0.925 \\
(0.002)\end{array}$ & $\begin{array}{c}0.900 \\
(0.001)\end{array}$ & $\begin{array}{c}0.899 \\
(0.004)\end{array}$ & $\begin{array}{c}0.899 \\
(0.002)\end{array}$ & $\begin{array}{c}0.902 \\
(0.002)\end{array}$ & $\begin{array}{l}-0.025 \\
(0.003)\end{array}$ & $\begin{array}{l}-0.020 \\
(0.003)\end{array}$ \\
\hline
\end{tabular}

Note: The numbers in parentheses are standard errors. The numbers in columns 1-6 are the fraction of workers in each group who are enrolled in their employer's health insurance plan, conditional on being eligible for it, based on weighted tabulations of data from the relevant supplements to the CPS. The average difference in column 7 is computed as the difference between the enrollment rate for workers with education less than four years of college (column 3 ) and the enrollment rate for workers with four years of college or more (column 2). The adjusted differences reported in column 8 are the coefficients on a lessthan-four-years-of-college dummy variable from separate OLS regressions for each year of the health insurance takeup indicator on the less-than-four-years-ofcollege dummy variable and controls for age, education, sex, race, marital status, and the interaction of sex and marital status. The regression adjustment for the "all" sample includes survey dummy variables as well. All counts are weighted by the CPS supplement weights. The sample includes all private sector workers ages 20-64 who are not self-employed. 
Table A11

Fraction of Workers with Coverage as a Dependent on a Spouse's Employer-Sponsored Health Insurance Policy (Spousal Coverage Rate)

by Year and Educational Attainment

Private Sector Workers Ages 20-64

Core Jobs Only

\begin{tabular}{|c|c|c|c|c|c|c|c|c|c|}
\hline \multirow[t]{2}{*}{ Year } & \multirow{2}{*}{$\begin{array}{c}\text { Sample } \\
\text { Size }\end{array}$} & \multirow{2}{*}{$\begin{array}{c}\text { All Jobs } \\
\text { Average } \\
\text { (1) }\end{array}$} & \multirow{2}{*}{$\begin{array}{l}\text { College } \\
\text { Graduates } \\
\text { (2) }\end{array}$} & \multirow{2}{*}{$\begin{array}{c}\text { Less than } 4 \\
\text { Years of } \\
\text { College } \\
\text { (3) }\end{array}$} & \multicolumn{3}{|c|}{ Less than Four Years of College (Detail) } & \multirow{2}{*}{$\begin{array}{l}\text { Noncoll.-Coll } \\
\text { Difference } \\
\text { Average } \\
(7)\end{array}$} & \multirow{2}{*}{$\begin{array}{c}\text { Noncoll.-Coll } \\
\text { Difference } \\
\text { Adjusted } \\
(8)\end{array}$} \\
\hline & & & & & $\begin{array}{c}\text { Less Than } \\
\text { High School } \\
\text { (4) }\end{array}$ & $\begin{array}{l}\text { High School } \\
\text { Graduates } \\
\text { (5) }\end{array}$ & $\begin{array}{c}\text { Some College } \\
\text { (6) }\end{array}$ & & \\
\hline May88 & 14737 & 0.059 & 0.046 & 0.063 & 0.042 & 0.069 & 0.063 & 0.017 & 0.015 \\
\hline & & $(0.002)$ & $(0.004)$ & $(0.002)$ & $(0.004)$ & $(0.003)$ & $(0.004)$ & $(0.004)$ & $(0.006)$ \\
\hline Apr93 & 14557 & 0.080 & 0.081 & 0.080 & 0.050 & 0.080 & 0.092 & -0.001 & -0.001 \\
\hline & & $(0.002)$ & $(0.003)$ & $(0.002)$ & $(0.005)$ & $(0.003)$ & $(0.003)$ & $(0.004)$ & $(0.006)$ \\
\hline Feb95 & 32506 & 0.080 & 0.078 & 0.080 & 0.054 & 0.083 & 0.086 & 0.002 & 0.004 \\
\hline & & $(0.002)$ & $(0.005)$ & $(0.003)$ & $(0.007)$ & $(0.004)$ & $(0.005)$ & $(0.006)$ & $(0.004)$ \\
\hline Feb97 & 28921 & 0.082 & 0.082 & 0.082 & 0.046 & 0.087 & 0.087 & -0.001 & 0.003 \\
\hline & & $(0.002)$ & $(0.005)$ & $(0.003)$ & $(0.007)$ & $(0.004)$ & $(0.005)$ & $(0.006)$ & $(0.004)$ \\
\hline All & 90721 & $\begin{array}{c}0.074 \\
(0.001)\end{array}$ & $\begin{array}{c}0.071 \\
(0.002)\end{array}$ & $\begin{array}{c}0.075 \\
(0.001)\end{array}$ & $\begin{array}{c}0.046 \\
(0.003)\end{array}$ & $\begin{array}{c}0.078 \\
(0.002)\end{array}$ & $\begin{array}{c}0.071 \\
(0.002)\end{array}$ & $\begin{array}{c}0.004 \\
(0.002)\end{array}$ & $\begin{array}{c}0.005 \\
(0.002)\end{array}$ \\
\hline
\end{tabular}

Note: The numbers in parentheses are standard errors. The numbers in columns 1-6 are the fraction of workers in each group with employer-sponsored health insurance coverage as a dependent on a spouse's policy based on weighted tabulations of data from the relevant supplements to the CPS. The average difference in column 7 is computed as the difference between the spousal health insurance coverage rate for workers with education less than four years of college (column 3 ) and the spousal coverage rate for workers with four years of college or more (column 2). The adjusted differences reported in column 8 are the coefficients on a less-than-four-year-of-college dummy variable from separate OLS regressions for each year of the spousal health insurance coverage indicator on the less-thanfour-years-of-college dummy variable and controls for age, education, sex, and race. The regression adjustment for the "all" sample includes survey dummy variables as well. All counts are weighted by the CPS supplement weights. The sample includes all private sector workers ages $20-64$ who are not self-employed. 
Table A12

Fraction of Workers with any Employer-Sponsored Health Insurance Coverage

by Year and Educational Attainment

Private Sector Workers Ages 20-64

Core Jobs Only

\begin{tabular}{|c|c|c|c|c|c|c|c|c|c|}
\hline \multirow{4}{*}{ Year } & \multirow{4}{*}{$\begin{array}{c}\text { Sample } \\
\text { Size }\end{array}$} & \multirow{4}{*}{$\begin{array}{c}\text { All Jobs } \\
\text { Average } \\
(1) \\
\end{array}$} & \multirow{4}{*}{$\begin{array}{l}\text { College } \\
\text { Graduates } \\
(2)\end{array}$} & \multirow{4}{*}{$\begin{array}{c}\text { Less than } 4 \\
\text { Years of } \\
\text { College } \\
(3)\end{array}$} & \multicolumn{3}{|c|}{ Less than Four Years of College (Detail) } & \multirow{4}{*}{$\begin{array}{c}\text { Noncoll.-Coll } \\
\text { Difference } \\
\text { Average } \\
(7)\end{array}$} & \multirow{4}{*}{$\begin{array}{l}\text { Noncoll.-Coll } \\
\text { Difference } \\
\text { Adjusted } \\
\text { (8) }\end{array}$} \\
\hline & & & & & Less Than & High School & Some College & & \\
\hline & & & & & High School & Graduates & & & \\
\hline & & & & & (4) & (5) & (6) & & \\
\hline \multirow[t]{2}{*}{ May88 } & 14737 & 0.870 & 0.947 & 0.947 & 0.757 & 0.863 & 0.884 & -0.097 & -0.085 \\
\hline & & $(0.002)$ & $(0.004)$ & $(0.004)$ & (0.009) & $(0.004)$ & $(0.005)$ & $(0.006)$ & $(0.008)$ \\
\hline \multirow[t]{2}{*}{ Apr93 } & 14557 & 0.850 & 0.938 & 0.938 & 0.649 & 0.834 & 0.868 & -0.115 & -0.105 \\
\hline & & $(0.002)$ & $(0.003)$ & $(0.003)$ & $(0.011)$ & $(0.004)$ & $(0.004)$ & $(0.006)$ & $(0.008)$ \\
\hline \multirow[t]{2}{*}{ Feb95 } & 32506 & 0.850 & 0.931 & 0.931 & 0.666 & 0.821 & 0.877 & -0.107 & -0.098 \\
\hline & & $(0.003)$ & $(0.004)$ & $(0.004)$ & $(0.015)$ & $(0.006)$ & $(0.006)$ & $(0.008)$ & $(0.005)$ \\
\hline \multirow[t]{2}{*}{ Feb97 } & 28921 & 0.853 & 0.934 & 0.934 & 0.660 & 0.829 & 0.877 & -0.107 & -0.097 \\
\hline & & $(0.003)$ & $(0.004)$ & $(0.004)$ & $(0.015)$ & $(0.006)$ & $(0.006)$ & $(0.007)$ & $(0.006)$ \\
\hline \multirow[t]{2}{*}{ All } & 90721 & 0.857 & 0.938 & 0.832 & 0.696 & 0.841 & 0.875 & -0.106 & -0.133 \\
\hline & & $(0.001)$ & $(0.002)$ & $(0.002)$ & $(0.006)$ & $(0.002)$ & $(0.002)$ & $(0.003)$ & $(0.003)$ \\
\hline
\end{tabular}

Note: The numbers in parentheses are standard errors. The numbers in columns 1-6 are the fraction of workers in each group with employer-sponsored health insurance coverage as a dependent on a spouse's policy based on weighted tabulations of data from the relevant supplements to the CPS. The average difference in column 7 is computed as the difference between the rate of employer-sponsored health insurance coverage from any source for workers with education less than four years of college (column 3) and the coverage rate for workers with four years of college or more (column 2). The adjusted differences reported in column 8 are the coefficients on a less-than-four-years-of-college dummy variable from separate OLS regressions for each year of the health insurance coverage indicator on the less-than-four-years-of-college dummy variable and controls for age, education, sex, and race. The regression adjustment for the "all" sample includes survey dummy variables as well. All counts are weighted by the CPS supplement weights. The sample includes all private sector workers ages 20-64 who are not self-employed. 
Table A13

Employment Distribution across Educational Attainment Categories

By Year

Private Sector Workers Ages 20-64

Core Jobs Only

\begin{tabular}{l|r|cccc|c} 
Year & $\mathrm{N}$ & $\begin{array}{c}\text { Less Than } \\
\text { High } \\
\text { School } \\
(1)\end{array}$ & $\begin{array}{c}\text { High } \\
\text { School } \\
\text { Graduates } \\
(2)\end{array}$ & $\begin{array}{c}\text { Less than } \\
\text { 4 Years of } \\
\text { College } \\
(3)\end{array}$ & $\begin{array}{c}\text { College } \\
\text { Graduates }\end{array}$ & Total \\
\hline May79 & 14406 & 0.213 & 0.445 & 0.184 & 0.155 & 1.000 \\
Jan83 & 8543 & 0.177 & 0.430 & 0.200 & 0.193 & 1.000 \\
May83 & 15722 & 0.167 & 0.439 & 0.192 & 0.202 & 1.000 \\
Jan87 & 9079 & 0.155 & 0.443 & 0.205 & 0.197 & 1.000 \\
May88 & 14901 & 0.140 & 0.439 & 0.207 & 0.215 & 1.000 \\
Jan91 & 8919 & 0.123 & 0.425 & 0.224 & 0.228 & 1.000 \\
Apr93 & 14763 & 0.108 & 0.375 & 0.283 & 0.234 & 1.000 \\
Feb95 & 31066 & 0.095 & 0.365 & 0.290 & 0.248 & 1.000 \\
Feb96 & 25166 & 0.109 & 0.362 & 0.290 & 0.239 & 1.000 \\
Feb97 & 27480 & 0.094 & 0.369 & 0.287 & 0.250 & 1.000 \\
\hline All & 170045 & 0.135 & 0.408 & 0.239 & 0.218 & 1.000
\end{tabular}

Note: The numbers in columns 1-4 are the fraction of workers in each group based on weighted tabulations of data from the relevant supplements to the CPS. All counts are weighted by the CPS final sampling weights. Self-employed workers and workers with missing data on tenure or hours of work are not included in the analysis. Incorporated self-employed workers are included in May 1979. The sample includes workers aged 20-64 only. 
Table A14

Fraction Covered by Health Insurance Provided by Their Employer by Year and Educational Attainment Private Sector Workers Ages 20-64 Peripheral Jobs Only

\begin{tabular}{|c|c|c|c|c|c|c|c|c|c|}
\hline \multirow{2}{*}{ Year } & \multirow{2}{*}{$\begin{array}{c}\text { Sample } \\
\text { Size }\end{array}$} & \multirow{2}{*}{$\begin{array}{c}\text { All Jobs } \\
\text { Average } \\
\text { (1) }\end{array}$} & \multirow{2}{*}{$\begin{array}{l}\text { College } \\
\text { Graduates } \\
\text { (2) }\end{array}$} & \multirow{2}{*}{$\begin{array}{l}\text { Less than } 4 \\
\text { Years of } \\
\text { College } \\
\text { (3) }\end{array}$} & \multicolumn{3}{|c|}{ Less than Four Years of College (Detail) } & \multirow{2}{*}{$\begin{array}{c}\text { Noncoll.-Coll } \\
\text { Difference } \\
\text { Average } \\
(7)\end{array}$} & \multirow{2}{*}{$\begin{array}{c}\text { Noncoll.-Coll } \\
\text { Difference } \\
\text { Adjusted } \\
\text { (8) }\end{array}$} \\
\hline & & & & & $\begin{array}{c}\text { Less Than } \\
\text { High School } \\
(4)\end{array}$ & $\begin{array}{c}\text { High School } \\
\text { Graduates } \\
(5)\end{array}$ & $\begin{array}{c}\text { Some College } \\
(6) \\
\end{array}$ & & \\
\hline May79 & 4647 & 0.454 & 0.574 & 0.434 & 0.401 & 0.431 & 0.467 & -0.140 & -0.102 \\
\hline & & $(0.006)$ & $(0.016)$ & $(0.006)$ & $(0.014)$ & $(0.009)$ & $(0.012)$ & $(0.017)$ & $(0.020)$ \\
\hline May83 & 4841 & 0.376 & 0.535 & 0.344 & 0.274 & 0.361 & 0.363 & -0.191 & -0.167 \\
\hline & & $(0.006)$ & $(0.014)$ & $(0.006)$ & $(0.014)$ & $(0.009)$ & $(0.011)$ & $(0.015)$ & $(0.018)$ \\
\hline May88 & 4686 & 0.396 & 0.578 & 0.357 & 0.283 & 0.366 & 0.387 & -0.221 & -0.202 \\
\hline & & $(0.005)$ & $(0.013)$ & $(0.006)$ & $(0.014)$ & $(0.008)$ & $(0.011)$ & $(0.014)$ & $(0.018)$ \\
\hline Apr93 & 4353 & 0.325 & 0.501 & 0.283 & 0.199 & 0.278 & 0.319 & -0.218 & -0.203 \\
\hline & & $(0.005)$ & $(0.013)$ & $(0.006)$ & $(0.016)$ & (0.009) & (0.009) & $(0.014)$ & $(0.018)$ \\
\hline Feb95 & 9919 & 0.333 & 0.497 & 0.290 & 0.208 & 0.298 & 0.306 & -0.207 & -0.198 \\
\hline & & $(0.007)$ & $(0.016)$ & $(0.008)$ & $(0.023)$ & $(0.013)$ & $(0.012)$ & $(0.018)$ & $(0.012)$ \\
\hline Feb97 & 8761 & 0.341 & 0.506 & 0.295 & 0.250 & 0.284 & 0.318 & -0.211 & -0.196 \\
\hline & & $(0.007)$ & $(0.016)$ & $(0.008)$ & $(0.023)$ & $(0.013)$ & $(0.012)$ & $(0.018)$ & $(0.012)$ \\
\hline All & 37207 & $\begin{array}{c}0.374 \\
(0.003)\end{array}$ & $\begin{array}{c}0.533 \\
(0.006)\end{array}$ & $\begin{array}{c}0.339 \\
(0.003)\end{array}$ & $\begin{array}{c}0.285 \\
(0.007)\end{array}$ & $\begin{array}{c}0.346 \\
(0.004)\end{array}$ & $\begin{array}{c}0.356 \\
(0.004)\end{array}$ & $\begin{array}{l}-0.194 \\
(0.006)\end{array}$ & $\begin{array}{l}-0.182 \\
(0.006)\end{array}$ \\
\hline
\end{tabular}

Note: The numbers in parentheses are standard errors. The numbers in columns 1-6 are the fraction of workers in each group reporting that they are covered by their own employer-provided health insurance based on weighted tabulations of data from the relevant supplements to the CPS. The average difference in column 7 is computed as the difference between the health insurance coverage rate for workers with less than four years of college (column 3 ) and the coverage rate for all workers with four years of college or more (column 2). The adjusted differences reported in column 8 are the coefficients on a less-than-four-years-of-college dummy variable from separate OLS regressions for each year of the health insurance coverage indicator on the less-than-college dummy variable and controls for age, education, sex, race, marital status, and the interaction of sex and marital status. The regression adjustment for the "all" sample includes survey dummy

variables as well. All counts are weighted by the CPS supplement weights. The sample includes all private sector workers ages $20-64$ who are not self-employed. 
Table A15

Fraction Whose Employers Offer Health Insurance Coverage to at least Some Employees

by Year and Educational Attainment

Private Sector Workers Ages 20-64

Peripheral Jobs Only

\begin{tabular}{|c|c|c|c|c|c|c|c|c|c|}
\hline \multirow{2}{*}{ Year } & \multirow{2}{*}{\begin{tabular}{|} 
Sample \\
Size
\end{tabular}} & \multirow{2}{*}{$\begin{array}{c}\text { All Jobs } \\
\text { Average } \\
(1)\end{array}$} & \multirow{2}{*}{$\begin{array}{c}\text { College } \\
\text { Graduates } \\
(2)\end{array}$} & \multirow{2}{*}{$\begin{array}{c}\text { Less than } 4 \\
\text { Years of } \\
\text { College } \\
\text { (3) }\end{array}$} & \multicolumn{3}{|c|}{ Less than Four Years of College (Detail) } & \multirow{2}{*}{$\begin{array}{c}\text { Noncoll.-Coll } \\
\text { Difference } \\
\text { Average } \\
(7) \\
\end{array}$} & \multirow{2}{*}{$\begin{array}{l}\text { Noncoll.-Coll } \\
\text { Difference } \\
\text { Adjusted } \\
\text { (8) }\end{array}$} \\
\hline & & & & & $\begin{array}{c}\text { Less Than } \\
\text { High School } \\
\text { (4) }\end{array}$ & $\begin{array}{l}\text { High School } \\
\text { Graduates } \\
\text { (5) }\end{array}$ & $\begin{array}{c}\text { Some College } \\
\text { (6) }\end{array}$ & & \\
\hline May88 & 4705 & 0.682 & 0.828 & 0.650 & 0.519 & 0.665 & 0.706 & -0.178 & -0.164 \\
\hline & & $(0.005)$ & $(0.009)$ & $(0.006)$ & $(0.014)$ & $(0.008)$ & $(0.009)$ & $(0.013)$ & $(0.018)$ \\
\hline Apr93 & 4364 & 0.005 & 0.783 & 0.601 & 0.407 & 0.594 & 0.677 & -0.182 & -0.178 \\
\hline & & $(0.005)$ & $(0.009)$ & $(0.006)$ & $(0.017)$ & $(0.009)$ & $(0.008)$ & $(0.013)$ & $(0.019)$ \\
\hline Feb95 & 9919 & 0.688 & 0.826 & 0.652 & 0.489 & 0.656 & 0.694 & -0.173 & -0.169 \\
\hline & & $(0.007)$ & $(0.012)$ & $(0.008)$ & $(0.024)$ & $(0.012)$ & $(0.011)$ & $(0.017)$ & $(0.011)$ \\
\hline Feb97 & 8761 & 0.703 & 0.821 & 0.670 & 0.517 & 0.659 & 0.724 & -0.152 & -0.148 \\
\hline & & $(0.007)$ & $(0.012)$ & $(0.008)$ & $(0.024)$ & $(0.012)$ & $(0.011)$ & $(0.016)$ & $(0.012)$ \\
\hline All & 27749 & $\begin{array}{c}0.672 \\
(0.003)\end{array}$ & $\begin{array}{c}0.812 \\
(0.005)\end{array}$ & $\begin{array}{c}0.638 \\
(0.003)\end{array}$ & $\begin{array}{c}0.480 \\
(0.009)\end{array}$ & $\begin{array}{c}0.640 \\
(0.005)\end{array}$ & $\begin{array}{c}0.697 \\
(0.005)\end{array}$ & $\begin{array}{l}-0.174 \\
(0.007)\end{array}$ & $\begin{array}{l}-0.166 \\
(0.007)\end{array}$ \\
\hline
\end{tabular}

Note: The numbers in parentheses are standard errors. The numbers in columns 1-6 are the fraction of workers in each group who are in a firm that offers health insurance to at least some workers in the firm based on weighted tabulations of data from the relevant supplements to the CPS. The average difference in column 7 is computed as the difference between the health insurance offering rate for workers with less than four year of college (column 3) and the offering rate for all workers with four years of college or more (column 2). The adjusted differences reported in column 8 are the coefficients on a less-than-four-years-of-college dummy variable from separate OLS regressions for each year of the health insurance offering indicator on the less-than-college dummy variable and controls for age, education, sex, race, marital status, and the interaction of sex and marital status. The regression adjustment for the "all" sample includes survey dummy variables as well. All counts are weighted by the CPS supplement weights. The sample includes all private sector workers ages 20-64 who are not self-employed. 
Table A16

Fraction Eligible for Health Insurance Coverage Conditional on Employer Offering by Year and Educational Attainment

Private Sector Workers Ages 20-64

Peripheral Jobs Only

\begin{tabular}{|c|c|c|c|c|c|c|c|c|c|}
\hline \multirow{4}{*}{ Year } & \multirow{4}{*}{\begin{tabular}{|} 
Sample \\
Size
\end{tabular}} & \multirow{4}{*}{$\begin{array}{c}\text { All Jobs } \\
\text { Average } \\
(1)\end{array}$} & \multirow{4}{*}{$\begin{array}{c}\text { College } \\
\text { Graduates } \\
(2)\end{array}$} & \multirow{4}{*}{$\begin{array}{l}\text { Less than } 4 \\
\text { Years of } \\
\text { College } \\
\text { (3) }\end{array}$} & \multicolumn{3}{|c|}{ Less than Four Years of College (Detail) } & \multirow{4}{*}{$\begin{array}{c}\text { Noncoll.-Coll } \\
\text { Difference } \\
\text { Average } \\
(7) \\
\end{array}$} & \multirow{4}{*}{$\begin{array}{l}\text { Noncoll.-Coll } \\
\text { Difference } \\
\text { Adjusted } \\
\text { (8) }\end{array}$} \\
\hline & & & & & Less Than & High School & Some College & & \\
\hline & & & & & High School & Graduates & & & \\
\hline & & & & & (4) & (5) & (6) & & \\
\hline \multirow[t]{2}{*}{ May88 } & 4705 & 0.798 & 0.888 & 0.774 & 0.773 & 0.769 & 0.781 & -0.115 & -0.103 \\
\hline & & $(0.006)$ & $(0.010)$ & $(0.006)$ & $(0.018)$ & $(0.009)$ & $(0.011)$ & $(0.013)$ & $(0.017)$ \\
\hline \multirow[t]{2}{*}{ Apr93 } & 4364 & 0.710 & 0.785 & 0.687 & 0.713 & 0.685 & 0.684 & -0.098 & -0.085 \\
\hline & & $(0.006)$ & $(0.010)$ & $(0.007)$ & $(0.023)$ & $(0.010)$ & $(0.001)$ & $(0.014)$ & $(0.020)$ \\
\hline \multirow[t]{2}{*}{ Feb95 } & 9837 & 0.702 & 0.789 & 0.673 & 0.669 & 0.668 & 0.678 & -0.116 & -0.103 \\
\hline & & $(0.008)$ & $(0.013)$ & $(0.009)$ & $(0.030)$ & $(0.014)$ & $(0.013)$ & $(0.018)$ & $(0.013)$ \\
\hline \multirow[t]{2}{*}{ Feb97 } & 8698 & 0.696 & 0.801 & 0.660 & 0.674 & 0.658 & 0.658 & -0.141 & -0.118 \\
\hline & & $(0.007)$ & $(0.013)$ & $(0.009)$ & $(0.030)$ & $(0.014)$ & $(0.013)$ & $(0.017)$ & $(0.013)$ \\
\hline \multirow[t]{2}{*}{ All } & 27604 & $\begin{array}{c}0.735 \\
(0.003)\end{array}$ & $\begin{array}{c}0.821 \\
(0.006)\end{array}$ & $\begin{array}{c}0.709 \\
(0.004)\end{array}$ & $\begin{array}{c}0.727 \\
(0.012)\end{array}$ & $\begin{array}{c}0.711 \\
(0.006)\end{array}$ & $\begin{array}{c}0.703 \\
(0.006)\end{array}$ & -0.112 & $\begin{array}{l}-0.101 \\
(0008)\end{array}$ \\
\hline & & $(0.003)$ & (0.000) & (0.004) & $(0.012)$ & $(0.006)$ & $(0.006)$ & (0.008) & \\
\hline
\end{tabular}

Note: The numbers in parentheses are standard errors. The numbers in columns 1-6 are the fraction of workers in each group who are eligible for health insurance, conditional on being in a firm that offers it, based on weighted tabulations of data from the relevant supplements to the CPS. The average difference in column 7 is computed as the difference between the health insurance eligibility rate for workers with less than four years of college (column 3 ) and the coverage rate for all workers with four years of college or more (column 2). The adjusted differences reported in column 8 are the coefficients on a less-than-four-yearsof-college dummy variable from separate OLS regressions for each year of the health insurance eligibility indicator on the less-than-college dummy variable and controls for age, education, sex, race, marital status, and the interaction of sex and marital status. The regression adjustment for the "all" sample includes survey dummy variables as well. All counts are weighted by the CPS supplement weights. The sample includes all private sector workers ages 20-64 who are not selfemployed. 
Table A17

Fraction Covered by Employer-Provided Health Insurance Conditional on Eligibility (Takeup Rate)

by Year and Educational Attainment

Private Sector Workers Ages 20-64

Peripheral Jobs Only

\begin{tabular}{|c|c|c|c|c|c|c|c|c|c|}
\hline \multirow[t]{2}{*}{ Year } & \multirow{2}{*}{$\begin{array}{c}\text { Sample } \\
\text { Size }\end{array}$} & \multirow{2}{*}{$\begin{array}{c}\text { All Jobs } \\
\text { Average } \\
\text { (1) }\end{array}$} & \multirow{2}{*}{$\begin{array}{c}\text { College } \\
\text { Graduates } \\
\text { (2) }\end{array}$} & \multirow{2}{*}{$\begin{array}{c}\text { Less than } 4 \\
\text { Years of } \\
\text { College } \\
\text { (3) }\end{array}$} & \multicolumn{3}{|c|}{ Less than Four Years of College (Detail) } & \multirow{2}{*}{$\begin{array}{l}\text { Noncoll.-Coll } \\
\text { Difference } \\
\text { Average } \\
\text { (7) }\end{array}$} & \multirow{2}{*}{$\begin{array}{l}\text { Noncoll.-Coll } \\
\text { Difference } \\
\text { Adjusted } \\
\text { (8) }\end{array}$} \\
\hline & & & & & $\begin{array}{c}\text { Less Than } \\
\text { High School } \\
(4)\end{array}$ & $\begin{array}{c}\text { High School } \\
\text { Graduates } \\
(5)\end{array}$ & $\begin{array}{c}\text { Some College } \\
\text { (6) }\end{array}$ & & \\
\hline May88 & 2548 & 0.731 & 0.787 & 0.714 & 0.711 & 0.717 & 0.709 & -0.074 & -0.054 \\
\hline & & $(0.006)$ & $(0.012)$ & $(0.008)$ & $(0.021)$ & $(0.011)$ & $(0.013)$ & $(0.017)$ & $(0.020)$ \\
\hline Apr93 & 1986 & $\begin{array}{c}0.722 \\
(0.007)\end{array}$ & $\begin{array}{c}0.816 \\
(0.012)\end{array}$ & $\begin{array}{c}0.689 \\
(0.009)\end{array}$ & $\begin{array}{c}0.695 \\
(0.029)\end{array}$ & $\begin{array}{c}0.686 \\
(0.013)\end{array}$ & $\begin{array}{c}0.691 \\
(0.012)\end{array}$ & $\begin{array}{l}-0.127 \\
(0.016)\end{array}$ & $\begin{array}{l}-0.107 \\
(0.022)\end{array}$ \\
\hline Feb95 & 4725 & $\begin{array}{c}0.698 \\
(0.009)\end{array}$ & $\begin{array}{c}0.776 \\
(0.016)\end{array}$ & $\begin{array}{c}0.668 \\
(0.011)\end{array}$ & $\begin{array}{c}0.641 \\
(0.039)\end{array}$ & $\begin{array}{c}0.685 \\
(0.018)\end{array}$ & $\begin{array}{c}0.658 \\
(0.016)\end{array}$ & $\begin{array}{l}-0.108 \\
(0.021)\end{array}$ & $\begin{array}{l}-0.100 \\
(0.015)\end{array}$ \\
\hline Feb97 & 4246 & $\begin{array}{c}0.705 \\
(0.009) \\
\end{array}$ & $\begin{array}{c}0.778 \\
(0.015) \\
\end{array}$ & $\begin{array}{c}0.675 \\
(0.011) \\
\end{array}$ & $\begin{array}{c}0.714 \\
(0.038) \\
\end{array}$ & $\begin{array}{c}0.662 \\
(0.018) \\
\end{array}$ & $\begin{array}{c}0.676 \\
(0.016) \\
\end{array}$ & $\begin{array}{l}-0.104 \\
(0.020)\end{array}$ & $\begin{array}{l}-0.090 \\
(0.015)\end{array}$ \\
\hline All & 13505 & $\begin{array}{c}0.718 \\
(0.004)\end{array}$ & $\begin{array}{c}0.792 \\
(0.007)\end{array}$ & $\begin{array}{c}0.692 \\
(0.005)\end{array}$ & $\begin{array}{c}0.699 \\
(0.014)\end{array}$ & $\begin{array}{c}0.695 \\
(0.007)\end{array}$ & $\begin{array}{c}0.687 \\
(0.007)\end{array}$ & $\begin{array}{l}-0.100 \\
(0.009)\end{array}$ & $\begin{array}{l}-0.085 \\
(0.009)\end{array}$ \\
\hline
\end{tabular}

Note: The numbers in parentheses are standard errors. The numbers in columns 1-6 are the fraction of workers in each group who are enrolled in their employer's health insurance plan, conditional on being eligible for it, based on weighted tabulations of data from the relevant supplements to the CPS. The average difference in column 7 is computed as the difference between the enrollment rate for workers with education less than four years of college (column 3 ) and the enrollment rate for workers with four years of college or more (column 2). The adjusted differences reported in column 8 are the coefficients on a lessthan-four-years-of-college dummy variable from separate OLS regressions for each year of the health insurance takeup indicator on the less-than-four-years-ofcollege dummy variable and controls for age, education, sex, race, marital status, and the interaction of sex and marital status. The regression adjustment for the "all" sample includes survey dummy variables as well. All counts are weighted by the CPS supplement weights. The sample includes all private sector workers ages 20-64 who are not self-employed. 
Table A18

Fraction of Workers with Coverage as a Dependent on a Spouse's Employer-Sponsored Health Insurance Policy (Spousal Coverage Rate)

by Year and Educational Attainment

Private Sector Workers Ages 20-64

Peripheral Jobs Only

\begin{tabular}{|c|c|c|c|c|c|c|c|c|c|}
\hline \multirow[t]{2}{*}{ Year } & \multirow{2}{*}{$\begin{array}{c}\text { Sample } \\
\text { Size }\end{array}$} & \multirow{2}{*}{$\begin{array}{c}\text { All Jobs } \\
\text { Average } \\
(1) \\
\end{array}$} & \multirow{2}{*}{$\begin{array}{c}\text { College } \\
\text { Graduates } \\
\text { (2) }\end{array}$} & \multirow{2}{*}{$\begin{array}{c}\text { Less than } 4 \\
\text { Years of } \\
\text { College } \\
\text { (3) }\end{array}$} & \multicolumn{3}{|c|}{ Less than Four Years of College (Detail) } & \multirow{2}{*}{$\begin{array}{l}\text { Noncoll.-Coll } \\
\text { Difference } \\
\text { Average } \\
\text { (7) }\end{array}$} & \multirow{2}{*}{$\begin{array}{l}\text { Noncoll.-Coll } \\
\text { Difference } \\
\text { Adjusted } \\
\text { (8) }\end{array}$} \\
\hline & & & & & $\begin{array}{c}\text { Less Than } \\
\text { High School } \\
\text { (4) }\end{array}$ & $\begin{array}{l}\text { High School } \\
\text { Graduates } \\
\text { (5) }\end{array}$ & $\begin{array}{c}\text { Some College } \\
\text { (6) }\end{array}$ & & \\
\hline May88 & 4270 & 0.177 & 0.189 & 0.174 & 0.126 & 0.196 & 0.167 & -0.015 & 0.006 \\
\hline & & $(0.004)$ & $(0.010)$ & $(0.005)$ & $(0.009)$ & $(0.007)$ & $(0.008)$ & $(0.011)$ & $(0.015)$ \\
\hline Apr93 & 3998 & 0.178 & 0.196 & 0.174 & 0.089 & 0.190 & 0.188 & -0.022 & -0.001 \\
\hline & & $(0.004)$ & $(0.010)$ & $(0.005)$ & $(0.010)$ & $(0.007)$ & $(0.007)$ & $(0.011)$ & $(0.015)$ \\
\hline Feb95 & 9561 & 0.171 & 0.205 & 0.163 & 0.077 & 0.179 & 0.172 & -0.042 & -0.022 \\
\hline & & $(0.006)$ & $(0.012)$ & $(0.006)$ & $(0.015)$ & $(0.010)$ & $(0.009)$ & $(0.014)$ & $(0.009)$ \\
\hline Feb97 & 8418 & 0.175 & 0.202 & 0.168 & 0.089 & 0.187 & 0.172 & -0.034 & -0.017 \\
\hline All & 26247 & $\frac{(0.006)}{0.176}$ & $\frac{(0.012)}{0.197}$ & $\frac{(0.000)}{0.171}$ & $\frac{(0.015)}{0.102}$ & $\frac{(0.010)}{0.190}$ & $\frac{(0.009)}{0.176}$ & $\frac{(0.013)}{-0.026}$ & $\frac{(0.010)}{-0.006}$ \\
\hline & & $(0.002)$ & $(0.005)$ & $(0.003)$ & $(0.006)$ & $(0.004)$ & $(0.004)$ & $(0.006)$ & $(0.006)$ \\
\hline
\end{tabular}

Note: The numbers in parentheses are standard errors. The numbers in columns 1-6 are the fraction of workers in each group with employer-sponsored health insurance coverage as a dependent on a spouse's policy based on weighted tabulations of data from the relevant supplements to the CPS. The average difference in column 7 is computed as the difference between the spousal health insurance coverage rate for workers with education less than four years of college (column 3 ) and the spousal coverage rate for workers with four years of college or more (column 2). The adjusted differences reported in column 8 are the coefficients on a less-than-four-year-of-college dummy variable from separate OLS regressions for each year of the spousal health insurance coverage indicator on the less-thanfour-years-of-college dummy variable and controls for age, education, sex, and race. The regression adjustment for the "all" sample includes survey dummy variables as well. All counts are weighted by the CPS supplement weights. The sample includes all private sector workers ages 20-64 who are not self-employed. 
Table A19

Fraction of Workers with any Employer-Sponsored Health Insurance Coverage

by Year and Educational Attainment

Private Sector Workers Ages 20-64

Peripheral Jobs Only

\begin{tabular}{|c|c|c|c|c|c|c|c|c|c|}
\hline \multirow{4}{*}{ Year } & \multirow{4}{*}{\begin{tabular}{|} 
Sample \\
Size
\end{tabular}} & \multirow{4}{*}{$\begin{array}{c}\text { All Jobs } \\
\text { Average } \\
(1)\end{array}$} & \multirow{4}{*}{$\begin{array}{c}\text { College } \\
\text { Graduates } \\
(2)\end{array}$} & \multirow{4}{*}{$\begin{array}{c}\text { Less than } 4 \\
\text { Years of } \\
\text { College } \\
(3)\end{array}$} & \multicolumn{3}{|c|}{ Less than Four Years of College (Detail) } & \multirow{4}{*}{$\begin{array}{c}\text { Noncoll.-Coll } \\
\text { Difference } \\
\text { Average } \\
(7) \\
\end{array}$} & \multirow{4}{*}{$\begin{array}{l}\text { Noncoll.-Coll } \\
\text { Difference } \\
\text { Adjusted } \\
\text { (8) }\end{array}$} \\
\hline & & & & & Less Than & High School & Some College & & \\
\hline & & & & & High School & Graduates & & & \\
\hline & & & & & (4) & (5) & (6) & & \\
\hline \multirow{2}{*}{ May88 } & 4270 & 0.575 & 0.787 & 0.530 & 0.401 & 0.565 & 0.553 & -0.257 & -0.220 \\
\hline & & $(0.005)$ & $(0.011)$ & $(0.006)$ & $(0.014)$ & $(0.008)$ & $(0.011)$ & $(0.014)$ & $(0.019)$ \\
\hline \multirow[t]{2}{*}{ Apr93 } & 3998 & 0.503 & 0.701 & 0.457 & 0.290 & 0.470 & 0.503 & -0.244 & -0.212 \\
\hline & & $(0.005)$ & $(0.011)$ & $(0.006)$ & $(0.016)$ & $(0.009)$ & $(0.009)$ & $(0.014)$ & $(0.019)$ \\
\hline \multirow[t]{2}{*}{ Feb95 } & 9561 & 0.505 & 0.707 & 0.453 & 0.279 & 0.478 & 0.479 & -0.254 & -0.224 \\
\hline & & $(0.007)$ & $(0.014)$ & $(0.008)$ & $(0.023)$ & $(0.013)$ & $(0.012)$ & $(0.018)$ & $(0.012)$ \\
\hline \multirow[t]{2}{*}{ Feb97 } & 8418 & 0.519 & 0.713 & 0.464 & 0.340 & 0.472 & 0.492 & -0.248 & -0.217 \\
\hline & & $(0.007)$ & $(0.013)$ & $(0.008)$ & $(0.024)$ & $(0.013)$ & $(0.012)$ & $(0.017)$ & $(0.013)$ \\
\hline \multirow[t]{2}{*}{ All } & 26247 & $\begin{array}{c}0.529 \\
(0.003)\end{array}$ & $\begin{array}{c}0.730 \\
(0.006)\end{array}$ & $\begin{array}{c}0.481 \\
(0.003)\end{array}$ & $\begin{array}{c}0.340 \\
(0.009)\end{array}$ & $\begin{array}{c}0.507 \\
(0.005)\end{array}$ & $\begin{array}{c}0.508 \\
(0.005)\end{array}$ & $\begin{array}{l}-0.248 \\
(0.008)\end{array}$ & $\begin{array}{l}-0.218 \\
(0.008)\end{array}$ \\
\hline & & $(0.003)$ & (0.000) & (0.003) & (0.009) & (0.005) & & (0.008) & \\
\hline
\end{tabular}

Note: The numbers in parentheses are standard errors. The numbers in columns 1-6 are the fraction of workers in each group with employer-sponsored health insurance coverage as a dependent on a spouse's policy based on weighted tabulations of data from the relevant supplements to the CPS. The average difference in column 7 is computed as the difference between the rate of employer-sponsored health insurance coverage from any source for workers with education less than four years of college (column 3) and the coverage rate for workers with four years of college or more (column 2). The adjusted differences reported in column 8 are the coefficients on a less-than-four-years-of-college dummy variable from separate OLS regressions for each year of the health insurance coverage indicator on the less-than-four-years-of-college dummy variable and controls for age, education, sex, and race. The regression adjustment for the "all" sample includes survey dummy variables as well. All counts are weighted by the CPS supplement weights. The sample includes all private sector workers ages 20-64 who are not self-employed. 
Table A20

Employment Distribution across Educational Attainment Categories

By Year

Private Sector Workers Ages 20-64

Peripheral Jobs Only

\begin{tabular}{l|r|cccc|c} 
Year & $\mathrm{N}$ & $\begin{array}{c}\text { Less Than } \\
\text { High } \\
\text { School } \\
(1)\end{array}$ & $\begin{array}{c}\text { High } \\
\text { School } \\
\text { Graduates } \\
(2)\end{array}$ & $\begin{array}{c}\text { Less than } \\
\text { 4 Years of } \\
\text { College } \\
(3)\end{array}$ & $\begin{array}{c}\text { College } \\
\text { Graduates }\end{array}$ & Total \\
\hline May79 & 5711 & 0.195 & 0.435 & 0.227 & 0.143 & 1.000 \\
Jan83 & 3729 & 0.156 & 0.410 & 0.249 & 0.186 & 1.000 \\
May83 & 5778 & 0.175 & 0.416 & 0.241 & 0.169 & 1.000 \\
Jan87 & 3694 & 0.166 & 0.417 & 0.254 & 0.164 & 1.000 \\
May88 & 5857 & 0.157 & 0.425 & 0.246 & 0.171 & 1.000 \\
Jan91 & 3522 & 0.137 & 0.402 & 0.266 & 0.196 & 1.000 \\
Apr93 & 5533 & 0.133 & 0.347 & 0.335 & 0.185 & 1.000 \\
Feb95 & 12462 & 0.105 & 0.326 & 0.366 & 0.203 & 1.000 \\
Feb96 & 10096 & 0.118 & 0.334 & 0.347 & 0.202 & 1.000 \\
Feb97 & 10942 & 0.101 & 0.339 & 0.347 & 0.213 & 1.000 \\
\hline All & 67324 & 0.142 & 0.383 & 0.291 & 0.185 & 1.000
\end{tabular}

Note: The numbers in columns 1-4 are the fraction of workers in each group based on weighted tabulations of data from the relevant supplements to the CPS. All counts are weighted by the CPS final sampling weights. Self-employed workers and workers with missing data on tenure or hours of work are not included in the analysis. Incorporated self-employed workers are included in May 1979. The sample includes workers aged 20-64 only. 